\title{
Evaluation of Nitrogen-Rich Macrocyclic Ligands for the Chelation of Therapeutic Bismuth Radioisotopes
}

Justin J. Wilson, * Maryline Ferrier, Valery Radchenko, Joel R. Maassen, Jonathan W. Engle, Enrique R. Batista, Richard L. Martin, Francois M. Nortier, Michael E. Fassbender, Kevin D. John, Eva R. Birnbaum*

Los Alamos National Laboratory, P.O. Box 1663, Los Alamos, NM, 87545, USA

\begin{abstract}
Introduction: The use of $\alpha$-emitting isotopes for radionuclide therapy is a promising treatment strategy for small micro-metastatic disease. The radioisotope ${ }^{213} \mathrm{Bi}$ is a nuclide that has found substantial use for targeted $\alpha$-therapy (TAT). The relatively unexplored aqueous chemistry of $\mathrm{Bi}^{3+}$, however, hinders the development of bifunctional chelating agents that can successfully deliver these $\mathrm{Bi}$ radioisotopes to the tumor cells. Here, a novel series of nitrogen-rich macrocyclic ligands is explored for their potential use as Bi-selective chelating agents. Methods: The ligands, 1,4,7,10-tetrakis(pyridin-2-ylmethyl)-1,4,7,10-tetraazacyclododecane $\left(\mathrm{L}^{\mathrm{py}}\right), 1,4,7,10$-tetrakis(3-pyridazylmethyl)-1,4,7,10-tetraazacyclododecane $\left(\mathrm{L}^{\mathrm{pyd}}\right), 1,4,7,10$ tetrakis(4-pyrimidylmethyl)-1,4,7,10-tetraazacyclododecane $\left(\mathrm{L}^{\mathrm{pyr}}\right)$, and 1,4,7,10-tetrakis(2pyrazinylmethyl)-1,4,7,10-tetraazacyclododecane $\left(\mathrm{L}^{\mathrm{pz}}\right)$, were prepared by a previously reported method and investigated here for their abilities to bind $\mathrm{Bi}$ radioisotopes. The commercially available and commonly used ligands 1,4,7,10-tetraazacyclododecane-1,4,7,10-tetraacetic acid (DOTA) and $N$-[(R)-2-amino-3-(p-isothiocyanato-phenyl)propyl]-trans- $(S, S)$ cyclohexane-1,2-diamine- $N, N, N^{\prime}, N^{\prime \prime}, N^{\prime \prime}$-pentaacetic acid (CHX-A"-DTPA) were also explored for comparative purposes. Radio-thin-layer chromatography (TLC) was used to measure the binding kinetics and stabilities of the complexes formed. The long-lived isotope, ${ }^{207} \mathrm{Bi}\left(\mathrm{t}_{1 / 2}=32\right.$ years), was used for these studies. Density functional theory (DFT) calculations were also employed to probe the ligand interactions with $\mathrm{Bi}^{3+}$ and the generator parent ion $\mathrm{Ac}^{3+}$.

Results: In contrast to DOTA and CHX-A"-DTPA, these nitrogen-rich macrocycles selectively chelate $\mathrm{Bi}^{3+}$ in the presence of the parent isotope $\mathrm{Ac}^{3+}$. Among the four tested, $\mathrm{L}^{\mathrm{py}}$ was found to exhibit optimal $\mathrm{Bi}^{3+}$-binding kinetics and complex stability. $\mathrm{L}^{\mathrm{py}}$ complexes $\mathrm{Bi}^{3+}$ more rapidly than DOTA, yet the resulting complexes are of similar stability. DFT calculations corroborate the experimentally observed selectivity of these ligands for $\mathrm{Bi}^{3+}$ over $\mathrm{Ac}^{3+}$.

Conclusion: Taken together, these data implicate $\mathrm{L}^{\mathrm{py}}$ as a valuable chelating agent for the delivery of ${ }^{213} \mathrm{Bi}$. Its selectivity for $\mathrm{Bi}^{3+}$ and rapid and stable labeling properties warrants further investigation and biological studies.
\end{abstract}

Keywords: targeted $\alpha$-therapy, bismuth-213, actinium-225, radiolabeling, radio-thin-layer chromatography, macrocycles

*Corresponding Author(s): Justin J. Wilson (jjwilson@lanl.gov) or Eva R. Birnbaum (eva@lanl.gov)

Abbreviated Title: Nitrogen-Rich Ligands for Bismuth Chelation 


\section{Introduction}

High-energy $\alpha$-particles emitted by the decay of radioactive isotopes can be harnessed with an appropriate biological targeting vector to destroy malignant cells [1-3]. This therapeutic strategy, known as $\alpha$-therapy, is the subject of intense current research, with its utility emphasized by the recent FDA-approval of the $\alpha$-emitter ${ }^{223} \mathrm{RaCl}_{2}$ for the treatment of bone metastases arising from castration-resistant prostate cancer [4]. The short range (several cell diameters) and high linear energy transfer $(\approx 100 \mathrm{keV} / \mu \mathrm{m})$ of emitted $\alpha$-particles suggests their use in the treatment of micro-metastatic disease, where irradiation can be limited to the targeted cells. However, the limited availability of $\alpha$-emitting nuclides with appropriate physical properties for therapy hinders their development for clinical application $[5,6]$.

Among the radionuclides proposed for targeted $\alpha$-therapy (TAT), the decay chain of ${ }^{213} \mathrm{Bi}$ $\left(\mathrm{t}_{1 / 2}=45.6 \mathrm{~m}, 97.8 \% \beta^{-}, 2.2 \% \alpha\right)$, which entails an $\alpha$ emission from either of two possible branches thanks to its $\alpha$-emitting daughter, ${ }^{213} \mathrm{Po}\left(\mathrm{t}_{1 / 2}=3.72 \mu \mathrm{s}, 100 \% \alpha\right)$ has shown significant promise. The short half-life of ${ }^{213} \mathrm{Bi}$ is suitable for use with small-molecule and peptide-based targeting agents. Furthermore, its short half-life and small decay chain (Fig. 1) minimize toxic side effects that may arise from long-lived daughter nuclides, which can redistribute to nontarget sites in vivo [7]. ${ }^{213} \mathrm{Bi}$ can also be conveniently obtained from a generator system comprised of its longer-lived parent ${ }^{225} \mathrm{Ac}\left(\mathrm{t}_{1 / 2}=9.9 \mathrm{~d}, 100 \% \alpha\right)$, which is attractive for clinical use [8-11]. Such generator systems are currently commercially available from Oak Ridge National Laboratory in the United States and the Institute for Transuranium Elements in Germany, with future commercial development underway at the Institute for Physics and Power Engineering in Russia [12]. Although the widespread availability of the ${ }^{225}$ Ac parent isotope is limited currently, impeding the further development of ${ }^{213} \mathrm{Bi}$ pharmaceuticals [13], significant 
progress has been made toward the large-scale production of ${ }^{225} \mathrm{Ac}$ [14-17]. The great therapeutic utility of ${ }^{213} \mathrm{Bi}$ is reflected by the several clinical trials that have employed this isotope for cancer treatment [18-23]. The potential of ${ }^{213} \mathrm{Bi}$ and other $\alpha$-emitters for the treatment of infectious diseases is currently under intense investigation as well [24-26].

Fig. 1. Decay chain of ${ }^{213} \mathrm{Bi}$, including ancestral isotopes from the ${ }^{233} \mathrm{U}$ decay series.

Despite the promise of ${ }^{213} \mathrm{Bi}$ TAT, the element bismuth has complicated aqueous chemistry, rendering its complexation for biological delivery challenging. The high affinity of $\mathrm{Bi}^{3+}$ for $\mathrm{OH}^{-}(\log K=12.9)[27]$ indicates the strong tendency of this ion to hydrolyze at even at slightly acidic $\mathrm{pH}$ values. Challenges associated with the aqueous chemistry of $\mathrm{Bi}^{3+}$ have largely hindered the development and rational design of chelating ligands. Ligands currently used for TAT with ${ }^{213} \mathrm{Bi}$ are DOTA (1,4,7,10-tetraazacyclododecane-1,4,7,10-tetraacetic acid) and CHXA"-DTPA $(N-[(R)-2$-amino-3-(p-isothiocyanato-phenyl)propyl]-trans- $(S, S)$-cyclohexane-1,2diamine- $N, N, N^{\prime}, N^{\prime \prime}, N^{\prime \prime}$-pentaacetic acid), shown in Fig. 2. Radiolabeling kinetics for DOTA are generally slow, and both CHX-A"-DTPA and DOTA have high affinity for metal ions other than $\mathrm{Bi}^{3+}$. The development of other bifunctional chelating agents for $\mathrm{Bi}^{3+}$, which exhibit fast radiolabeling kinetics, high stability, and good metal ion selectivity, would be welcome additions to DOTA and CHX-A"-DTPA for ${ }^{213} \mathrm{Bi}$ TAT. A ligand that is highly selective for $\mathrm{Bi}^{3+}$ may minimize the effects of ${ }^{225} \mathrm{Ac}$ breakthrough from the ${ }^{225} \mathrm{Ac} /{ }^{213} \mathrm{Bi}$ generator, which may occur after operator error. 
Recently, we described a series of nitrogen-rich macrocyclic ligands and explored their coordination chemistry with $\mathrm{La}^{3+}[28]$. These ligands (Fig. 2), $\mathrm{L}^{\mathrm{py}}$ (1,4,7,10-tetrakis(pyridin-2ylmethyl)-1,4,7,10-tetraazacyclododecane), $\mathrm{L}^{\text {pyd }}$ (1,4,7,10-tetrakis(3-pyridazylmethyl)-1,4,7,10tetraazacyclododecane), $\mathrm{L}^{\mathrm{pyr}}$ (1,4,7,10-tetrakis(4-pyrimidylmethyl)-1,4,7,10tetraazacyclododecane), and $\mathrm{L}^{\mathrm{pz}}$ (1,4,7,10-tetrakis(2-pyrazinylmethyl)-1,4,7,10tetraazacyclododecane), are structurally homologous, varying only in the nature of the pendant $N$-heterocyclic donors. The pendant donors vary in their relative basicity and chemical hardness values. In our previous work, we demonstrated how these subtle electronic modifications across this series of ligands have significant effects on the solution behavior of their $\mathrm{La}^{3+}$ complexes [28]. Here, we describe the utility of this class of ligands for the selective and stable chelation of radiobismuth. The fast radiolabeling kinetics, high stability, and good selectivity for $\mathrm{Bi}^{3+}$ over the generator parent $\mathrm{Ac}^{3+}$ indicate that these ligands may be useful for ${ }^{213} \mathrm{Bi}$ TAT.

Fig 2. Structures and abbreviated names of ligands investigated in this work.

\section{Materials and methods}

\subsection{General}

Aqueous buffers were prepared using $18 \mathrm{M} \Omega \cdot \mathrm{cm}$ Milli-Q water obtained from a Millipore filtration system. Trace metal-free Optima-grade acids and bases used for adjusting $\mathrm{pH}$ were obtained from Fisher Scientific. Other buffer components were obtained from commercial vendors and were of the highest purity available. The ligands DOTA and CHX-A"-DTPA were 
purchased from Fluka Scientific and Macrocyclics, Inc (Dallas, TX, USA), respectively. The other ligands, $\mathrm{L}^{\mathrm{py}}, \mathrm{L}^{\mathrm{pyd}}, \mathrm{L}^{\mathrm{pyr}}$, and $\mathrm{L}^{\mathrm{pz}}$, were synthesized as previously described $[28,29]$. Alumina-backed silica gel thin-layer chromatography (TLC) plates were obtained from EMD Millipore. A Cyclone Plus Phosphor Imager from Perkin Elmer was used to visualize radioactivity on developed TLC plates. An Ortec (Oak Ridge, TN) p-type Al-windowed high purity $\mathrm{Ge}(\mathrm{HPGe})$ gamma spectrometer with a relative efficiency of approximately $15 \%$ was used to measure activities in the TLC plates $\left(\mathrm{FWHM}_{1333 \mathrm{keV}}=1.9 \mathrm{keV}\right)$. The detector energy and efficiency calibration and background are checked regularly, and analysis of acquired spectra was accomplished with the Ortec GammaVision software package. For stable element analysis, inductively coupled plasma atomic emission spectroscopy (ICP-AES), using a Shimadzu ICPE9000 instrument equipped with a $2 \mathrm{~cm} \times 2 \mathrm{~cm} \mathrm{CCD}$. Calibration solutions from $\mathrm{Pb}$ and $\mathrm{Bi}$ were prepared from certified stocks. All other elements were determined using a qualitative measurement method based on calibrating the response of the instrument to known concentrations of two reference elements, namely $\mathrm{Al}$ and $\mathrm{Ba}$. Analyses were performed in triplicate and based on a $30 \mathrm{~s}$ sample exposure time. Output data were managed and analyzed using the ICPE solutions software version 1.01 (Shimadzu Corp. 2005).

${ }^{225} \mathrm{Ac}$ was obtained from ${ }^{229} \mathrm{Th}$, which was taken from a historic LANL stock supply, immobilized on a column of anion exchange resin as the nitrate salt. The purity of ${ }^{229} \mathrm{Th}$ was verified by ICP-OES, revealing the absence of quasi-stable ${ }^{232} \mathrm{Th}$, and gamma spectroscopy, signifying the absence of gamma-emitting isotopes other than those from the ${ }^{229} \mathrm{Th}$ decay chain. ${ }^{225} \mathrm{Ac}$, a daughter of ${ }^{229} \mathrm{Th}$, was eluted from the column and purified from ${ }^{225} \mathrm{Ra}$, as previously described $[9,30]$, and obtained as the nitrate salt in $0.05 \mathrm{M} \mathrm{HNO}_{3} \cdot{ }^{207} \mathrm{Bi}$, as the nitrate salt in dilute nitric acid, was used from LANL Isotope Program stock supply. The purity of this sample 
was verified by HPGe gamma spectroscopy and by ICP-AES, which revealed the absence of contaminating radioisotopes or substantial quantities of stable elements $(<50 \mu \mathrm{g} / \mathrm{L} \mathrm{Bi}$ and $\mathrm{Pb})$. The presence of small quantities of ${ }^{208} \mathrm{Bi}\left(\mathrm{t}_{1 / 2}=3.7 \times 10^{7}\right.$ years, $\left.100 \% \mathrm{EC}\right)$, co-produced with ${ }^{207} \mathrm{Bi}$ from ${ }^{\text {nat }} \mathrm{Pb}(\mathrm{p}, \mathrm{xn})$ reactions and beneath the detection limits of our spectroscopic equipment configurations, cannot be ruled out.

\section{2. ${ }^{225}$ Ac and ${ }^{207 / 213}$ Bi selectivity studies}

${ }^{225} \mathrm{Ac}(9 \mathrm{kBq}, 0.02 \mathrm{pmol}), 24 \mathrm{~h}$ after elution and purification from the ${ }^{229} \mathrm{Th}$ generator, was mixed with ${ }^{207} \mathrm{Bi}(3 \mathrm{kBq}, 7.3 \mathrm{pmol})$ and ligand $(1 \mathrm{mM}, 500 \mathrm{nmol})$ in $0.1 \mathrm{M} \mathrm{NH}_{4} \mathrm{OAc}$ at $\mathrm{pH}$ 5 and room temperature $\left(22 \pm 2{ }^{\circ} \mathrm{C}\right)$ in a total reaction volume of $500 \mu \mathrm{L}$. At different time points, $5 \mu \mathrm{L}$ aliquots were spotted on silica gel TLC plates. The plates were developed with a mobile phase of $0.4 \mathrm{M} \mathrm{NaCitrate}$ at $\mathrm{pH} 4$ with $10 \%$ methanol. Under these conditions, free metal ions migrated with the solvent front $\left(\mathrm{R}_{\mathrm{f}}=1\right)$ and metal ions bound to the ligand remained at the baseline $\left(R_{f}=0\right)$. These $R_{f}$ values were verified by phosphor imaging of the TLC plates (Fig. 3 ). After development, the TLC plates were cut in half $\left(\mathrm{R}_{\mathrm{f}}=0.5\right)$, and each half was measured by HPGe gamma spectroscopy. Reported uncertainties are derived from the statistical counting errors of the HPGe detector. The $218 \mathrm{keV}$ gamma line of the ${ }^{221} \mathrm{Fr}$ daughter of ${ }^{225} \mathrm{Ac}$ was used to quantify the activity of Ac, whereas the $570 \mathrm{keV}$ gamma line of ${ }^{207} \mathrm{Bi}$ was used for $\mathrm{Bi}$ quantification. The $440 \mathrm{keV}$ gamma line of ${ }^{213} \mathrm{Bi}$ could also potentially be used. However, its short half-life (45.6 min) and continuing generation from the decay of ${ }^{225}$ Ac limited its utility. Therefore, the use of ${ }^{207} \mathrm{Bi}$ as a longer-lived analogue $\left(\mathrm{t}_{1 / 2}=31.6\right.$ years, $\left.100 \% \mathrm{EC}\right)$ enabled quantification of $\mathrm{Bi}^{3+}$ chelation properties of the ligands. 
Fig. 3. Representative silica gel TLC plate, visualized with a phosphor imager. The mobile phase was $0.4 \mathrm{M} \mathrm{NaCitrate} \mathrm{pH} 4.0$ with $10 \%$ methanol.

\section{$2.3{ }^{207}$ Bi radiolabeling kinetics}

In a total reaction volume of $500 \mu \mathrm{L}$ in a plastic Eppendorf tube, $3 \mathrm{kBq}(7.3 \mathrm{pmol})$ of ${ }^{207} \mathrm{Bi}$ was incubated with 10,100 , or $1000 \mu \mathrm{M}$ of the ligands tested. The rate of complexation was monitored by TLC. Aliquots $(5 \mu \mathrm{L})$ were spotted on silica gel TLC plates at different time points. The system used was the same as that described above. The activity was quantified by the $570 \mathrm{keV}$ gamma emission of ${ }^{207} \mathrm{Bi}$. Variations in temperature were achieved by submerging the Eppendorf tubes in hot water baths. The $\mathrm{pH}$ was adjusted to desired values with glacial acetic acid or ammonium hydroxide.

\subsection{EDTA-challenge stability studies}

Bismuth-ligand complexes were formed by incubating $4.8 \mathrm{kBq}(11.7 \mathrm{pmol}){ }^{207} \mathrm{Bi}$ and the ligand $(0.5 \mathrm{mM}, 60 \mathrm{nmol})$ in $120 \mu \mathrm{L}$ of $0.1 \mathrm{M}$ phosphate-buffered saline (PBS) at $\mathrm{pH} 7.4$ and room temperature $\left(22 \pm 2{ }^{\circ} \mathrm{C}\right)$. Radio-TLC of the reaction mixture after $24 \mathrm{~h}$ revealed $>95 \%$ labeling of ${ }^{207} \mathrm{Bi}$. A $100 \mu \mathrm{L}$ portion of the labeled ${ }^{207} \mathrm{Bi}$ solutions was diluted to a total volume of $500 \mu \mathrm{L}$ with EDTA dissolved in $\mathrm{pH} 7.40 .1 \mathrm{M}$ PBS. The final ligand concentration was $100 \mu \mathrm{M}$ and the final EDTA concentration was $50 \mathrm{mM}$. At different time points, $5 \mu \mathrm{L}$ aliquots of the reaction mixture were spotted on a silica gel TLC plate. For these studies a mobile phase of 0.1 M EDTA at pH 7.4 was used. EDTA-complexed metal ions migrated with the solvent front $\left(\mathrm{R}_{\mathrm{f}}=\right.$ 1), whereas the other complexes remained at the baseline $\left(R_{f}=0\right)$. As described above, the loss of ${ }^{207} \mathrm{Bi}$ from the ligands was determined by cutting the TLC plates in half and measuring the activity on each end with a HPGe gamma spectrometer. 


\subsection{Cold metal ion stability studies}

${ }^{207} \mathrm{Bi}$-labeled complexes were prepared by the incubation of ligands $(0.5 \mathrm{mM}, 100 \mathrm{nmol})$ in $0.1 \mathrm{M} 3$-( $N$-morpholino)propanesulfonic acid (MOPS) buffer at pH 7.4 with $3 \mathrm{kBq}(7.3 \mathrm{pmol})$ ${ }^{207} \mathrm{Bi}$ for $24 \mathrm{~h}$ at ambient room temperature $\left(22 \pm 2{ }^{\circ} \mathrm{C}\right)$ in a total volume of $200 \mu \mathrm{L}$. Quantitative (> 95\%) radiolabeling of the ${ }^{207} \mathrm{Bi}$ was verified by radio-TLC. After 24 hours, the solution was split into 4 aliquots and the complexes were challenged with $0.1 \mu \mathrm{mol}$ of cold metal in $100 \mathrm{mM}$ MOPS (i.e., $0.5 \mathrm{mM}$ metal and $0.11 \mathrm{mM}$ ligand), bringing the solution to a total volume of 200 $\mu \mathrm{L}$. At different time points, $5 \mu \mathrm{L}$ aliquots of the reaction mixture were spotted on a silica gel TLC plate. For these studies, a mobile phase of $0.4 \mathrm{M}$ NaCitrate at $\mathrm{pH} 4$ with $10 \%$ methanol was used, as described above. The loss of ${ }^{207} \mathrm{Bi}$ from the ligands was determined by cutting the TLC plates in half and measuring the activity on each side with a HPGe gamma spectrometer.

\subsection{DFT calculations}

Density functional theory (DFT) calculations were carried out using Gaussian09 [31]. The hybrid B3LYP functional was utilized $[32,33]$. Ac, La, and Bi atoms were assigned the quasi-relativistic Stuttgart/Dresden (SDD) effective core potential [34]. The associated segmented basis set [35] was modified for Ac and La by removing g functions and removing the most diffuse functions, those with exponential constants of less than 0.05 . Other atoms were given the Pople-style 6-31G(d) basis set [36, 37]. Geometry optimizations were carried out in the gas-phase. Starting geometries for optimizations were taken and modified as necessary from crystallographic data for $\left[\mathrm{Bi}\left(\mathrm{L}^{\mathrm{py}}\right)\right]^{3+}[38],\left[\mathrm{La}\left(\mathrm{L}^{\mathrm{py}}\right)\left(\mathrm{OH}_{2}\right)\right]^{3+}[28],[\mathrm{Bi}(\mathrm{DOTA})]^{1-}[39]$, $\left[\mathrm{La}(\mathrm{DOTA})\left(\mathrm{OH}_{2}\right)\right]^{1-}[40]$, and $[\mathrm{Bi}(\mathrm{CHX}-\mathrm{DTPA})]^{2-}[41]$, where CHX-DTPA is the analogous ligand to CHX-A"-DTPA without the benzyl isothiocyanate group. The hydrated ion starting geometries were obtained from previous computational studies on a similar system [42]. 
Frequency calculations were employed to obtain thermodynamic parameters and to verify that all structures are local minima on the potential energy surface. Free energy values in water were calculated by single-point calculations of the gas-phase optimized structures in the SMD continuum solvation model [43]. Thermochemical corrections were taken from the gas-phase frequency calculations, adjusted for a pressure of 1354 atm due to the density of liquid water [44], and applied to the SCF energies of the single-point SMD-solution calculations to estimate free energy values in aqueous solution. Ligand strain energies were obtained from single-point energy calculations of the metal complexes in the absence of the metal ion. The SMD solvation model was applied for these calculations as well. Coordinates and energies of optimized structures are given in the Supplementary data.

\section{Results}

\section{1. ${ }^{225}$ Ac and ${ }^{207}$ Bi competition study}

The ability of the nitrogen-rich macrocycles, DOTA, and CHX-A"-DTPA to complex ${ }^{225} \mathrm{Ac}$ and Bi was investigated. ${ }^{225} \mathrm{Ac}$ was eluted from a ${ }^{229} \mathrm{Th}$ generator and purified from ${ }^{225} \mathrm{Ra}$, as previously described $[9,30]$. After reaching secular equilibrium with its daughters, a $9 \mathrm{kBq}$ portion of ${ }^{225} \mathrm{Ac}$ was spiked with $4 \mathrm{kBq}$ of ${ }^{207} \mathrm{Bi} .{ }^{207} \mathrm{Bi}\left(\mathrm{t}_{1 / 2}=32\right.$ a) was used as a longer-lived surrogate for the short-lived therapeutically relevant ${ }^{225} \mathrm{Ac}$ daughter, ${ }^{213} \mathrm{Bi}\left(\mathrm{t}_{1 / 2}=45.6 \mathrm{~min}\right)$. The resulting radioisotope mixture was incubated with $1 \mathrm{mM}$ ligand at $\mathrm{pH} 5$ and room temperature. The labeling was monitored by radio-TLC, using the conditions described above in Section 2.2. The energy of the gamma emissions on the TLC plate could be used to identify specific isotopes. The $218 \mathrm{keV}$ peak of short-lived ${ }^{221} \mathrm{Fr}$, the immediate daughter of ${ }^{225} \mathrm{Ac}$, provided a convenient handle to quantify the activity of actinium. Although ${ }^{213} \mathrm{Bi}$ has a convenient gamma line at 440 $\mathrm{keV}$, its short half-life (45.6 min) and the presence of ${ }^{225} \mathrm{Ac}$, which constantly generates more of 
this isotope through decay, hinders its direct use for these studies. Hence, ${ }^{207} \mathrm{Bi}$ was introduced as a surrogate. The 32 year half-life and $570 \mathrm{keV}$ gamma line of this isotope facilitate its use.

The quantity of ${ }^{225} \mathrm{Ac}$ - and ${ }^{213} \mathrm{Bi}$-labeled ligands at different time points is given in Table 1. As Table 1 shows, the nitrogen-rich macrocycles fail to label ${ }^{225}$ Ac even after $24 \mathrm{~h}$. In contrast, quantitative labeling of ${ }^{207} \mathrm{Bi}$ is observed for all these ligands after $1 \mathrm{~h}$. DOTA and CHX-A"-DTPA fail to show selectivity for Bi over Ac; after $24 \mathrm{~h}$, all ${ }^{225} \mathrm{Ac}$ is bound by DOTA and $30 \%$ of the ${ }^{225} \mathrm{Ac}$ is complexed by CHX- A"-DTPA. These studies reveal that the nitrogenrich macrocycles possess a distinct selectivity for $\mathrm{Bi}^{3+}$ over $\mathrm{Ac}^{3+}$ in contrast to the conventionally used polyamino carboxylate ligands.

Table 1. Results of ${ }^{225}$ Ac and ${ }^{207} \mathrm{Bi}$ Competition Studies ${ }^{a}$

\begin{tabular}{|c|c|c|c|c|c|c|c|}
\hline & Time & $\mathbf{L}^{\mathbf{p y}}$ & $L^{\text {pyd }}$ & $L^{\text {pyr }}$ & $\mathbf{L}^{\mathbf{p z}}$ & DOTA & CHX-A"-DTPA \\
\hline$\%{ }^{225} \mathrm{Ac}$ & $30 \mathrm{~min}$ & 0 & 0 & 0 & 0 & $44 \pm 4$ & 0 \\
\hline \multirow[t]{2}{*}{ Bound } & $60 \mathrm{~min}$ & 0 & 0 & 0 & 0 & $63 \pm 5$ & $9 \pm 2$ \\
\hline & $24 \mathrm{~h}$ & 0 & 0 & 0 & 0 & $94 \pm 6$ & $30 \pm 3$ \\
\hline \multirow[t]{3}{*}{$\%{ }^{207}$ Bi Bound } & $30 \mathrm{~min}$ & $98 \pm 7$ & $97 \pm 6$ & $88 \pm 6$ & $77 \pm 3$ & $82 \pm 6$ & $98 \pm 6$ \\
\hline & $60 \mathrm{~min}$ & $100 \pm 7$ & $100 \pm 7$ & $96 \pm 6$ & $94 \pm 6$ & $86 \pm 6$ & $100 \pm 8$ \\
\hline & $24 \mathrm{~h}$ & $100 \pm 6$ & $100 \pm 7$ & $100 \pm 7$ & $100 \pm 7$ & $93 \pm 6$ & $100 \pm 7$ \\
\hline
\end{tabular}

${ }^{a}$ Conditions are described in Section 2.2. Reported uncertainties are derived from statistical counting errors of the HPGe detector.

\section{2. ${ }^{207}$ Bi radiolabeling kinetics}

${ }^{207} \mathrm{Bi}(3 \mathrm{kBq}, 7.3 \mathrm{pmol})$ was incubated with $100 \mu \mathrm{M}(50 \mathrm{nmol})$ ligand in $1 \mathrm{M} \mathrm{NH}_{4} \mathrm{OAc}$ at pH 5 and ambient temperature $\left(22 \pm{ }^{\circ} \mathrm{C}\right)$ to a total reaction volume of $500 \mu \mathrm{L}$. Kinetics were 
probed using the same TLC system as described above in conjunction with HPGe gamma spectroscopy. Fig. 4 shows the kinetic trace for the radiolabeling reactions. Under these conditions, CHX-A"-DTPA complexes $90 \%$ of the ${ }^{207} \mathrm{Bi}$ after only $5 \mathrm{~min}$. $\mathrm{L}^{\mathrm{py}}$ is the second fastest ligand tested with $>90 \%$ labeling observed after 30 min. Notably, it is faster than DOTA. The radiolabeling kinetics of the remaining three ligands follows the order $\mathrm{L}^{\mathrm{pyd}}>\mathrm{L}^{\mathrm{pyr}}>\mathrm{L}^{\mathrm{pz}}$.

Fig. 4. Radiolabeling kinetics of ${ }^{207} \mathrm{Bi}$. The reaction was carried out in $1 \mathrm{M} \mathrm{NH}_{4} \mathrm{OAc}$ at $\mathrm{pH} 5$ and $22 \pm 2{ }^{\circ} \mathrm{C}$. A total reaction volume of $500 \mu \mathrm{L}$ with $3 \mathrm{kBq}$ of ${ }^{207} \mathrm{Bi}$ and $100 \mu \mathrm{M}$ of ligand was used. Purple stars are CHX-A"-DTPA, orange open circles are DOTA, black filled squares are $\mathrm{L}^{\mathrm{py}}$, blue filled triangles are $\mathrm{L}^{\mathrm{pyd}}$, green open squares are $\mathrm{L}^{\mathrm{pyr}}$, and red filled circles are $\mathrm{L}^{\mathrm{pz}}$. Error bars are derived from statistical counting errors of the HPGe detector by standard error propagation calculations.

To further investigate the labeling properties of the nitrogen-rich macrocycles, the $\mathrm{pH}$, temperature, and ligand concentrations were varied. Upon decreasing the ligand concentration to $10 \mu \mathrm{M}$ (684 molar equiv to $\mathrm{Bi})$ at room temperature and $\mathrm{pH} 5$, the reaction kinetics were substantially slower. After $1 \mathrm{~h}, 50 \pm 5 \%$ of ${ }^{207} \mathrm{Bi}$ was labeled by $\mathrm{L}^{\mathrm{py}}$, whereas $<10 \%$ was complexed by the other three ligands. At 24 h, $92 \pm 6,79 \pm 6,69 \pm 6$, and $35 \pm 4 \%$ of ${ }^{207} \mathrm{Bi}$ was chelated by $\mathrm{L}^{\mathrm{py}}, \mathrm{L}^{\mathrm{pyd}}$, $\mathrm{L}^{\mathrm{pyr}}$, and $\mathrm{L}^{\mathrm{pz}}$, respectively, at this low ligand concentration. As expected, a 10 -fold increase in the ligand concentration to $1000 \mu \mathrm{M}$ gives rise to faster reaction kinetics, as shown in Fig. 5a. $\mathrm{L}^{\mathrm{py}}$ complexes all ${ }^{207} \mathrm{Bi}$ within $5 \mathrm{~min}$, and $>85 \%$ is bound by the slowest ligand, $\mathrm{L}^{\mathrm{pz}}$, within $1 \mathrm{~h}$. Variations in the temperature of the reaction, while maintaining ligand concentration of $100 \mu \mathrm{M}$ and solution $\mathrm{pH}$ 5, also elicited changes in the kinetic profiles. At 37 ${ }^{\circ} \mathrm{C}$, the labeling of $\mathrm{L}^{\mathrm{py}}$ was quantitative after only five minutes (Fig. 5b). Additionally, 
significant enhancements of the kinetics were observed for the other three ligands (Fig 5b). At 65 and $90{ }^{\circ} \mathrm{C}$, labeling for all four ligands is complete within five minutes. Lastly, the effect of $\mathrm{pH}$ was investigated, while fixing the ligand concentration at $100 \mu \mathrm{M}$ and the reaction temperature at $22 \pm 2{ }^{\circ} \mathrm{C}$. At $\mathrm{pH} 3$, kinetics are significantly retarded. After $24 \mathrm{~h}$ at $\mathrm{pH} 3$, only $\mathrm{L}^{\mathrm{py}}$ fully complexes the ${ }^{207} \mathrm{Bi}$. For $\mathrm{L}^{\mathrm{pyd}}, \mathrm{L}^{\mathrm{pyr}}$, and $\mathrm{L}^{\mathrm{pz}}$, only $53 \pm 5,44 \pm 4$, and $43 \pm 3 \%$, respectively, of ${ }^{207} \mathrm{Bi}$ is labeled after $24 \mathrm{~h}$ at $\mathrm{pH} 3$. Conversely, increasing the $\mathrm{pH}$ leads to an enhancement of the reaction kinetics. Fig. 5c shows the kinetic profile for the reaction at $\mathrm{pH} 6.8$. Under these conditions quantitative labeling for all four ligands is achieved by $30 \mathrm{~min}$.

Fig. 5. Radiolabeling kinetics as a function of different ligand concentration, temperature, and $\mathrm{pH}$. (a) Reaction carried out using $1000 \mu \mathrm{M}$ ligand and $3 \mathrm{kBq}{ }^{207} \mathrm{Bi}$. The temperature was fixed at $22 \pm 2{ }^{\circ} \mathrm{C}$ and the $\mathrm{pH}$ at 5 . (b) Reaction carried out at $37 \pm 2{ }^{\circ} \mathrm{C}$ with $3 \mathrm{kBq}{ }^{207} \mathrm{Bi}$. The ligand concentration was $100 \mu \mathrm{M}$ and the $\mathrm{pH}$ was 5 . (c) Reaction carried out at $\mathrm{pH} 6.8$ with $3 \mathrm{kBq}{ }^{207} \mathrm{Bi}$. The ligand concentration was $100 \mu \mathrm{M}$ and the temperature was $22 \pm 2{ }^{\circ} \mathrm{C}$. Error bars are derived from statistical counting errors of the HPGe detector by standard error propagation calculations.

\subsection{EDTA-challenge stability studies}

To assess the stability of the radiobismuth-labeled ligands, the complexes were incubated with a large excess of EDTA. The ${ }^{207} \mathrm{Bi}$ complexes, prepared from $3 \mathrm{kBq}{ }^{207} \mathrm{Bi}$ and $100 \mu \mathrm{M}$ ligand, were challenged with $50 \mathrm{mM}$ EDTA in $\mathrm{pH}$ 7.4 PBS. The loss of ${ }^{207} \mathrm{Bi}$ was monitored by radio-TLC, as described in Section 2.4. The stability of the complexes as a function of time is shown in Fig. 6. $\mathrm{L}^{\mathrm{pyr}}$ and $\mathrm{L}^{\mathrm{pz}}$ form the least stable complexes, with $>50 \%$ of ${ }^{207} \mathrm{Bi}$ lost after 2 days. After 7 days, CHX-A"-DTPA equilibrates with $\approx 10 \%$ loss of ${ }^{207} \mathrm{Bi}$. The complex of $\mathrm{L}^{\text {pyd }}$ is slightly more stable under these conditions, as reflected by an approximate $6 \%$ loss of ${ }^{207} \mathrm{Bi}$. 
Both $\mathrm{L}^{\mathrm{py}}$ and DOTA display excellent stability to the EDTA challenge; $>97 \%$ of the ${ }^{207} \mathrm{Bi}$ complexes remain intact after 7 days.

Fig. 6. Stability of ${ }^{207} \mathrm{Bi}$-labeled complexes $\left(100 \mu \mathrm{M}\right.$ ligand, $\left.3 \mathrm{kBq}{ }^{207} \mathrm{Bi}\right)$ in the presence of 50 $\mathrm{mM}$ EDTA at 0.1 M PBS at pH 7.4. Purple stars are CHX-A"-DTPA, orange open circles are DOTA, black filled squares are $\mathrm{L}^{\mathrm{py}}$, blue filled triangles are $\mathrm{L}^{\mathrm{pyd}}$, green open squares are $\mathrm{L}^{\mathrm{pyr}}$, and red filled circles are $\mathrm{L}^{\mathrm{pz}}$. Error bars are derived from statistical counting errors of the HPGe detector by standard error propagation calculations.

\subsection{Metal-ion competition studies}

The ${ }^{207} \mathrm{Bi}$-labeled ligands $\left(110 \mu \mathrm{M}\right.$ ligand, $\left.0.75 \mathrm{kBq}{ }^{207} \mathrm{Bi}\right)$ were challenged with a large excess $(500 \mu \mathrm{M}$, total reaction volume $200 \mu \mathrm{L})$ of non-radioactive $\mathrm{Cu}^{2+}, \mathrm{Zn}^{2+}, \mathrm{Fe}^{3+}$, and $\mathrm{Bi}^{3+}$ as another determinant of stability. The results are shown in Fig. $7 .{ }^{207} \mathrm{Bi}$ complexes of $\mathrm{L}^{\mathrm{py}}$, DOTA, and CHX-A"-DTPA all remain >95\% intact up to 7 days when challenged with any of the four metal ions. $\mathrm{L}^{\text {pyd }}$ exhibits approximately $10 \%$ decomposition after 7 days in the presence of $\mathrm{Cu}^{2+}$, $\mathrm{Zn}^{2+}$, and $\mathrm{Bi}^{3+}$. Complexes of $\mathrm{L}^{\mathrm{pz}}$ are the least stable with $>70 \%$ loss of ${ }^{207} \mathrm{Bi}$ when challenged with $\mathrm{Cu}^{2+}$ and $\mathrm{Zn}^{2+}$, and $\approx 60 \%$ lost when challenged with cold $\mathrm{Bi}^{3+}$ ions. $\mathrm{L}^{\mathrm{pyr}}$ also exhibits substantial decomposition, albeit less than that for $\mathrm{L}^{\mathrm{pz}}$, when treated with the metal ions, as shown in Fig. 7. $\mathrm{Fe}^{3+}$ ions fail to displace any significant quantities of the ${ }^{207} \mathrm{Bi}$ for all four ligands tested.

Fig. 7. Stability of ${ }^{207} \mathrm{Bi}$-labeled complexes $\left(110 \mu \mathrm{M}\right.$ ligand, $\left.0.75 \mathrm{kBq}{ }^{207} \mathrm{Bi}\right)$ in the presence of $0.5 \mathrm{mM}$ cold (a) $\mathrm{Cu}^{2+}$, (b) $\mathrm{Zn}^{2+}$, (c) $\mathrm{Fe}^{3+}$, and (d) $\mathrm{Bi}^{3+}$ in $0.1 \mathrm{M} \mathrm{pH} 7.4$ MOPS buffer. Purple stars are CHX-A"-DTPA, orange open circles are DOTA, black filled squares are $\mathrm{L}^{\mathrm{py}}$, blue filled 
triangles are $\mathrm{L}^{\mathrm{pyd}}$, green open squares are $\mathrm{L}^{\mathrm{pyr}}$, and red filled circles are $\mathrm{L}^{\mathrm{pz}}$. Error bars are derived from statistical counting errors of the HPGe detector by standard error propagation calculations.

\subsection{DFT calculations}

To investigate the selectivity of the ligands for $\mathrm{Bi}^{3+}$ over $\mathrm{Ac}^{3+}$, DFT calculations were employed. The metal ion substitution reactions, shown in Fig. 8, were modeled by optimizing the geometries and calculating the free energies of all the species. Nine-coordinate hydrated ions with outer-sphere water molecules were optimized to attain energies with some degree of explicit solvation for these ions. The starting geometries for these aquated ions were taken from previously published computational studies on the hydration of lanthanides [42]. For complexes of the ligands, axial water ligands were omitted from the $\mathrm{Bi}^{3+}$ complexes to match the known 8 coordinate structures of this ion $[38,39]$. To balance the chemical reactions, an additional water molecule was added to the outer-sphere of the hydrated $\mathrm{La}^{3+}$ and $\mathrm{Ac}^{3+}$ ions. Additionally, all of the metal complexes were optimized as the twisted square antiprimastic (TSAP) diastereomers, $\Delta(\delta \delta \delta \delta) / \Lambda(\lambda \lambda \lambda \lambda)$, where $\Delta / \Lambda$ indicate the helical twist of the pendant donors and $\delta / \lambda$ signify the chirality of each of the five-membered chelate rings. The TSAP diastereomers are thermodynamically favored for large ions [45].

The hydrated ions of $\mathrm{Bi}^{3+}, \mathrm{La}^{3+}$, and $\mathrm{Ac}^{3+}$ interact with 9 water molecules in the inner coordination sphere. The resulting geometries of the inner-sphere complexes for all three ions are capped twisted square antiprisms. The average inner-sphere $\mathrm{M}-\mathrm{OH}_{2}$ distances for these optimized structures are 2.537, 2.624, and $2.691 \AA$ for $\mathrm{Bi}^{3+}, \mathrm{La}^{3+}$, and $\mathrm{Ac}^{3+}$, respectively. The 
distance between the axial water ligand and the metal ion is approximately $0.1 \AA$ greater than the separation between the other water ligands. Solid-state structures, elucidated by X-ray crystallography, of the $\left[\mathrm{Bi}\left(\mathrm{OH}_{2}\right)_{9}\right]^{3+}$ and $\left[\mathrm{La}\left(\mathrm{OH}_{2}\right)_{9}\right]^{3+}$ cations reveal $D_{3 h^{-}}$-symmetric trigonal tricapped prismatic geometries with average $\mathrm{M}-\mathrm{OH}_{2}$ distances of 2.54 and $2.49 \AA$, respectively [46-48]. Thus, the DFT calculations, which employed gas-phase optimizations, overestimate these distances, but reproduce the general trend in relative distances for $\mathrm{Bi}^{3+}$ and $\mathrm{La}^{3+}$. $\mathrm{Ac}^{3+}$ with the largest ionic radius of the three ions [49] expectedly has, according to DFT calculations, the longest $\mathrm{M}-\mathrm{OH}_{2}$ distances. The optimized structures of the metal-ligand complexes also reflect the increase of ionic radii of the three ions. Average $\mathrm{M}-\mathrm{N}$ distances for the nitrogen-rich macrocyclic compounds, which do not vary significantly depending on the ligand, are 2.64, 2.77, and $2.85 \AA$ for $\mathrm{Bi}^{3+}, \mathrm{La}^{3+}$, and $\mathrm{Ac}^{3+}$, respectively. The substantially shorter $\mathrm{M}-\mathrm{N}$ distances for the $\mathrm{Bi}^{3+}$ complexes may arise, in part, from the lack of axial water ligand in these species.

Free energies with an implicit solvation model, for the $\mathrm{Bi}^{3+} / \mathrm{La}^{3+}$ and $\mathrm{Bi}^{3+} / \mathrm{Ac}^{3+}$ substitution reactions are given in Table 2. These results indicate that complexes of $\mathrm{Bi}^{3+}$ for all six ligands investigated are strongly thermodynamically favored relative to the corresponding complexes of $\mathrm{La}^{3+}$ and $\mathrm{Ac}^{3+} . \mathrm{Ac}^{3+}$ complexes are systematically destabilized relative to those of $\mathrm{La}^{3+}$ as well. Notably, the nitrogen-rich macrocycles strongly prefer $\mathrm{Bi}^{3+}$ to $\mathrm{La}^{3+}$ and $\mathrm{Ac}^{3+}$; the free energy difference for this substitution reaction is much greater than for that with DOTA and CHX-DTPA.

Fig. 8. Reaction schemes used to calculate metal-ion substitution energies with DFT. Results are shown in Table 2. Note that overall complex charges for DOTA and CHX-DTPA are -1 and -2 , respectively. 
Table 2. Free Energies (kJ/mol) Calculated by DFT for the Metal-Ion Exchange Reactions Shown in Fig. 8

\begin{tabular}{lllllll}
\hline & $\mathbf{L}^{\mathbf{p y}}$ & $\mathbf{L}^{\mathbf{p y d}}$ & $\mathbf{L}^{\mathbf{p y r}}$ & $\mathbf{L}^{\mathbf{p} \mathbf{z}}$ & DOTA & CHX-DTPA \\
\hline $\mathrm{La}^{3+}$ & 172.1 & 137.8 & 161.2 & 152.8 & 97.5 & 98.9 \\
$\mathrm{Ac}^{3+}$ & 267.7 & 230.0 & 241.9 & 240.9 & 164.5 & 163.4 \\
\hline
\end{tabular}

To probe directly the relative thermodynamic selectivity of the nitrogen-rich macrocycles, DOTA, and CHX-DTPA for $\mathrm{Bi}^{3+}$, the free energies for the reactions shown in Fig. 9 were computed. These reaction schemes avoid use of the free aquated metal ions, and therefore circumvent the associated errors in calculating the relative energies of such species [50]. Table 3 collects the free energies of the reactions in Fig. 9. The substitution of $\mathrm{La}^{3+}$ or $\mathrm{Ac}^{3+}$ in DOTA for $\mathrm{Bi}^{3+}$ in the nitrogen-rich macrocycles is strongly disfavored. These energies indicate that the nitrogen-rich macrocycles are highly selective for $\mathrm{Bi}^{3+}$ in comparison to DOTA. The polyamino carboxylate CHX-DTPA fails to exhibit thermodynamic selectivity over DOTA. The free energies changes for the reactions involving these two ligands are close to zero.

Fig. 9. Reaction schemes used to calculate the relative selectivity of ligands, compared to DOTA, for $\mathrm{Bi}^{3+}$ Results are shown in Table 3. 
Table 3. Free Energies (kJ/mol) Calculated by DFT for Reactions Shown in Fig. 9

\begin{tabular}{lccccc}
\hline & $\mathbf{L}^{\mathbf{p y}}$ & $\mathbf{L}^{\mathbf{p y d}}$ & $\mathbf{L}^{\mathbf{p y r}}$ & $\mathbf{L}^{\mathbf{p z}}$ & $\mathbf{C H X - D T P A}$ \\
\hline $\mathrm{La}^{3+}$ & 74.6 & 40.3 & 63.7 & 55.3 & 1.4 \\
$\mathrm{Ac}^{3+}$ & 103.3 & 65.5 & 77.4 & 76.5 & -1.1 \\
\hline
\end{tabular}

To investigate the origin of this selectivity, the strain energy of the ligands was calculated. The strain energy is the energy of the ligand at the conformation in the optimized structures of the metal complexes. Table 4 contains the relative strain energies of the ligands computed from single-point energy calculations of ligand geometries in the metal complexes.

For all ligands, complexes of $\mathrm{Ac}^{3+}$ give rise to the smallest strain energies, which are normalized to zero. $\mathrm{Bi}^{3+}$ complexes require the largest strain energies. Strain energies show little dependence on the ligand. The exception is $\mathrm{L}^{\mathrm{pyd}}$, which exhibits substantially larger strain energy in the $\mathrm{Bi}^{3+}$ complex compared to the other ligands.

Table 4. Relative Strain Energies $(\mathrm{kJ} / \mathrm{mol})^{a}$ of Ligands in Metal Complexes

\begin{tabular}{lllllll}
\hline & $\mathbf{L}^{\mathbf{p y}}$ & $\mathbf{L}^{\mathbf{p y d}}$ & $\mathbf{L}^{\mathbf{p y r}}$ & $\mathbf{L}^{\mathbf{p z}}$ & DOTA & CHX-DTPA \\
\hline $\mathrm{Ac}^{3+}$ & 0 & 0 & 0 & 0 & 0 & 0 \\
$\mathrm{La}^{3+}$ & 14.8 & 14.3 & 14.2 & 14.9 & 11.7 & 14.5 \\
$\mathrm{Bi}^{3+}$ & 31.7 & 64.1 & 31.3 & 31.7 & 22.9 & 28.2 \\
\hline
\end{tabular}

${ }^{a}$ Normalized to $\mathrm{Ac}^{3+}$ complexes, which exhibit the lowest ligand strain energies 


\section{Discussion}

The design of bifunctional chelating agents that form strong complexes with ${ }^{213} \mathrm{Bi}$ has been the focus of many synthetic efforts. A number of multi-dentate polyamino carboxylate ligands for $\mathrm{Bi}^{3+}$ chelation have been synthesized and characterized [51-60]. In particular, the polyamino carboxylate ligands known as DEPA and NETA exhibit fast $\mathrm{Bi}^{3+}$-labeling kinetics and high stability, making them among the best known ligands for this unique ion $[55,58,59$, 61]. Other researchers have also begun to explore the use of porphyrins and texaphyrins for the stable chelation of radiobismuth [62-65]. Despite these vast synthetic endeavors, most biological and preclinical studies still employ DOTA $[21,66,67]$ or CHX-A"-DTPA $[68,69]$, which are favorable because of their commercial availability and broad utilization for a variety of established radiopharmaceutical applications.

Non-radioactive $\mathrm{Bi}^{3+}$ complexes of $\mathrm{L}^{\mathrm{py}}$, which possess in vitro anticancer activity [70], have previously been reported and characterized [38]. Although proposed for use in ${ }^{213} \mathrm{Bi}$ TAT, these ligands were not further pursued due to their reportedly low water solubility [38]. In our hands, $\mathrm{L}^{\mathrm{py}}$ exhibits good solubility in $\mathrm{pH} 5 \mathrm{NH}_{4} \mathrm{OAc}$ buffer, an effect that can most likely be attributed to either the increase ionic strength of the buffer solution or the slightly acidic $\mathrm{pH}$. In this study, we were initially interested in exploring the coordination chemistry of $\mathrm{L}^{\mathrm{py}}$ and newly prepared analogues with ${ }^{225}$ Ac. Unexpectedly, we found that all four macrocyclic ligands selectively chelate $\mathrm{Bi}^{3+}$ over $\mathrm{Ac}^{3+}$ (Table 1). This behavior is in contrast to DOTA, currently the chelator of choice for ${ }^{225} \mathrm{Ac}[71,72]$, and CHX-A"-DPTA, which both inevitably bind ${ }^{225}$ Ac. Because breakthrough of ${ }^{225} \mathrm{Ac}$ from ${ }^{225} \mathrm{Ac} /{ }^{213} \mathrm{Bi}$ generator systems is a possible concern [73], especially given the potential for human error, ligands with high selectivity for $\mathrm{Bi}^{3+}$ over $\mathrm{Ac}^{3+}$ 
may be valuable in mitigating the effects of such incidents by minimizing undesired patient exposure to longer-lived ${ }^{225} \mathrm{Ac}$.

Prompted by the unique $\mathrm{Bi}^{3+}$-selective labeling properties of these ligands, we further investigated their potentials for use in ${ }^{213} \mathrm{Bi}$ TAT. Radiolabeling kinetic experiments reveal that $\mathrm{L}^{\mathrm{py}}$ complexes $\mathrm{Bi}^{3+}$ faster than DOTA, but more slowly than CHX-A"-DTPA (Fig. 4). The rapid binding kinetics of CHX-A"-DTPA are expected based on its acyclic structure [74]. Many ${ }^{213} \mathrm{Bi}$ constructs utilize DOTA with great efficacy $[21,66,67]$. Therefore, the observation that $\mathrm{L}^{\mathrm{py}}$ binds to $\mathrm{Bi}^{3+}$ more rapidly than DOTA bodes well for its potential use in ${ }^{213} \mathrm{Bi}$ chelation. Surprisingly, the $\mathrm{Bi}^{3+}$-labeling kinetics of the other three ligands varies substantially depending on the nature of the pendant $N$-heterocycle. The order for binding kinetics follows $\mathrm{L}^{\text {py }}>\mathrm{L}^{\text {pyd }}>$ $\mathrm{L}^{\mathrm{pyr}}>\mathrm{L}^{\mathrm{pz}}$. Notably, this sequence follows the $\mathrm{p} K_{\mathrm{a}}$ values of the pendant $N$-heterocycle. Pyridine is the most basic (conjugate acid $\mathrm{p} K_{\mathrm{a}} 5.23$ ) and pyrazine is the least basic (conjugate acid $\mathrm{p} K_{\mathrm{a}}$ 0.65 ); the corresponding values for pyridazine and pyrimidine are 2.33 and 1.30 , respectively. This correlation suggests that analogous ligands with more basic pendant donors, like imidazole, should be investigated for $\mathrm{Bi}^{3+}$ chelation.

The solution $\mathrm{pH}$, temperature, and ligand concentrations were varied to investigate their role in $\mathrm{Bi}^{3+}$ radiolabeling kinetics (Fig. 5). Using only $10 \mu \mathrm{M}$ ligand (L: ${ }^{207} \mathrm{Bi}$ molar ratio 690) at pH 5 and room temperature gives rise to substantially slower binding kinetics; only $50 \%$ of ${ }^{207} \mathrm{Bi}$ is complexed by $\mathrm{L}^{\mathrm{py}}$ and $<10 \%$ by the three other ligands after $60 \mathrm{~min}$. Conversely, the use of $1000 \mu \mathrm{M}$ ligand $\left(\mathrm{L}:{ }^{207} \mathrm{Bi}\right.$ molar ratio of 69,000$)$ increases complexation kinetics. Increases in temperature also predictably accelerate labeling kinetics. Holding the ligand concentration at 100 $\mu \mathrm{M}$ and the reaction $\mathrm{pH}$ at 5 , increasing the temperature to $37^{\circ} \mathrm{C}$, a temperature that is compatible for antibody labeling, gave substantially improved radiolabeling kinetics. After 5 
min, $>90 \%$ of ${ }^{207} \mathrm{Bi}$ was labeled with $\mathrm{L}^{\mathrm{py}}$. After $1 \mathrm{~h}, \mathrm{~L}^{\mathrm{pyd}}$ and $\mathrm{L}^{\mathrm{pyr}}$ were quantitatively labeled, and $>70 \%$ labeling was achieved with $\mathrm{L}^{\mathrm{pz}}$. At 65 and $90{ }^{\circ} \mathrm{C}$, labeling was $100 \%$ for all ligands after $5 \mathrm{~min}$. The role of $\mathrm{pH}$ was also probed. At $\mathrm{pH} 3$ with $100 \mu \mathrm{M}$ ligand and at room temperature, kinetics were substantially impeded. This rate decrease at low $\mathrm{pH}$ most likely arises due to protonation of the ligand, which decreases the available concentration of the metalbinding deprotonated form. At $\mathrm{pH} 6.8$, only a 5 min time period is required to label $100 \%$ of ${ }^{207} \mathrm{Bi}$ with $\mathrm{L}^{\mathrm{py}}$ and $30 \mathrm{~min}$ for the other three ligands. The decrease in competing $\mathrm{H}^{+}$ions at this higher $\mathrm{pH}$ gives rise to acceleration of the labeling. The three variables, $\mathrm{pH}$, temperature, and concentration, investigated here reveal that there are possible strategies for increasing specific activities of the radiolabeled constructs. For short-lived ${ }^{213} \mathrm{Bi}$, the physical decay of this isotope will also provide another challenge in achieving high specific activities. In the absence of temperature-sensitive antibodies, a clear radiolabeling strategy is to use low ligand concentration, neutral $\mathrm{pH}$, and high temperatures for labeling.

In addition to possessing rapid radiolabeling kinetics, the overall stability of the labeled ligands must be high in order to avoid loss of the radioisotope in vivo. To test the stability of the nitrogen-rich macrocycles, the ${ }^{207} \mathrm{Bi}$-labeled ligands $\left(100 \mu \mathrm{M}\right.$ ligand, $3 \mathrm{kBq}{ }^{207} \mathrm{Bi}$, molar ratio 6900) were challenged with $50 \mathrm{mM}$ EDTA at pH 7.4. The results, shown in Fig. 6, reveal that both $\mathrm{L}^{\mathrm{pz}}$ and $\mathrm{L}^{\mathrm{pyr}}$ exhibit poor stability over several days. In contrast, $\mathrm{L}^{\mathrm{py}}$ and $\mathrm{L}^{\mathrm{pyd}}$ retain ${ }^{207} \mathrm{Bi}$ effectively with less than $3 \%$ loss for $\mathrm{L}^{\mathrm{py}}$ and approximately $6 \%$ loss for $\mathrm{L}^{\mathrm{pyd}}$ after 7 days. These values are an improvement to CHX-A"-DTPA where $10 \%$ loss of ${ }^{207} \mathrm{Bi}$ is observed over the same time period. The ${ }^{207} \mathrm{Bi}-\mathrm{DOT} A$ complex is equally stable to that of $\mathrm{L}^{\mathrm{py}}$. The value of $\mathrm{L}^{\mathrm{py}}$ as a chelating agent for $\mathrm{Bi}^{3+}$ is therefore reflected by the observations that its labeling kinetics are substantially enhanced relative to DOTA, yet it forms equally stable complexes. The therapeutic 
isotope, ${ }^{213} \mathrm{Bi}$, only has a 46-min half-life, and therefore the multi-day stability challenges presented out here are not directly relevant to its use. However, this long-term stability can be used to extrapolate the relative stabilities of the species in vivo, where much more challenging conditions are present.

The stability was further probed by challenging the complexes with an excess of nonradioactive metal ions, which can potentially compete with the radiobismuth for ligand-binding. $\mathrm{Cu}^{2+}$ and $\mathrm{Zn}^{2+}$ were chosen because these ions are present in blood plasma. $\mathrm{Fe}^{3+}$ is also present in vivo, and is one of the major metallic contaminants found in reagents and solutions used for radiolabeling. The use of cold $\mathrm{Bi}^{3+}$ for a stability challenge enables a direct probe of the ligand exchange kinetics without complicating factors caused by different thermodynamic affinities for the different metal ions. The metal ions were present in a five-fold excess relative to the ligands, whereas the molar ratio of cold metal ions to ${ }^{207} \mathrm{Bi}$ is $>10^{5}$. The results shown in Fig. 7 are largely consistent with those from the EDTA-challenge stability study; $\mathrm{L}^{\mathrm{pz}}$ and $\mathrm{L}^{\mathrm{pyr}}$ form the least stable complexes. The stability of $\mathrm{L}^{\mathrm{py}}$ is further verified by these studies as well, where the complex remains $100 \%$ intact against any of the offending metals up to seven days. This stability matches those observed for DOTA and CHX-A"-DTPA. In comparing the efficacy of the competing metal ions, it is noteworthy that $\mathrm{Fe}^{3+}$ fails to eject ${ }^{207} \mathrm{Bi}$ from any ligand. This stability in the presence of $\mathrm{Fe}^{3+}$ is valuable because of the ubiquitous presence of this ion both in biology and as a contaminant in standard reagents. In contrast, $\mathrm{Cu}^{2+}$ and $\mathrm{Zn}^{2+}$ are able to effectively displace ${ }^{207} \mathrm{Bi}$ from $\mathrm{L}^{\mathrm{pyr}}$ and $\mathrm{L}^{\mathrm{pz}}$; this observation may indicate a higher affinity of these ligands for $\mathrm{Cu}^{2+}$ and $\mathrm{Zn}^{2+}$ than $\mathrm{Fe}^{3+}$. The replacement of ${ }^{207} \mathrm{Bi}$ with cold $\mathrm{Bi}^{3+}$ is a good indication of the kinetic inertness of the ligands tested, because this exchange is thermoneutral. The low kinetic stability of $\mathrm{L}^{\mathrm{pyr}}$ and $\mathrm{L}^{\mathrm{pz}}$ is revealed by a loss of radioactivity within the ligands. For $\mathrm{L}^{\mathrm{py}}$, DOTA, 
and CHX-A"-DTPA, however, no exchange with cold $\mathrm{Bi}^{3+}$ is observed over the course of 7 days signifying the kinetic inertness of radiolabeled complex. These studies further validate the stability of $\mathrm{L}^{\mathrm{py}}$, indicating that it performs equally well as DOTA and CHX-A"-DTPA against these challenges.

A novel feature of the ligands investigated here is their strong selectivity and affinity for $\mathrm{Bi}^{3+}$. Using the three-parameter equation of Hancock and Martell $[75,76], \log K$, where $K$ is the thermodynamic stability constant, for $\mathrm{NH}_{3}$ can be predicted for any metal ion if the corresponding values for $\mathrm{F}^{-}$and $\mathrm{OH}^{-}$are known. The predicted $\log K$ for $\mathrm{NH}_{3}$ of the $\mathrm{Bi}^{3+}$ ion is 5.1, suggesting a surprisingly high affinity of this ion for nitrogen donors. The high nitrogen affinity of $\mathrm{Bi}^{3+}$ was further verified by polarographic stability constant measurements and structural studies of this ion with multi-dentate nitrogen-donor ligands [77-80]. In contrast, the predicted $\log \mathrm{K}$ for $\mathrm{NH}_{3}$ of $\mathrm{Ac}^{3+}$, using reported values for $\mathrm{F}^{-}$[81] and $\mathrm{OH}^{-}$[82], is only 0.8 . Therefore, one factor dictating the selectivity of the ligands investigated here is the nitrogen-rich donor set that they provide, which is strongly preferred by the $\mathrm{Bi}^{3+}$ ion. An additional factor that can contribute to the observed selectivity is the difference in ionic radii of $\mathrm{Bi}^{3+}$ and $\mathrm{Ac}^{3+} . \mathrm{Ac}^{3+}$ is the largest +3 ion known; its 6-coordinate ionic radius is $1.12 \AA$ [49]. For $\mathrm{Bi}^{3+}$, this value is 1.03 $\AA$ [49], although a revised radius of $0.99 \AA$ has been suggested [48]. The ligand framework of $\mathrm{L}^{\mathrm{py}}$ and analogues may not be able to satisfactorily accommodate the large $\mathrm{Ac}^{3+}$ ion.

DFT calculations were carried out to investigate and confirm experimental findings regarding the selectivity of these ligands for $\mathrm{Bi}^{3+}$ over $\mathrm{Ac}^{3+}$. Complexes of $\mathrm{La}^{3+}$ were also investigated because they possess a similar six-coordinate ionic radius to $\mathrm{Bi}^{3+}(1.03 \AA)$ and have a similarly low affinity for nitrogen-donor ligands as $\mathrm{Ac}^{3+}\left(\log K \mathrm{NH}_{3}=0.2\right.$, estimated from the same three-parameter equation). These $\mathrm{La}^{3+}$ complexes can therefore potentially be utilized to 
disentangle size effects from donor-atom preferences. Optimized structures of the hydrated ions metal-ligand complexes revealed that those of $\mathrm{Bi}^{3+}$ ion contained the shortest metal-ligand interactions of the series. For the nonaaqua ions, the average $\mathrm{Bi}-\mathrm{OH}_{2}$ inner-sphere distance is 2.537 $\AA$, compared to 2.624 and 2.691 $\AA$ for $\mathrm{La}^{3+}$ and $\mathrm{Ac}^{3+}$, respectively. For the nitrogen-rich macrocycles, average $\mathrm{M}-\mathrm{N}$ distances follow the same order; these values are 2.64, 2.77, and 2.85 $\AA$ for complexes of $\mathrm{Bi}^{3+}, \mathrm{La}^{3+}$, and $\mathrm{Ac}^{3+}$, respectively. The increased $\mathrm{M}-\mathrm{L}$ distances for $\mathrm{Ac}^{3+}$ complexes relative to those of $\mathrm{La}^{3+}$ are expected based on its larger ionic radius. The large increase in $\mathrm{M}-\mathrm{L}$ distances, however, in moving from $\mathrm{Bi}^{3+}$ to $\mathrm{La}^{3+}$ is somewhat surprising. Notably, this deviation is observed experimentally by X-ray crystallography where the average $\mathrm{M}-\mathrm{OH}_{2}$ distance for the nonaaqua ions of $\mathrm{La}^{3+}$ is $0.053 \AA$ greater than that of $\mathrm{Bi}^{3+}[46,47]$, and the average $\mathrm{M}-\mathrm{N}$ distance for the $\mathrm{L}^{\mathrm{py}}$ complex of $\mathrm{La}^{3+}$ is $0.116 \AA$ greater than that of $\mathrm{Bi}^{3+}$. The proposed revised six-coordinate ionic radius of $\mathrm{Bi}^{3+}$ of $0.99 \AA$ [48], which is only slightly smaller than the originally suggested value and the ionic radius of $\mathrm{La}^{3+}$, may partially account for the observed contraction. Additionally, the stereoactive $6 \mathrm{~s}^{2}$ lone-pair of $\mathrm{Bi}^{3+}$, which occupies a coordination site, most likely plays an important role as well.

The computed energies of metal ion substitution are given in Table 2. Substitution of $\mathrm{Bi}^{3+}$ for $\mathrm{La}^{3+}$ is strongly favored thermodynamically. The analogous substitution for $\mathrm{Ac}^{3+}$ is even more greatly favored by up to another $100 \mathrm{~kJ} / \mathrm{mol}$. The thermodynamic penalty for replacing $\mathrm{La}^{3+}$ with $\mathrm{Bi}^{3+}$ in DOTA is expected based on the known stability constants of these ions with DOTA. The reported stability constants $(\log K)$ for $[\mathrm{La}(\mathrm{DOTA})]^{1-}$ at $25^{\circ} \mathrm{C}$ range from 21.7 to 24.25 [83-85], whereas the stability constant for $[\mathrm{Bi}(\mathrm{DOTA})]^{1-}$ is 30.3 [39]. This difference in $\log K$ values (8.6) maximally corresponds to a free energy difference of $49 \mathrm{~kJ} / \mathrm{mol}$, a value smaller than that computed with DFT. For CHX-A"-DTPA the $\log K$ for $\mathrm{Bi}^{3+}$ is 34.9 [86]; values 
for $\mathrm{La}^{3+}$ are not reported. Importantly, the nitrogen-rich macrocycles favor $\mathrm{Bi}^{3+}$ coordination relative to $\mathrm{Ac}^{3+}$ by up to $100 \mathrm{~kJ} / \mathrm{mol}$ more than DOTA and CHX-A"-DTPA. This result can manifest maximally in a difference of stability constants of 17 logarithmic units.

Although these values qualitatively show the expected trends the absolute values should be interpreted with caution due to the large deviation between computation and experimental results for DOTA binding affinity. This deviation from experimental results most likely arises from the difficulty in accurately computing the energies of aquated ions [50], which may exist in different protonation states and ion pairs in a $\mathrm{pH}$ - and electrolyte-dependent manner. Hence the selectivity of the nitrogen-rich macrocycles for $\mathrm{Bi}^{3+}$ was computed in comparison to DOTA with the reaction schemes shown in Fig. 9, which do not require energy terms for the aquated ions. The values in Table 3 clearly support the strong selectivity of the nitrogen-rich macrocycles for $\mathrm{Bi}^{3+}$ in comparison to DOTA. These values indicate that neither $\mathrm{Ac}^{3+}$ nor $\mathrm{La}^{3+}$ can effectively compete with $\mathrm{Bi}^{3+}$ for these ligands. In contrast, CHX-DTPA shows no strong metal-binding preference in comparison to DOTA, highlighting the novel selective properties of the nitrogenrich macrocycles. The computed results that coordination to $\mathrm{La}^{3+}$ is less disfavored than to $\mathrm{Ac}^{3+}$ suggests that size of the ion also plays a role. The nitrogen affinity of these two ions is nearly identical, and therefore the larger size of $\mathrm{Ac}^{3+}$ is presumably the major factor in the almost 100 $\mathrm{kJ} / \mathrm{mol}$ free energy difference between coordination of the two ions. This observation highlights the continuing challenge in the development of chelating agents for $\mathrm{Ac}^{3+}[72,87]$, as conventional macrocyclic scaffolds, including DOTA, cannot optimally interact with this large ion. Somewhat paradoxically, ligand strain energies follow the opposite trend in overall metalcomplex stability. Strain energies (Table 4) are smallest for $\mathrm{Ac}^{3+}$ and largest for $\mathrm{Bi}^{3+}$. Presumably the large $\mathrm{Ac}^{3+}$ ion maintains the ligand in an open relaxed state due to Pauli 
repulsion, a steric effect of the large ion. The major consequence of this small ligand strain, however, is the decreased opportunity for orbital overlap, an effect which most likely contributes to the high stability of the $\mathrm{Bi}^{3+}$ complexes.

\section{Conclusions}

The nitrogen-rich macrocylic ligands investigated in this work have a strong selectivity for $\mathrm{Bi}^{3+}$ over $\mathrm{Ac}^{3+}$. This selectivity is important to minimize detrimental effects of ${ }^{225} \mathrm{Ac} /{ }^{213} \mathrm{Bi}$ generator breakthrough that can lead to inadvertent patient dosing with small quantities of longlived ${ }^{225} \mathrm{Ac}$. DFT calculations indicate that coordination of these ligand to either $\mathrm{La}^{3+}$ or $\mathrm{Ac}^{3+}$ is strongly disfavored thermodynamically relative to $\mathrm{Bi}^{3+}$. This thermodynamic preference most likely arises from the high affinity of $\mathrm{Bi}^{3+}$ for nitrogen donors. Hence, the use of nitrogen-rich ligands represents a strategy for designing stable and selective $\mathrm{Bi}^{3+}$ chelating agents. Furthermore, significant differences between the radiolabeling kinetics and stability of the four ligands investigated reveal that subtle electronic differences can manifest in the utility of these ligands for $\mathrm{Bi}^{3+}$ chelation. Therefore, appropriate modification of these electronic parameters can potentially lead to improved ligands for $\mathrm{Bi}^{3+}$. The best candidate for $\mathrm{Bi}^{3+}$ chelation, $\mathrm{L}^{\mathrm{py}}$, exhibits faster kinetics and equal stability to EDTA and cold metal ion competition reactions as DOTA. The synthesis of a bifunctional analog of $\mathrm{L}^{\mathrm{py}}$ and further evaluation of its utility for ${ }^{213} \mathrm{Bi}$ TAT are in progress. Additional efforts are also aimed at using similar rational design principles for the development of an appropriate chelator for ${ }^{225} \mathrm{Ac}$, work which may possibly stimulate further interest in the use of this isotope for therapeutic applications. Controlling the $\alpha$-emitting daughters of ${ }^{225} \mathrm{Ac}$ in vivo, however, presents a formidable challenge that requires creative approaches beyond conventional ligand design strategies.

\section{Acknowledgements}


JJW and MF acknowledge funding support via the LANL/LDRD program through a Seaborg Institute Postdoctoral and Graduate Student Summer Research Fellowship, respectively. JWE thanks the US DOE for a postdoctoral fellowship through the LANL/LDRD program. The research described in this paper was funded by the United States Department of Energy, Office of Science via funding from the Isotope Development and Production for Research and Applications subprogram in the Office of Nuclear Physics, and through the Heavy Element Chemistry Program of BES (RL Martin and ER Batista). The content of this manuscript has been reviewed and approved as LA-UR-14-28015.

\section{Appendix A. Supplementary data}

Supplementary data to this article can be found online at doi:XXXXXXXX.

\section{References}

[1] Couturier O, Supiot S, Degraef-Mougin M, Faivre-Chauvet A, Carlier T, Chatal J-F, et al. Cancer radioimmunotherapy with alpha-emitting nuclides. Eur J Nucl Med Mol Imaging 2005; 32: 601-14.

[2] Brechbiel MW. Targeted $\alpha$-therapy: past, present, future? Dalton Trans 2007; 4918-28.

[3] Kim Y-S, Brechbiel MW. An overview of targeted alpha therapy. Tumor Biol 2012; 33: 573-90.

[4] Pandit-Taskar N, Larson SM, Carrasquillo JA. Bone-seeking radiopharmaceuticals for treatment of osseous metastases, part 1: $\alpha$ Therapy with ${ }^{223}$ Ra-dichloride. J Nucl Med 2014; 55: 268-74.

[5] Morgenstern A, Abbas K, Bruchertseifer F, Apostolidis C. Production of alpha emitters for targeted alpha therapy. Curr Radiopharm 2008; 1: 135-43.

[6] Alpha emitting radionuclides and radiopharmaceuticals for therapy; Technical Meeting Report for the International Atomic Energy Agency: Vienna, Austria, June 2013.

[7] Singh Jaggi J, Kappel BJ, McDevitt MR, Sgouros G, Flombaum CD, Cabassa C, et al. Efforts to control the errant products of a targeted in vivo generator. Cancer Res 2005; 65: 4888-95.

[8] McDevitt MR, Finn RD, Sgouros G, Ma D, Scheinberg DA. An ${ }^{225} \mathrm{Ac} /{ }^{213}$ Bi generator system for therapeutic clinical applications: Construction and operation. Appl Radiat Isot 1999; 50: 895-904.

[9] Apostolidis C, Molinet R, Rasmussen G, Morgenstern A. Production of Ac-225 from Th229 for targeted $\alpha$ therapy. Anal Chem 2005; 77: 6288-91.

[10] Guseva LI, Dogadkin NN. A generator system for production of medical alpharadionuclides Ac-225 and Bi-213. J Radioanal Nucl Chem 2010; 285: 667-73. 
[11] Morgenstern A, Bruchertseifer F, Apostolidis C. Bismuth-213 and actinium-225 Generator performance and evolving therapeutic applications of two generator-derived alpha-emitting radioisotopes. Curr Radiopharm 2012; 5: 221-27.

[12] Zhuikov BL. Production of medical radionuclides in Russia: Status and future-a review. Appl Radiat Isot 2014; 84: 48-56.

[13] Proceedings of the Workshop on the Nation's Need for Isotopes: Present and Future; Rockville, MD, August, 2008.

[14] Weidner JW, Mashnik SG, John KD, Hemez F, Ballard B, Bach H, et al. Proton-induced cross sections relevant to production of ${ }^{225} \mathrm{Ac}$ and ${ }^{223} \mathrm{Ra}$ in natural thorium targets below $200 \mathrm{MeV}$. Appl Radiat Isot 2012; 70: 2602-07.

[15] Weidner JW, Mashnik SG, John KD, Ballard B, Birnbaum ER, Bitteker LJ, et al. ${ }^{225}$ Ac and ${ }^{223} \mathrm{Ra}$ production via $800 \mathrm{MeV}$ proton irradiation of natural thorium targets. Appl Radiat Isot 2012; 70: 2590-95.

[16] Engle JW, Mashnik SG, Weidner JW, Wolfsberg LE, Fassbender ME, Jackman K, et al. Cross sections from proton irradiation of thorium at $800 \mathrm{MeV}$. Phys Rev C 2013; 88: 014604.

[17] Engle JW, Weidner JW, Ballard BD, Fassbender ME, Hudston LA, Jackman KR, et al. Ac, La, and Ce radioimpurities in ${ }^{225}$ Ac produced in $40-200 \mathrm{MeV}$ proton irradiations of thorium. Radiochim Acta 2014; 102: 569.

[18] Jurcic JG, Larson SM, Sgouros G, McDevitt MR, Finn RD, Divgi CR, et al. Targeted $\alpha$ particle immunotherapy for myeloid leukemia. Blood 2002; 100: 1233-39.

[19] Kneifel S, Cordier D, Good S, Ionescu MCS, Ghaffari A, Hofer S, et al. Local targeting of malignant gliomas by the diffusible peptidic vector 1,4,7,10-tetraazacyclododecane-1glutaric acid-4,7,10-triacetic acid-substance P. Clin Cancer Res 2006; 12: 3843-50.

[20] Raja C, Graham P, Rizvi S, Song E, Goldsmith H, Thompson J, et al. Interim analysis of toxicity and response in phase 1 trial of systemic targeted alpha therapy for metastatic melanoma. Cancer Biol Ther 2007; 6: 846-52.

[21] Cordier D, Forrer F, Bruchertseifer F, Morgenstern A, Apostolidis C, Good S, et al. Targeted alpha-radionuclide therapy of functionally critically located gliomas with ${ }^{213} \mathrm{Bi}$ DOTA-[Thi $\left.{ }^{8,} \operatorname{Met}\left(\mathrm{O}_{2}\right)^{11}\right]$-substance P: A pilot trial. Eur J Nucl Med Mol Imaging 2010; 37: 1335-44.

[22] Rosenblat TL, McDevitt MR, Mulford DA, Pandit-Taskar N, Divgi CR, Panageas KS, et al. Sequential cytarabine and $\alpha$-particle immunotherapy with bismuth-213-lintuzumab (HuM195) for acute myeloid leukemia. Clin Cancer Res 2010; 16: 5303-11.

[23] Jurcic JG. Target alpha-particle immunotherapy with bismuth-213 and actinium-225 for acute myeloid leukemia. J Postgrad Med Edu Res 2013; 47: 14-17.

[24] Dadachova E, Casadevall A. Treatment of infection with radiolabeled antibodies. Q J Nucl Med Mol Imaging 2006; 50: 193-204.

[25] Dadachova E. Radioimmunotherapy of infection with ${ }^{213}$ Bi-labeled antibodies. Curr Radiopharm 2008; 1: 234-39.

[26] Dadachova E, Casadevall A. Radioimmunotherapy of infectious diseases. Semin Nucl Med 2009; 39: 146-53.

[27] Martell AE, Critical stability constants. New York: New York, Plenum Press, 1974. 
[28] Wilson JJ, Birnbaum ER, Batista ER, Martin RL, John KD. Synthesis and characterization of nitrogen-rich macrocyclic ligands and an investigation of their coordination chemistry with lanthanum(III). Submitted 2014.

[29] Natrajan LS, Khoabane NM, Dadds BL, Muryn CA, Pritchard RG, Heath SL, et al. Probing the structure, conformation, and stereochemical exchange in a family of lanthanide complexes derived from tetrapyridyl-appended cyclen. Inorg Chem 2010; 49: 7700-09.

[30] Zielinska B, Apostolidis C, Bruchertseifer F, Morgenstern A. An improved method for the production of Ac-225/Bi-213 from Th-229 for targeted alpha therapy. Solvent Extr Ion Exch 2007; 25: 339-49.

[31] Frisch MJ, Trucks GW, Schlegel HB, Scuseria GE, Robb MA, Cheeseman JR, et al. Gaussian 09. Revision B.01. Wallingford, CT: Gaussian, Inc.; 2010.

[32] Lee C, Yang W, Parr RG. Development of the Colle-Salvetti correlation-energy formula into a functional of the electron density. Phys Rev B 1988; 37: 785-89.

[33] Becke AD. Density-functional thermochemistry. III. The role of exact exchange. J Chem Phys 1993; 98: 5648-52.

[34] Cao X, Dolg M. Valence basis sets for relativistic energy-consistent small-core lanthanide pseudopotentials. J Chem Phys 2001; 115: 7348-55.

[35] Cao X, Dolg M. Segmented contraction scheme for small-core lanthanide pseudopotential basis sets. J Mol Struct: THEOCHEM 2002; 581: 139-47.

[36] Hehre WJ, Ditchfield R, Pople JA. Self-consistent molecular orbital methods. XII. Further extensions of Gaussian-type basis sets for use in molecular orbital studies of organic molecules. J Chem Phys 1972; 56: 2257-61.

[37] Hariharan PC, Pople JA. The influence of polarization functions on molecular orbital hydrogenation energies. Theoret Chim Acta 1973; 28: 213-22.

[38] Morfin J-F, Tripier R, Baccon ML, Handel H. Bismuth(III) complexes with tetrapyridylmethyl-cyclen. Inorg Chim Acta 2009; 362: 1781-86.

[39] Csajbók É, Baranyai Z, Bányai I, Brücher E, Király R, Müller-Fahrnow A, et al. Equilibrium, ${ }^{1} \mathrm{H}$ and ${ }^{13} \mathrm{C}$ NMR spectroscopy, and X-ray diffraction studies on the complexes Bi(DOTA) ${ }^{-}$and Bi(DO3A-Bu). Inorg Chem 2003; 42: 2342-49.

[40] Aime S, Barge A, Benetollo F, Bombieri G, Botta M, Uggeri F. A novel compound in the lanthanide(III) DOTA series. X-ray crystal and molecular structure of the complex $\mathrm{Na}\left[\mathrm{La}\left(\right.\right.$ DOTA)La(HDOTA)] $10 \mathrm{H}_{2} \mathrm{O}$. Inorg Chem 1997; 36: 4287-89.

[41] Brechbiel MW, Gansow OA, Pippin CG, Rogers RD, Planalp RP. Preparation of the novel chelating agent $N$-(2-aminoethyl)-trans-1,2-diaminocyclohexane- $N, N^{\prime}, N^{\prime \prime}$ pentaacetic acid ( $\left.\mathrm{H}_{5} \mathrm{CyDTPA}\right)$, a preorganized analogue of diethylenetriaminepentaacetic acid $\left(\mathrm{H}_{5} \mathrm{DTPA}\right)$, and the structures of $\mathrm{Bi}^{\mathrm{III}}(\mathrm{CyDTPA})^{2-}$ and $\mathrm{Bi}^{\mathrm{III}}\left(\mathrm{H}_{2} \mathrm{DTPA}\right)$ complexes. Inorg Chem 1996; 35: 6343-48.

[42] Kuta J, Clark AE. Trends in aqueous hydration across the $4 \mathrm{f}$ period assessed by reliable computational methods. Inorg Chem 2010; 49: 7808-17.

[43] Marenich AV, Cramer CJ, Truhlar DG. Universal solvation model based on solute electron density and on a continuum model of the solvent defined by the bulk dielectric constant and atomic surface tensions. J Phys Chem B 2009; 113: 6378-96.

[44] Martin RL, Hay PJ, Pratt LR. Hydrolysis of ferric ion in water and conformational equilibrium. J Phys Chem A 1998; 102: 3565-73. 
[45] Aime S, Botta M, Fasano M, Marques MPM, Geraldes CFGC, Pubanz D, et al. Conformational and coordination equilibria on DOTA complexes of lanthanide metal ions in aqueous solution studied by ${ }^{1} \mathrm{H}-\mathrm{NMR}$ spectroscopy. Inorg Chem 1997; 36: 205968.

[46] Chatterjee A, Maslen EN, Watson KJ. The effect of the lanthanoid contraction on the nonaaqualanthanoid(III) tris(trifluoromethanesulfonates). Acta Cryst Sect B 1988; 44: 381-86.

[47] Frank W, Reiss GJ, Schneider J. The nonaaquabismuth(III) cation. Angew Chem, Int Ed 1995; 34: 2416-17.

[48] Näslund J, Persson I, Sandström M. Solvation of the bismuth(III) ion by water, dimethyl sulfoxide, $N, N$ '-dimethylpropyleneurea, and $N, N$-dimethylthioformamide. An EXAFS, large-angle X-ray scattering, and crystallographic structural study. Inorg Chem 2000; 39: 4012-21.

[49] Shannon RD. Revised effective ionic radii and systematic studies of interatomic distances in halides and chalcogenides. Acta Cryst Sect A 1976; 32: 751-67.

[50] Keith JM, Batista ER. Theoretical examination of the thermodynamic factors in the selective extraction of $\mathrm{Am}^{3+}$ from $\mathrm{Eu}^{3+}$ by dithiophosphinic acids. Inorg Chem 2011; 51: 13-15.

[51] Brechbiel MW, Pippin CG, McMurry TJ, Milenic D, Roselli M, Colcher D, et al. An effective chelating agent for labelling of monoclonal antibody with ${ }^{212} \mathrm{Bi}$ for $\alpha$-particle mediated radioimmunotherapy. J Chem Soc, Chem Commun 1991; 1169-70.

[52] Brechbiel MW, Gansow OA. Synthesis of C-functionalized transcyclohexyldiethylenetriaminepenta-acetic acids for labelling of monoclonal antibodies with the bismuth-212 $\alpha$-particle emitter. J Chem Soc, Perkin Trans 1 1992; 1173-78.

[53] Garmestani K, Yao Z, Zhang M, Wong K, Park CW, Pastan I, et al. Synthesis and evaluation of a macrocyclic bifunctional chelating agent for use with bismuth radionuclides. Nucl Med Biol 2001; 28: 409-18.

[54] Chong H-S, Milenic DE, Garmestani K, Brady ED, Arora H, Pfiester C, et al. In vitro and in vivo evaluation of novel ligands for radioimmunotherapy. Nucl Med Biol 2006; 33: 459-67.

[55] Chong H-S, Lim S, Baidoo KE, Milenic DE, Ma X, Jia F, et al. Synthesis and biological evaluation of a novel decadentate ligand DEPA. Bioorg Med Chem Lett 2008; 18: 579295.

[56] Chong H-S, Song HA, Ma X, E. Milenic D, D. Brady E, Lim S, et al. Novel bimodal bifunctional ligands for radioimmunotherapy and targeted MRI. Bioconjugate Chem 2008; 19: 1439-47.

[57] Dadwal M, Kang CS, Song HA, Sun X, Dai A, Baidoo KE, et al. Synthesis and evaluation of a bifunctional chelate for development of $\mathrm{Bi}(\mathrm{III})$-labeled radioimmunoconjugates. Bioorg Med Chem Lett 2011; 21: 7513-15.

[58] Song HA, Kang CS, Baidoo KE, Milenic DE, Chen Y, Dai A, et al. Efficient bifunctional decadentate ligand $3 \mathrm{p}-C$-DEPA for targeted $\alpha$-radioimmunotherapy applications. Bioconjugate Chem 2011; 22: 1128-35.

[59] Kang CS, Song HA, Milenic DE, Baidoo KE, Brechbiel MW, Chong H-S. Preclinical evaluation of NETA-based bifunctional ligand for radioimmunotherapy applications 
using ${ }^{212} \mathrm{Bi}$ and ${ }^{213} \mathrm{Bi}$ : Radiolabeling, serum stability, and biodistribution and tumor uptake studies. Nucl Med Biol 2013; 40: 600-05.

[60] Lima LMP, Beyler M, Oukhatar F, Le Saec P, Faivre-Chauvet A, Platas-Iglesias C, et al. $\mathrm{H}_{2} \mathrm{Me}-\mathrm{do} 2 \mathrm{pa}$ : an attractive chelator with fast, stable and inert ${ }^{\text {nat }} \mathrm{Bi}^{3+}$ and ${ }^{213} \mathrm{Bi}^{3+}$ complexation for potential $\alpha$-radioimmunotherapy applications. Chem Commun 2014; 50: 12371-74.

[61] Chong H-S, Song HA, Birch N, Le T, Lim S, Ma X. Efficient synthesis and evaluation of bimodal ligand NETA. Bioorg Med Chem Lett 2008; 18: 3436-39.

[62] Halime Z, Lachkar M, Furet E, Halet J-F, Boitrel B. Linear and pre-organized carboxylic acid picket porphyrins as bismuth chelators. Inorg Chem 2006; 45: 10661-69.

[63] Halime Z, Lachkar M, Boitrel B. Coordination of bismuth and lead in porphyrins: Towards an in-situ generator for alpha-radiotherapy? Biochimie 2009; 91: 1318-20.

[64] Preihs C, Arambula JF, Lynch VM, Siddik ZH, Sessler JL. Bismuth- and lead-texaphyrin complexes: Towards potential $\alpha$-core emitters for radiotherapy. Chem Commun 2010; 46 : 7900-02.

[65] Gac SL, Najjari B, Motreff N, Saec PR-L, Faivre-Chauvet A, Dimanche-Boitrel M-T, et al. Unprecedented incorporation of $\alpha$-emitter radioisotope ${ }^{213} \mathrm{Bi}$ into porphyrin chelates with reference to a daughter isotope mediated assistance mechanism. Chem Commun 2011; 47: 8554-56.

[66] Norenberg JP, Krenning BJ, Konings IRHM, Kusewitt DF, Nayak TK, Anderson TL, et al. ${ }^{213} \mathrm{Bi}$-[DOTA ${ }^{0}, \mathrm{Tyr}^{3}$ ] octreotide peptide receptor radionuclide therapy of pancreatic tumors in a preclinical animal model. Clin Cancer Res 2006; 12: 897-903.

[67] Wild D, Frischknecht M, Zhang H, Morgenstern A, Bruchertseifer F, Boisclair J, et al. Alpha- versus beta-particle radiopeptide therapy in a human prostate cancer model $\left({ }^{213} \mathrm{Bi}\right.$ DOTA-PESIN and ${ }^{213}$ Bi-AMBA versus ${ }^{177}$ Lu-DOTA-PESIN). Cancer Res 2011; 71: 1009-18.

[68] McDevitt MR, Finn RD, Ma D, Larson SM, Scheinberg DA. Preparation of $\alpha$-emitting ${ }^{213}$ Bi-labeled antibody constructs for clinical use. J Nucl Med 1999; 40: 1722-27.

[69] Nikula TK, McDevitt MR, Finn RD, Wu C, Kozak RW, Garmestani K, et al. Alphaemitting bismuth cyclohexylbenzyl DTPA constructs of recombinant humanized antiCD33 antibodies: Pharmacokinetics, bioactivity, toxicity and chemistry. J Nucl Med 1999; 40: 166-76.

[70] Wang X, Zhang X, Lin J, Chen J, Xu Q, Guo Z. DNA-binding property and antitumor activity of bismuth(III) complex with 1,4,7,10-tetrakis(2-pyridylmethyl)-1,4,7,10tetraazacyclododecane. Dalton Trans 2003; 2379-80.

[71] McDevitt MR, Ma D, Lai LT, Simon J, Borchardt P, Frank RK, et al. Tumor therapy with targeted atomic nanogenerators. Science 2001; 294: 1537-40.

[72] McDevitt MR, Ma D, Simon J, Frank RK, Scheinberg DA. Design and synthesis of ${ }^{225}$ Ac radioimmunopharmaceuticals. Appl Radiat Isot 2002; 57: 841-47.

[73] Ma D, McDevitt MR, Finn RD, Scheinberg DA. Breakthrough of ${ }^{225}$ Ac and its radionuclide daughters from an ${ }^{225} \mathrm{Ac} /{ }^{213} \mathrm{Bi}$ generator: Development of new methods, quantitative characterization, and implications for clinical use. Appl Radiat Isot 2001; 55: 667-78.

[74] Price EW, Orvig C. Matching chelators to radiometals for radiopharmaceuticals. Chem Soc Rev 2014; 43: 260-90. 
[75] Hancock RD, Martell AE. Ligand design for selective complexation of metal ions in aqueous solution. Chem Rev 1989; 89: 1875-914.

[76] Martell AE, Hancock RD, Metal complexes in aqueous solutions. New York, NY: Plenum Press, 1996.

[77] Hancock RD, Cukrowski I, Baloyi J, Mashishi J. The affinity of bismuth(III) for nitrogen-donor ligands. J Chem Soc, Dalton Trans 1993; 2895-99.

[78] Hancock RD, Cukrowski I, Antunes I, Cukrowska E, Mashishi J, Brown K. Complexation of $\mathrm{Bi}^{\mathrm{III}}$ by nitrogen donor ligands. A polarographic study. Polyhedron 1995; 14: 1699-707.

[79] Luckay R, Reibenspies JH, Hancock RD. Synthesis and structure of a complex of bismuth(III) with a nitrogen donor macrocycle. J Chem Soc, Chem Commun 1995; 236566.

[80] Luckay R, Cukrowski I, Mashishi J, H. Reibenspies J, H. Bond A, D. Rogers R, et al. Synthesis, stability and structure of the complex of bismuth(III) with the nitrogen-donor macrocycle 1,4,7,10-tetraazacyclododecane. The role of the lone pair on bismuth(III) and lead(II) in determining co-ordination geometry. J Chem Soc, Dalton Trans 1997; 901-08.

[81] Aziz A, Lyle SJ. Complexes of lanthanum and actinium with fluoride, oxalate and sulphate in aqueous solutions. J Inorg Nucl Chem 1970; 32: 1925-32.

[82] Zielińska B, Bilewicz A. The hydrolysis of actinium. J Radioanal Nucl Chem 2004; 261: 195-98.

[83] Cacheris WP, Nickle SK, Sherry AD. Thermodynamic study of lanthanide complexes of 1,4,7-triazacyclononane- $N, N^{\prime}, N^{\prime \prime}$-triacetic acid and 1,4,7,10-tetraazacyclododecane$N, N^{\prime}, N^{\prime \prime}, N^{\prime \prime \prime}$-tetraacetic acid. Inorg Chem 1987; 26: 958-60.

[84] Clarke ET, Martell AE. Stabilities of trivalent metal ion complexes of the tetraacetate derivatives of 12-, 13- and 14-membered tetraazamacrocycles. Inorg Chim Acta 1991; 190: 37-46.

[85] Ling Wu S, DeW. Horrocks W. Direct determination of stability constants of lanthanide ion chelates by laser-excited europium(III) luminescence spectroscopy: application to cyclic and acyclic aminocarboxylate complexes. J Chem Soc, Dalton Trans 1997; 1497 502.

[86] Montavon G, Le Du A, Champion J, Rabung T, Morgenstern A. DTPA complexation of bismuth in human blood serum. Dalton Trans 2012; 41: 8615-23.

[87] Davis IA, Glowienka KA, Boll RA, Deal KA, Brechbiel MW, Stabin M, et al. Comparison of ${ }^{225}$ actinium chelates: Tissue distribution and radiotoxicity. Nucl Med Biol 1999; 26: 581-89. 


\section{Supplementary Data for}

\section{Evaluation of Nitrogen-Rich Macrocyclic Ligands for the Chelation of Therapeutic Bismuth Radioisotopes}

Justin J. Wilson,* Maryline Ferrier, Valery Radchenko, Joel R. Maassen, Jonathan W. Engle, Enrique R. Batista, Richard L. Martin, Francois M. Nortier, Michael E. Fassbender Kevin D. John, Eva R. Birnbaum*

Los Alamos National Laboratory, P.O. Box 1663, Los Alamos, NM, 87545, USA

E-mail:jjwilson@lanl.gov or eva@lanl.gov

Table S1. DFT-optimized Cartesian coordinates and energies for $\left[\mathrm{Bi}\left(\mathrm{OH}_{2}\right)_{9}\right]\left(\mathrm{OH}_{2}\right)_{11}{ }^{3+}$

$\begin{array}{rrrr}\mathrm{O} & 1.237100 & -2.154500 & 0.023500 \\ \mathrm{H} & 1.326700 & -2.665300 & -0.809200 \\ \mathrm{H} & 1.960900 & -2.401400 & 0.647100 \\ \mathrm{O} & -1.194400 & -1.761000 & -1.425000 \\ \mathrm{H} & -1.782200 & -2.442300 & -1.012300 \\ \mathrm{H} & -0.536500 & -2.244900 & -1.979800 \\ \mathrm{O} & 1.188600 & -0.154700 & -1.913500 \\ \mathrm{H} & 2.132500 & -0.427100 & -1.793300 \\ \mathrm{H} & 1.258300 & 0.663700 & -2.449000 \\ \mathrm{O} & -2.612200 & 0.346800 & -0.411600 \\ \mathrm{H} & -3.120600 & 1.042800 & 0.070200 \\ \mathrm{H} & -3.244900 & -0.225300 & -0.896900 \\ \mathrm{O} & -0.407300 & 2.060100 & -0.982200 \\ \mathrm{H} & 0.350700 & 2.696800 & -0.965800 \\ \mathrm{H} & -1.222300 & 2.576100 & -1.161800 \\ \mathrm{O} & 0.838900 & -0.938400 & 2.559100 \\ \mathrm{H} & 0.854600 & -0.174600 & 3.188200 \\ \mathrm{H} & 0.085000 & -1.507600 & 2.807800 \\ \mathrm{O} & 1.815400 & 1.304300 & 0.953800 \\ \mathrm{H} & 2.689800 & 0.835500 & 1.008800 \\ \mathrm{H} & 1.981900 & 2.108000 & 0.393200 \\ \mathrm{O} & -1.621500 & -1.617200 & 1.635000 \\ \mathrm{H} & -2.162200 & -0.950900 & 2.098500 \\ \mathrm{H} & -2.239200 & -2.271700 & 1.215300 \\ \mathrm{O} & -1.325600 & 1.111500 & 2.012100 \\ \mathrm{H} & -0.712700 & 1.473500 & 2.698300 \\ \mathrm{H} & -2.003300 & 1.796600 & 1.795600 \\ \mathrm{O} & 3.931000 & -0.267500 & -1.779200 \\ \mathrm{H} & 4.227700 & -0.200700 & -0.836400 \\ \mathrm{H} & 4.571700 & -0.839300 & -2.234000\end{array}$




$\begin{array}{rrrr}\mathrm{O} & -4.688200 & -1.414500 & -1.368100 \\ \mathrm{H} & -4.775800 & -1.619600 & -2.316100 \\ \mathrm{H} & -5.594000 & -1.209900 & -1.073900 \\ \mathrm{H} & -3.851100 & -2.735100 & -0.443000 \\ \mathrm{O} & -3.066400 & -3.176700 & -0.037900 \\ \mathrm{H} & -3.277900 & -4.119800 & 0.070000 \\ \mathrm{O} & 1.969800 & 3.336700 & -0.834200 \\ \mathrm{H} & 2.402000 & 2.998500 & -1.668000 \\ \mathrm{H} & 2.250300 & 4.257300 & -0.700400 \\ \mathrm{O} & -2.574400 & 3.956100 & -1.210000 \\ \mathrm{H} & -3.179000 & 3.955600 & -1.973300 \\ \mathrm{H} & -2.283700 & 4.881700 & -1.126800 \\ \mathrm{H} & -3.262800 & 3.233700 & 0.300100 \\ \mathrm{O} & -3.421600 & 2.532200 & 0.975500 \\ \mathrm{H} & -4.211900 & 2.783800 & 1.482700 \\ \mathrm{O} & 2.778500 & 1.945100 & -2.940500 \\ \mathrm{H} & 3.046900 & 2.308600 & -3.801300 \\ \mathrm{H} & 3.469700 & 1.297600 & -2.666800 \\ \mathrm{O} & 4.219900 & -0.053300 & 0.926700 \\ \mathrm{H} & 4.031400 & -0.924100 & 1.367600 \\ \mathrm{H} & 5.017100 & 0.311700 & 1.348400 \\ \mathrm{O} & 0.845300 & 1.575300 & 3.527200 \\ \mathrm{H} & 1.425600 & 1.815300 & 2.771200 \\ \mathrm{H} & 1.120700 & 2.076200 & 4.313400 \\ \mathrm{O} & 3.129700 & -2.277700 & 1.987800 \\ \mathrm{H} & 2.411000 & -1.895900 & 2.546000 \\ \mathrm{H} & 3.527300 & -3.022400 & 2.471200 \\ \mathrm{O} & 0.865700 & -3.243100 & -2.536800 \\ \mathrm{H} & 1.280900 & -2.845400 & -3.320900 \\ \mathrm{H} & 0.769400 & -4.189200 & -2.745400 \\ \mathrm{Bi} & -0.240900 & -0.157500 & 0.121500\end{array}$

Zero-point correction $=$

Thermal correction to Energy=

Thermal correction to Enthalpy=

Thermal correction to Gibbs Free Energy=

Sum of electronic and zero-point Energies=

Sum of electronic and thermal Energies $=$

Sum of electronic and thermal Enthalpies=

Sum of electronic and thermal Free Energies=
0.514514 (Hartree/Particle)

0.562458

0.563402

0.436787

$-1532.704093$

$-1532.656149$

$-1532.655205$

$-1532.781821$

$\mathrm{E}(\mathrm{SCF})$ in SMD Solvation Model $=-1533.69815425$

Table S2. DFT-optimized Cartesian coordinates and energies for $\left[\mathrm{La}\left(\mathrm{OH}_{2}\right)_{9}\right]\left(\mathrm{OH}_{2}\right)_{12}{ }^{3+}$ 


$\begin{array}{lrrr}\mathrm{La} & -0.171500 & -0.071700 & -0.063300 \\ \mathrm{O} & 1.142500 & -2.249300 & -0.392600 \\ \mathrm{H} & 1.290600 & -2.599600 & -1.298100 \\ \mathrm{H} & 1.582700 & -2.831600 & 0.269100 \\ \mathrm{O} & -1.014500 & -1.214600 & -2.140900 \\ \mathrm{H} & -1.799100 & -1.817600 & -2.101400 \\ \mathrm{H} & -0.338200 & -1.665800 & -2.701200 \\ \mathrm{O} & 1.842100 & 0.046700 & -1.824400 \\ \mathrm{H} & 2.662800 & -0.423600 & -1.530400 \\ \mathrm{H} & 2.187600 & 0.916300 & -2.117000 \\ \mathrm{O} & -2.348500 & 1.038700 & -0.829400 \\ \mathrm{H} & -2.714800 & 1.780100 & -0.292100 \\ \mathrm{H} & -3.120500 & 0.542100 & -1.188600 \\ \mathrm{O} & 0.342400 & 2.355700 & -0.665800 \\ \mathrm{H} & 1.177100 & 2.784100 & -0.349900 \\ \mathrm{H} & -0.254800 & 3.072900 & -0.974400 \\ \mathrm{O} & 0.147500 & -1.531300 & 2.255200 \\ \mathrm{H} & 0.170800 & -0.929800 & 3.042900 \\ \mathrm{H} & -0.746900 & -1.928700 & 2.202300 \\ \mathrm{O} & 1.942200 & 0.703600 & 1.487300 \\ \mathrm{H} & 2.695000 & 0.062000 & 1.583000 \\ \mathrm{H} & 2.351400 & 1.557000 & 1.181600 \\ \mathrm{O} & -2.134900 & -1.708300 & 0.776900 \\ \mathrm{H} & -2.961700 & -1.334500 & 1.156100 \\ \mathrm{H} & -2.452900 & -2.337000 & 0.081900 \\ \mathrm{O} & -1.284200 & 1.155600 & 1.889400 \\ \mathrm{H} & -0.821400 & 1.206800 & 2.757700 \\ \mathrm{H} & -1.750600 & 2.006700 & 1.716700 \\ \mathrm{O} & 4.392700 & -0.665700 & -1.071800 \\ \mathrm{H} & 4.427300 & -0.890800 & -0.108500 \\ \mathrm{H} & 5.010600 & -1.265900 & -1.521800 \\ \mathrm{O} & -4.663700 & -0.486100 & -1.315400 \\ \mathrm{H} & -5.413800 & -0.213300 & -1.871200 \\ \mathrm{H} & -5.000300 & -0.586400 & -0.394700 \\ \mathrm{H} & -3.905000 & -2.071100 & -1.635100 \\ \mathrm{O} & -3.177000 & -2.731900 & -1.525200 \\ \mathrm{H} & -3.467500 & -3.572300 & -1.917500 \\ \mathrm{O} & 2.801200 & 2.981300 & 0.287800 \\ \mathrm{H} & 3.380700 & 2.736200 & -0.487400 \\ \mathrm{H} & -1.363600 & 4.581600 & -1.148000 \\ \mathrm{H} & -1.65000 & 4.648600 & -1.986700 \\ \mathrm{H} & 3.464700 & -1.012800 \\ \mathrm{H} & 3.884500 & 0.224100 \\ \mathrm{H} & & & \\ \mathrm{H} & -208800 & 0.798800\end{array}$




$\begin{array}{rrrr}\mathrm{H} & -3.547700 & 3.630700 & 1.192400 \\ \mathrm{O} & 3.953500 & 1.930600 & -1.862000 \\ \mathrm{H} & 4.509700 & 2.404400 & -2.503200 \\ \mathrm{H} & 4.435400 & 1.109600 & -1.605600 \\ \mathrm{O} & 3.993900 & -1.134300 & 1.595800 \\ \mathrm{H} & 3.538200 & -2.001100 & 1.764500 \\ \mathrm{H} & 4.715800 & -1.063800 & 2.244000 \\ \mathrm{O} & -4.874800 & -1.061900 & 1.392500 \\ \mathrm{H} & -5.198100 & -0.424000 & 2.052400 \\ \mathrm{H} & -5.349000 & -1.887200 & 1.599900 \\ \mathrm{O} & 0.489300 & 0.622200 & 3.844200 \\ \mathrm{H} & 1.255500 & 0.867700 & 3.279700 \\ \mathrm{H} & 0.699900 & 0.830900 & 4.769800 \\ \mathrm{O} & 2.289300 & -3.218700 & 1.872600 \\ \mathrm{H} & 1.511300 & -2.812200 & 2.320200 \\ \mathrm{H} & 2.424900 & -4.106300 & 2.246400 \\ \mathrm{O} & 1.229900 & -2.370100 & -3.164300 \\ \mathrm{H} & 1.686600 & -1.523200 & -3.322000 \\ \mathrm{H} & 1.383800 & -2.936400 & -3.939800\end{array}$

Zero-point correction $=$

Thermal correction to Energy=

Thermal correction to Enthalpy=
0.539820 (Hartree/Particle)

0.590165

0.591110

0.460008

$-2039.616754$

$-2039.566408$

$-2039.565464$

$-2039.696566$

$\mathrm{E}(\mathrm{SCF})$ in SMD Solvation Model= -2040.66400091

Table S3. DFT-optimized Cartesian coordinates and energies for $\left[\mathrm{Ac}\left(\mathrm{OH}_{2}\right)_{9}\right]\left(\mathrm{OH}_{2}\right)_{12}{ }^{3+}$
Ac $\quad-0.106900 \quad-0.022500-0.071700$
O $\quad 1.148500 \quad-2.359200 \quad-0.212000$
$\mathrm{H} \quad 1.319600 \quad-2.790300 \quad-1.077900$
H $\quad 1.632100 \quad-2.838600 \quad 0.499900$
O $\quad-0.871600-1.376400-2.182100$
$\mathrm{H} \quad-1.666900 \quad-1.961900 \quad-2.131400$
$\mathrm{H} \quad-0.180400 \quad-1.892400 \quad-2.655200$
O $\quad 1.945300 \quad-0.037700 \quad-1.801400$
$\mathrm{H} \quad 2.763100 \quad-0.500800 \quad-1.497400$
H $\quad 2.300600 \quad 0.795600 \quad-2.174800$
$\begin{array}{llll}\mathrm{O} & -2.391300 & 1.014700 & -0.944500\end{array}$
$\mathrm{H} \quad-2.764600 \quad 1.794300 \quad-0.469900$ 


\begin{tabular}{|c|c|c|c|}
\hline $\mathrm{H}$ & -3.154300 & 0.494800 & -1.289100 \\
\hline & 0.388300 & 2.463900 & -0.803900 \\
\hline & 1.236200 & 2.886000 & -0.513400 \\
\hline & -0.199000 & 3.180400 & -1.132500 \\
\hline & 0.111200 & -1.341300 & 2.421500 \\
\hline & 0.027800 & -0.717300 & 3.183200 \\
\hline & -0.747900 & -1.802000 & 2.323400 \\
\hline & 1.985800 & 0.817700 & 1.372400 \\
\hline $\mathrm{H}$ & 2.744900 & 0.225300 & 1.59 \\
\hline 1 & 2.386300 & 1.674100 & 1.077700 \\
\hline U & -2.119300 & -1.732200 & 0.830700 \\
\hline H & -2.981100 & -1.380600 & 1.146900 \\
\hline $\mathrm{H}$ & -2.375400 & -2.386900 & 0.136100 \\
\hline $\mathrm{O}$ & -1.326300 & 1.371000 & 1.844900 \\
\hline H & -0.986900 & 1.434700 & 2.76 \\
\hline $\mathrm{H}$ & -1.820600 & 2.1914 & 1.61 \\
\hline O & 4.503200 & -0.697900 & -0.95 \\
\hline $\mathrm{H}$ & 4.513700 & -0.841300 & 0.01 \\
\hline $\mathrm{H}$ & 5.162500 & -1.304000 & -1.336000 \\
\hline $\mathrm{O}$ & -4.633800 & -0.619200 & -1.43 \\
\hline $\mathrm{H}$ & -5.374200 & -0.401100 & -2.025300 \\
\hline $\mathrm{H}$ & -4.998300 & -0.707300 & -0.5 \\
\hline $\mathrm{H}$ & -3.795300 & -2.182800 & -1.6 \\
\hline $\mathrm{O}$ & -3.070400 & -2.838800 & -1.50 \\
\hline $\mathrm{H}$ & -3.362800 & -3.694200 & -1.8 \\
\hline $\mathrm{O}$ & 2.865200 & 3.083700 & 0.11 \\
\hline $\mathrm{H}$ & 3.448400 & 2.778100 & -0.63 \\
\hline $\mathrm{H}$ & 3.250800 & 3.896400 & 0.476800 \\
\hline $\mathrm{O}$ & -1.367500 & 4.613500 & -1.405300 \\
\hline $\mathrm{H}$ & -1.795700 & 4.624200 & -2.279800 \\
\hline $\mathrm{H}$ & -1.019900 & 5.514900 & -1.283200 \\
\hline $\mathrm{H}$ & -2.393200 & 3.936500 & -0.057000 \\
\hline $\mathrm{O}$ & -2.839800 & 3.292200 & 0.542100 \\
\hline $\mathrm{H}$ & -3.643600 & 3.728000 & 0.871000 \\
\hline $\mathrm{O}$ & 4.051100 & 1.852600 & -1.944700 \\
\hline $\mathrm{H}$ & 4.620400 & 2.271900 & -2.611600 \\
\hline $\mathrm{H}$ & 4.524500 & 1.052800 & -1.617600 \\
\hline $\mathrm{O}$ & 4.077500 & -0.962700 & 1.750200 \\
\hline $\mathrm{H}$ & 3.613200 & -1.805700 & 1.986000 \\
\hline $\mathrm{H}$ & 4.787600 & -0.837200 & 2.402700 \\
\hline $\mathrm{O}$ & -4.905800 & -1.117700 & 1.294300 \\
\hline $\mathrm{H}$ & -5.258100 & -0.445200 & 1.902800 \\
\hline $\mathrm{H}$ & -5.384200 & -1.933600 & 1.527900 \\
\hline $\mathrm{O}$ & -0.125600 & 0.738000 & 4.278900 \\
\hline & 0.725100 & 1.171200 & 4.465600 \\
\hline
\end{tabular}




$\begin{array}{rrrr}\mathrm{H} & -0.579800 & 0.678300 & 5.138100 \\ \mathrm{O} & 2.318600 & -3.009800 & 2.166000 \\ \mathrm{H} & 1.536100 & -2.560000 & 2.560000 \\ \mathrm{H} & 2.446600 & -3.852100 & 2.634900 \\ \mathrm{O} & 1.249400 & -3.031400 & -2.948600 \\ \mathrm{H} & 1.892100 & -2.566800 & -3.511200 \\ \mathrm{H} & 1.123800 & -3.902900 & -3.363200\end{array}$

Zero-point correction $=$

Thermal correction to Energy=

Thermal correction to Enthalpy=

Thermal correction to Gibbs Free Energy=

Sum of electronic and zero-point Energies=

Sum of electronic and thermal Energies=

Sum of electronic and thermal Enthalpies=

Sum of electronic and thermal Free Energies=
0.537141 (Hartree/Particle)

0.589252

0.590196

0.453429

$-1979.705819$

$-1979.653708$

$-1979.652764$

$-1979.789531$

$\mathrm{E}(\mathrm{SCF})$ in SMD Solvation Model= -1980.78691714

Table S4. DFT-optimized Cartesian coordinates and energies for $\left[\mathrm{Bi}\left(\mathrm{L}^{\mathrm{py}}\right)\right]^{3+}$

$\begin{array}{lrrr}\mathrm{C} & 1.250100 & 1.859200 & 2.807600 \\ \mathrm{H} & 1.998700 & 2.534700 & 3.245000 \\ \mathrm{H} & 0.940900 & 1.187600 & 3.611800 \\ \mathrm{C} & 0.064100 & 2.691800 & 2.327400 \\ \mathrm{H} & -0.320700 & 3.276400 & 3.174300 \\ \mathrm{H} & 0.387500 & 3.413500 & 1.574500 \\ \mathrm{C} & -1.859300 & 1.250400 & 2.807500 \\ \mathrm{H} & -2.534800 & 1.999000 & 3.244800 \\ \mathrm{H} & -1.187600 & 0.941300 & 3.611800 \\ \mathrm{C} & -2.691800 & 0.064300 & 2.327500 \\ \mathrm{H} & -3.276300 & -0.320500 & 3.174600 \\ \mathrm{H} & -3.413700 & 0.387500 & 1.574700 \\ \mathrm{C} & -1.250300 & -1.859000 & 2.807800 \\ \mathrm{H} & -1.998900 & -2.534300 & 3.245200 \\ \mathrm{H} & -0.941100 & -1.187200 & 3.611900 \\ \mathrm{C} & -0.064300 & -2.691700 & 2.327800 \\ \mathrm{H} & 0.320600 & -3.276000 & 3.174900 \\ \mathrm{H} & -0.387600 & -3.413700 & 1.575200 \\ \mathrm{C} & 1.859000 & -1.250200 & 2.807700 \\ \mathrm{H} & 1.187400 & -0.941100 & 3.611900 \\ \mathrm{H} & 2.534500 & -1.998800 & 3.245000 \\ \mathrm{C} & 2.691700 & -0.064200 & 2.327800 \\ \mathrm{H} & 3.276000 & 0.320600 & 3.174900 \\ \mathrm{H} & 3.413600 & -0.387500 & 1.575100\end{array}$




\begin{tabular}{|c|c|c|c|}
\hline $\mathrm{C}$ & 2.737000 & 1.885200 & 0.866900 \\
\hline$\theta$ & 3.602100 & 2.243900 & 1.440900 \\
\hline & 2.161800 & 2.769700 & 0.575200 \\
\hline & 3.211400 & 1.177000 & -0.385700 \\
\hline & 4.467700 & 1.453900 & -0.927100 \\
\hline & 5.138700 & 2.141700 & -0.421700 \\
\hline & 4.847500 & 0.839400 & -2.121700 \\
\hline & 5.819800 & 1.044300 & -2.559600 \\
\hline & 3.960700 & -0.046800 & -2.735300 \\
\hline $\mathrm{H}$ & 4.215500 & -0.550200 & -3.661900 \\
\hline & 2.732800 & -0.285300 & -2.126100 \\
\hline $\mathrm{H}$ & 2.021900 & -0.979300 & -2.563100 \\
\hline & -1.885300 & 2.736800 & 0.866500 \\
\hline$\pi$ & -2.244300 & 3.601900 & 1.440300 \\
\hline 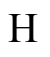 & -2.769600 & 1300 & 4700 \\
\hline C & -1.177000 & 3.211100 & -0.386200 \\
\hline $\mathrm{C}$ & -1.453800 & 4.467400 & -0.927700 \\
\hline $\mathrm{H}$ & -2.141500 & 500 & -0.422200 \\
\hline $\mathrm{C}$ & -0.839400 & 4.847000 & -2.122400 \\
\hline $\mathrm{H}$ & -1.044200 & 5.81 & -2.560300 \\
\hline $\mathrm{C}$ & 0.046700 & 3.960100 & -2.735900 \\
\hline $\mathrm{H}$ & 0.550100 & 4.214700 & -3.662700 \\
\hline $\mathrm{C}$ & 0.285200 & 2.732200 & -2.126600 \\
\hline $\mathrm{H}$ & 0.979100 & 2.021300 & -2.563500 \\
\hline $\mathrm{C}$ & -2.736700 & -1.88 & 0.866700 \\
\hline $\mathrm{H}$ & -3.601600 & -2.244600 & 1.440500 \\
\hline $\mathrm{H}$ & -2.160900 & -2.769300 & 0.574700 \\
\hline $\mathrm{C}$ & -3.211300 & -1.177000 & -0.385800 \\
\hline $\mathrm{C}$ & -4.467700 & -1.453800 & -0.927100 \\
\hline $\mathrm{H}$ & -5.138700 & -2.141500 & -0.421500 \\
\hline $\mathrm{C}$ & -4.847400 & -0.839400 & -2.121800 \\
\hline $\mathrm{H}$ & -5.819700 & -1.044300 & -2.559500 \\
\hline $\mathrm{C}$ & -3.960500 & 0.046600 & -2.735500 \\
\hline $\mathrm{H}$ & -4.215300 & 0.549900 & -3.662200 \\
\hline $\mathrm{C}$ & -2.732500 & 0.285000 & -2.126400 \\
\hline $\mathrm{H}$ & -2.021700 & 0.978900 & -2.563500 \\
\hline $\mathrm{C}$ & 1.885100 & -2.736800 & 0.866700 \\
\hline $\mathrm{H}$ & 2.244100 & -3.601900 & 1.440500 \\
\hline $\mathrm{H}$ & 2.769300 & -2.161200 & 0.574900 \\
\hline $\mathrm{C}$ & 1.176900 & -3.211200 & -0.386000 \\
\hline $\mathrm{C}$ & 1.454100 & -4.467300 & -0.927700 \\
\hline $\mathrm{H}$ & 2.142000 & -5.138300 & -0.422400 \\
\hline $\mathrm{C}$ & 0.839800 & -4.846800 & -2.122500 \\
\hline $\mathrm{H}$ & 1.045000 & -5.818800 & -2.560600 \\
\hline & -0.046500 & -3.960000 & -2.736000 \\
\hline
\end{tabular}




$\begin{array}{lrrr}\mathrm{H} & -0.549800 & -4.214600 & -3.662700 \\ \mathrm{C} & -0.285400 & -2.732300 & -2.126400 \\ \mathrm{H} & -0.979500 & -2.021400 & -2.563300 \\ \mathrm{~N} & 1.871200 & 1.033500 & 1.731800 \\ \mathrm{~N} & -1.033600 & 1.871200 & 1.731500 \\ \mathrm{~N} & -1.871200 & -1.033400 & 1.731700 \\ \mathrm{~N} & 1.033400 & -1.871200 & 1.731700 \\ \mathrm{~N} & 2.356400 & 0.312700 & -0.975900 \\ \mathrm{~N} & -0.312800 & 2.356100 & -0.976300 \\ \mathrm{~N} & -2.356300 & -0.312800 & -0.976100 \\ \mathrm{~N} & 0.312400 & -2.356200 & -0.976000 \\ \mathrm{Bi} & -0.000000 & -0.000000 & 0.196100\end{array}$

Zero-point correction $=$

Thermal correction to Energy=
0.698458 (Hartree/Particle)

0.733338

0.734282

0.633910

$\begin{array}{ll}\text { Sum of electronic and zero-point Energies }= & -1685.392680 \\ \text { Sum of electronic and thermal Energies }= & -1685.357800\end{array}$

Sum of electronic and thermal Enthalpies $=\quad-1685.356856$

Sum of electronic and thermal Free Energies $=\quad-1685.457228$

$\mathrm{E}(\mathrm{SCF})$ in SMD Solvation Model= -1686.53916617

Table S5. DFT-optimized Cartesian coordinates and energies for $\left[\mathrm{Bi}\left(\mathrm{L}^{\mathrm{pyd}}\right)\right]^{3+}$

$\begin{array}{rrrr}\mathrm{C} & 1.923500 & -1.162600 & 2.833700 \\ \mathrm{H} & 2.637500 & -1.868500 & 3.281200 \\ \mathrm{H} & 1.232800 & -0.884300 & 3.632900 \\ \mathrm{C} & 2.696300 & 0.066300 & 2.353500 \\ \mathrm{H} & 3.267200 & 0.470600 & 3.201000 \\ \mathrm{H} & 3.429500 & -0.223400 & 1.597700 \\ \mathrm{C} & 1.162000 & 1.922800 & 2.834300 \\ \mathrm{H} & 1.867600 & 2.636500 & 3.282700 \\ \mathrm{H} & 0.882700 & 1.231800 & 3.633000 \\ \mathrm{C} & -0.066500 & 2.695900 & 2.353700 \\ \mathrm{H} & -0.471300 & 3.266200 & 3.201400 \\ \mathrm{H} & 0.223300 & 3.429900 & 1.598600 \\ \mathrm{C} & -1.922500 & 1.161600 & 2.833800 \\ \mathrm{H} & -2.636200 & 1.867100 & 3.282400 \\ \mathrm{H} & -1.231600 & 0.882400 & 3.632400 \\ \mathrm{C} & -2.695700 & -0.066900 & 2.353300 \\ \mathrm{H} & -3.266400 & -0.471500 & 3.200800 \\ \mathrm{H} & -3.429100 & 0.223000 & 1.597800 \\ \mathrm{C} & -1.161500 & -1.924200 & 2.833300\end{array}$




\begin{tabular}{|c|c|c|c|}
\hline & -0.882400 & -1.234000 & 3.632700 \\
\hline & -1.867200 & -2.638300 & 3.281000 \\
\hline & 0.067000 & -2.696900 & 2.351900 \\
\hline & 0.471900 & -3.268500 & 3.198700 \\
\hline & -0.223300 & -3.429400 & 1.595800 \\
\hline & 2.023500 & -2.666400 & 0.904100 \\
\hline & 2.361100 & -3.556100 & 1.454900 \\
\hline & 2.920500 & -2.086000 & 5900 \\
\hline & 1.374600 & -3.084600 & 0400 \\
\hline & 1.790500 & -4.224700 & 5900 \\
\hline $\mathrm{H}$ & 2.566600 & -4.872800 & 9300 \\
\hline & 1.175500 & -4.484300 & -2.317500 \\
\hline & 1.446100 & -5.344100 & -2.922300 \\
\hline 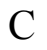 & 0.169400 & -3.599400 & -2.741600 \\
\hline$\theta$ & -0.359400 & -3.746000 & -3.67 \\
\hline$C$ & 2.667300 & 2.022500 & 0.90 \\
\hline $\mathrm{H}$ & 3.556400 & 2.360000 & 1.45 \\
\hline $\mathrm{H}$ & 2.08 & 2.92 & 0.6 \\
\hline 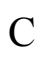 & 3.087900 & 1.373400 & -0.396800 \\
\hline $\mathrm{C}$ & 4.22 & 1.790100 & -1.10 \\
\hline $\mathrm{H}$ & 4.876000 & 2.566300 & -0.703300 \\
\hline C & 4.489600 & 1.176000 & -2.31 \\
\hline $\mathrm{H}$ & 5.349900 & 1.447200 & -2.9 \\
\hline C & 3.605400 & 0.169900 & -2.73 \\
\hline $\mathrm{H}$ & 3.752900 & -0.358100 & -3.6 \\
\hline $\mathrm{C}$ & -2.021800 & 2.667100 & 0.90 \\
\hline $\mathrm{H}$ & -2.358200 & 3.5 & 500 \\
\hline $\mathrm{H}$ & -2.919900 & 2.088300 & 0.667700 \\
\hline $\mathrm{C}$ & -1.372700 & 3.085300 & -0.35 \\
\hline $\mathrm{C}$ & -1.788500 & 4.225600 & -1.103900 \\
\hline $\mathrm{H}$ & -2.563600 & 4.874500 & -0.706600 \\
\hline $\mathrm{C}$ & -1.174800 & 4.484400 & -2.316300 \\
\hline $\mathrm{H}$ & -1.445600 & 5.344300 & -2.921000 \\
\hline $\mathrm{C}$ & -0.169900 & 3.598800 & -2.741200 \\
\hline $\mathrm{H}$ & 0.358100 & 3.744700 & -3.678800 \\
\hline $\mathrm{C}$ & -2.667900 & -2.022700 & 0.906000 \\
\hline $\mathrm{H}$ & -3.556800 & -2.360300 & 1.457900 \\
\hline $\mathrm{H}$ & -2.088400 & -2.919900 & 0.666300 \\
\hline $\mathrm{C}$ & -3.088500 & -1.372600 & -0.397200 \\
\hline $\mathrm{C}$ & -4.231200 & -1.786100 & -1.099900 \\
\hline $\mathrm{H}$ & -4.880200 & -2.560600 & -0.701600 \\
\hline $\mathrm{C}$ & -4.492100 & -1.171100 & -2.311200 \\
\hline $\mathrm{H}$ & -5.353900 & -1.440100 & -2.914000 \\
\hline $\mathrm{C}$ & -3.606200 & -0.167000 & -2.737500 \\
\hline & -3.753700 & 0.361900 & -3.674400 \\
\hline
\end{tabular}




$\begin{array}{lrrr}\mathrm{N} & 1.134500 & -1.833000 & 1.761000 \\ \mathrm{~N} & 1.833100 & 1.134000 & 1.762300 \\ \mathrm{~N} & -1.133800 & 1.832800 & 1.761600 \\ \mathrm{~N} & -1.832800 & -1.134800 & 1.761500 \\ \mathrm{~N} & 0.404300 & -2.296500 & -0.875800 \\ \mathrm{~N} & 2.300700 & 0.402800 & -0.873400 \\ \mathrm{~N} & -0.403600 & 2.296000 & -0.875100 \\ \mathrm{~N} & -2.299200 & -0.404300 & -0.874800 \\ \mathrm{~N} & 0.210000 & 2.537800 & -2.034200 \\ \mathrm{~N} & -2.542900 & 0.211100 & -2.032600 \\ \mathrm{~N} & -0.210500 & -2.538600 & -2.034300 \\ \mathrm{~N} & 2.544100 & -0.211000 & -2.032000 \\ \mathrm{Bi} & -0.000400 & -0.000500 & 0.205500\end{array}$

Zero-point correction=

Thermal correction to Energy=

Thermal correction to Enthalpy=

Thermal correction to Gibbs Free Energy=

Sum of electronic and zero-point Energies $=$

Sum of electronic and thermal Energies=

Sum of electronic and thermal Enthalpies $=$

Sum of electronic and thermal Free Energies=
0.647705 (Hartree/Particle)

0.682307

0.683251

$\mathrm{E}(\mathrm{SCF})$ in SMD Solvation Model $=-1750.56391571$

Table S6. DFT-optimized Cartesian coordinates and energies for $\left[\mathrm{Bi}\left(\mathrm{L}^{\mathrm{pyr}}\right)\right]^{3+}$

$\begin{array}{rrrr}\mathrm{C} & -0.258500 & -2.227300 & 2.809800 \\ \mathrm{H} & -0.611100 & -3.169600 & 3.251300 \\ \mathrm{H} & -0.292000 & -1.485900 & 3.611200 \\ \mathrm{C} & 1.176500 & -2.425300 & 2.327200 \\ \mathrm{H} & 1.786200 & -2.772500 & 3.172600 \\ \mathrm{H} & 1.216800 & -3.214200 & 1.573000 \\ \mathrm{C} & 2.227300 & -0.259200 & 2.809600 \\ \mathrm{H} & 3.169300 & -0.611800 & 3.251500 \\ \mathrm{H} & 1.485400 & -0.292800 & 3.610700 \\ \mathrm{C} & 2.425300 & 1.175900 & 2.327300 \\ \mathrm{H} & 2.772600 & 1.785500 & 3.172800 \\ \mathrm{H} & 3.214000 & 1.216300 & 1.572900 \\ \mathrm{C} & 0.259400 & 2.226700 & 2.810300 \\ \mathrm{H} & 0.612300 & 3.168700 & 3.252100 \\ \mathrm{H} & 0.293300 & 1.484800 & 3.611300 \\ \mathrm{C} & -1.175700 & 2.424800 & 2.328400 \\ \mathrm{H} & -1.785100 & 2.771700 & 3.174200 \\ \mathrm{H} & -1.216400 & 3.213900 & 1.574500\end{array}$




$\begin{array}{lrrr}\mathrm{C} & -2.226200 & 0.258700 & 2.810600 \\ \mathrm{H} & -1.484100 & 0.292100 & 3.611400 \\ \mathrm{H} & -3.168100 & 0.611200 & 3.252800 \\ \mathrm{C} & -2.424400 & -1.176200 & 2.328100 \\ \mathrm{H} & -2.771100 & -1.786000 & 3.173700 \\ \mathrm{H} & -3.213600 & -1.216500 & 1.574300 \\ \mathrm{C} & -1.582000 & -2.947200 & 0.885500 \\ \mathrm{H} & -2.209400 & -3.640500 & 1.461900 \\ \mathrm{H} & -0.674400 & -3.496000 & 0.613500 \\ \mathrm{C} & -2.294300 & -2.549300 & -0.389500 \\ \mathrm{C} & -3.249400 & -3.373400 & -0.978400 \\ \mathrm{H} & -3.554400 & -4.308500 & -0.519200 \\ \mathrm{C} & -3.802300 & -2.951600 & -2.192000 \\ \mathrm{H} & -4.549100 & -3.547900 & -2.711000 \\ \mathrm{C} & 2.947800 & -1.582400 & 0.885300 \\ \mathrm{H} & 3.640800 & -2.210300 & 1.461600 \\ \mathrm{H} & 3.496900 & -0.674800 & 0.614000 \\ \mathrm{C} & 2.549700 & -2.294000 & -0.390100 \\ \mathrm{C} & 3.373800 & -3.248500 & -0.979700 \\ \mathrm{H} & 4.309100 & -3.553600 & -0.521000 \\ \mathrm{C} & 2.951800 & -3.800800 & -2.193600 \\ \mathrm{H} & 3.548200 & -4.547100 & -2.713200 \\ \mathrm{~N} & 1.581700 & 2.947400 & 0.885400 \\ \mathrm{~N} & 1.381500 & -1.935800 & -0.972000 \\ \mathrm{H} & 2.208700 & 3.641100 & 1.461700 \\ \mathrm{H} & 0.673600 & 3.495400 & 0.613600 \\ \mathrm{C} & 2.293900 & 2.549700 & -0.389600 \\ \mathrm{C} & 3.248000 & 3.374400 & -0.979200 \\ \mathrm{H} & 3.552700 & 4.309700 & -0.520500 \\ \mathrm{C} & 3.800300 & 2.952700 & -2.193200 \\ \mathrm{H} & 4.546300 & 3.549600 & -2.712900 \\ \mathrm{C} & -2.947300 & 1.582200 & 0.886500 \\ \mathrm{H} & -3.640100 & 2.209900 & 1.463000 \\ \mathrm{H} & -3.496300 & 0.674600 & 0.615000 \\ \mathrm{C} & -2.549600 & 2.294200 & -0.388800 \\ & -3.374300 & 3.248200 & -0.978500 \\ \mathrm{H} & -4.309500 & 3.553200 & -0.519600 \\ \mathrm{~N} & -3.549900 & 4.545900 & -2.712700 \\ \mathrm{~N} & 1.193100 & -1.783200 & 1.732700 \\ \mathrm{~N} & -1.3813600 & 1.783000 & 1.732700 \\ \mathrm{~N} & -0.971700\end{array}$




$\begin{array}{rrrr}\mathrm{N} & -1.381600 & 1.936400 & -0.971200 \\ \mathrm{C} & 2.538900 & 1.068000 & -2.138400 \\ \mathrm{C} & -1.068300 & 2.538600 & -2.138200 \\ \mathrm{C} & -2.539300 & -1.067600 & -2.138400 \\ \mathrm{C} & 1.067600 & -2.538500 & -2.138600 \\ \mathrm{H} & 2.251700 & 0.128200 & -2.601700 \\ \mathrm{H} & -0.128600 & 2.251100 & -2.601600 \\ \mathrm{H} & 0.127800 & -2.250900 & -2.601700 \\ \mathrm{H} & -2.251600 & -0.128200 & -2.602100 \\ \mathrm{~N} & 3.445000 & 1.797300 & -2.771000 \\ \mathrm{~N} & 1.796300 & -3.445000 & -2.771200 \\ \mathrm{~N} & -3.446500 & -1.796400 & -2.770300 \\ \mathrm{~N} & -1.797700 & 3.444400 & -2.771000 \\ \mathrm{Bi} & 0.000300 & 0.000000 & 0.206000\end{array}$

Zero-point correction $=$

Thermal correction to Energy=

Thermal correction to Enthalpy=
0.650606 (Hartree/Particle)

0.685036

0.685981

Thermal correction to Gibbs Free Energy= 0.586441

Sum of electronic and zero-point Energies $=\quad-1749.540789$

Sum of electronic and thermal Energies $=\quad-1749.506359$

Sum of electronic and thermal Enthalpies $=\quad-1749.505415$

Sum of electronic and thermal Free Energies $=\quad-1749.604954$

$\mathrm{E}(\mathrm{SCF})$ in SMD Solvation Model= $=-1750.69765961$

Table S7. DFT-optimized Cartesian coordinates and energies for $\left[\mathrm{Bi}\left(\mathrm{L}^{\mathrm{pz}}\right)\right]^{3+}$

$\begin{array}{rrrr}\mathrm{C} & 2.217900 & -0.311600 & 2.797900 \\ \mathrm{H} & 3.151100 & -0.690200 & 3.236700 \\ \mathrm{H} & 1.475500 & -0.328100 & 3.598700 \\ \mathrm{C} & 2.448700 & 1.118900 & 2.318900 \\ \mathrm{H} & 2.802200 & 1.721400 & 3.166200 \\ \mathrm{H} & 3.240600 & 1.145500 & 1.568000 \\ \mathrm{C} & 0.305600 & 2.216000 & 2.799300 \\ \mathrm{H} & 0.683200 & 3.148900 & 3.239400 \\ \mathrm{H} & 0.319800 & 1.473200 & 3.599700 \\ \mathrm{C} & -1.123600 & 2.447300 & 2.316500 \\ \mathrm{H} & -1.728300 & 2.801600 & 3.162000 \\ \mathrm{H} & -1.147700 & 3.238800 & 1.565100 \\ \mathrm{C} & -2.221000 & 0.304500 & 2.795700 \\ \mathrm{H} & -3.154600 & 0.682300 & 3.234200 \\ \mathrm{H} & -1.479300 & 0.319100 & 3.597200 \\ \mathrm{C} & -2.451300 & -1.125000 & 2.313500 \\ \mathrm{H} & -2.805600 & -1.729300 & 3.159300\end{array}$




$\begin{array}{lrrr}\mathrm{H} & -3.242700 & -1.150100 & 1.562000 \\ \mathrm{C} & -0.308600 & -2.222600 & 2.794200 \\ \mathrm{H} & -0.323700 & -1.481200 & 3.595900 \\ \mathrm{H} & -0.687000 & -3.156300 & 3.232200 \\ \mathrm{C} & 1.121000 & -2.453400 & 2.312800 \\ \mathrm{H} & 1.724500 & -2.809400 & 3.158400 \\ \mathrm{H} & 1.146000 & -3.243600 & 1.559900 \\ \mathrm{C} & 2.904200 & -1.641100 & 0.861700 \\ \mathrm{H} & 3.591500 & -2.274000 & 1.439300 \\ \mathrm{H} & 3.463300 & -0.741400 & 0.585300 \\ \mathrm{C} & 2.483300 & -2.360400 & -0.399800 \\ \mathrm{C} & 3.282100 & -3.363900 & -0.966800 \\ \mathrm{H} & 4.199000 & -3.690200 & -0.479600 \\ \mathrm{C} & 1.835900 & -3.577200 & -2.714300 \\ \mathrm{H} & 1.575300 & -4.063400 & -3.651100 \\ \mathrm{C} & 1.012200 & -2.594100 & -2.158400 \\ \mathrm{H} & 0.085100 & -2.298400 & -2.639000 \\ \mathrm{C} & 1.639800 & 2.902300 & 0.866400 \\ \mathrm{H} & 2.271400 & 3.589500 & 1.445200 \\ \mathrm{H} & 0.740700 & 3.461500 & 0.588100 \\ \mathrm{C} & 2.361600 & 2.481600 & -0.393700 \\ \mathrm{H} & -3.58500 \\ \mathrm{C} & 3.367700 & 3.279400 & -0.957300 \\ \mathrm{H} & 3.694300 & 4.195200 & -0.468100 \\ \mathrm{C} & 3.582600 & 1.835700 & -2.706000 \\ \mathrm{H} & 4.070600 & 1.575600 & -3.642100 \\ \mathrm{C} & 2.596800 & 1.012800 & -2.153700 \\ \mathrm{H} & 2.300600 & 0.087200 & -2.636800 \\ \mathrm{C} & -2.903900 & 1.637300 & 0.859800 \\ \mathrm{H} & -3.594200 & 2.266900 & 1.437400 \\ \mathrm{H} & -3.460300 & 0.737500 & 0.578300 \\ \mathrm{C} & -2.480700 & 2.361600 & -0.397900 \\ \mathrm{C} & -3.275400 & 3.371300 & -0.959300 \\ \mathrm{H} & -4.190700 & 3.699100 & -0.470200 \\ \mathrm{C} & -1.829300 & 3.587000 & -2.706700 \\ \mathrm{H} & -1.567000 & 4.076500 & -3.641300 \\ \mathrm{H} & -1.6396000 & 2.597500 & -2.156000 \\ \mathrm{H} & -2.300100 & -2.638900 \\ \mathrm{H} & -2.904900 & 0.856800 \\ \mathrm{H} & -1.826100 & -2.710400 \\ \mathrm{H} & -3.596000 & 1.433600 \\ \mathrm{H} & -3.460300 & 0.575200 \\ \mathrm{H} & -2.480800 & -0.401200 \\ \mathrm{H} & -3.271800 & -0.961900 \\ \mathrm{H} & -3600 & -3.645400\end{array}$




$\begin{array}{rrrr}\mathrm{C} & -2.593400 & -1.009700 & -2.160300 \\ \mathrm{H} & -2.292200 & -0.086000 & -2.644000 \\ \mathrm{~N} & 1.750400 & -1.232400 & 1.717000 \\ \mathrm{~N} & 1.228900 & 1.748500 & 1.720800 \\ \mathrm{~N} & -1.751900 & 1.227400 & 1.717400 \\ \mathrm{~N} & -1.230800 & -1.753000 & 1.715300 \\ \mathrm{~N} & 1.338200 & -1.984400 & -1.003300 \\ \mathrm{~N} & 1.985000 & 1.337900 & -0.999700 \\ \mathrm{~N} & -1.337600 & 1.983600 & -1.004000 \\ \mathrm{~N} & -1.981000 & -1.339600 & -1.008000 \\ \mathrm{~N} & -3.977400 & -2.951400 & -2.108000 \\ \mathrm{~N} & 2.965600 & -3.962000 & -2.115500 \\ \mathrm{~N} & 3.968100 & 2.963500 & -2.104900 \\ \mathrm{~N} & -2.956600 & 3.973800 & -2.105200 \\ \mathrm{Bi} & 0.000200 & -0.001400 & 0.214700\end{array}$

Zero-point correction $=$

Thermal correction to Energy=

Thermal correction to Enthalpy=
0.649935 (Hartree/Particle) 0.684258

0.685202

Sum of electronic and zero-point Energies $=\quad-1749.497588$

Sum of electronic and thermal Energies $=\quad-1749.463266$

Sum of electronic and thermal Enthalpies $=\quad-1749.462322$

Sum of electronic and thermal Free Energies $=\quad-1749.561563$

$\mathrm{E}(\mathrm{SCF})$ in SMD Solvation Model $=-1750.66255432$

Table S8. DFT-optimized Cartesian coordinates and energies for [Bi(DOTA) $]^{1-}$

$\begin{array}{lrrr}\mathrm{Bi} & 0.000000 & 0.000000 & 0.597000 \\ \mathrm{~N} & 1.074600 & 1.847700 & -1.166800 \\ \mathrm{C} & 0.000000 & 2.682900 & -1.733200 \\ \mathrm{H} & 0.375800 & 3.290800 & -2.576000 \\ \mathrm{H} & -0.312900 & 3.388200 & -0.961400 \\ \mathrm{C} & -1.215800 & 1.884500 & -2.217000 \\ \mathrm{H} & -1.940300 & 2.592600 & -2.660200 \\ \mathrm{H} & -0.912000 & 1.212400 & -3.027500 \\ \mathrm{~N} & -1.847600 & 1.074500 & -1.166800 \\ \mathrm{C} & -2.682900 & -0.000000 & -1.733100 \\ \mathrm{H} & -3.290900 & 0.375800 & -2.575900 \\ \mathrm{H} & -3.388100 & -0.312800 & -0.961300 \\ \mathrm{C} & 1.884600 & 1.215900 & -2.216900 \\ \mathrm{H} & 2.592900 & 1.940400 & -2.660000 \\ \mathrm{H} & 1.212700 & 0.912100 & -3.027500 \\ \mathrm{C} & 1.880400 & 2.627500 & -0.203100\end{array}$




$\begin{array}{rrrr}\mathrm{H} & 2.297800 & 3.534200 & -0.666900 \\ \mathrm{H} & 2.705500 & 2.003700 & 0.151000 \\ \mathrm{C} & 1.064200 & 3.036600 & 1.054200 \\ \mathrm{O} & 0.140100 & 2.201700 & 1.417900 \\ \mathrm{O} & 1.351100 & 4.098900 & 1.596500 \\ \mathrm{C} & -2.627400 & 1.880500 & -0.203100 \\ \mathrm{H} & -3.534100 & 2.297800 & -0.667000 \\ \mathrm{H} & -2.003500 & 2.705500 & 0.150900 \\ \mathrm{C} & -3.036600 & 1.064300 & 1.054200 \\ \mathrm{O} & -2.201700 & 0.140100 & 1.417800 \\ \mathrm{O} & -4.098800 & 1.351400 & 1.596600 \\ \mathrm{~N} & -1.074600 & -1.847700 & -1.166800 \\ \mathrm{C} & 0.000000 & -2.682900 & -1.733200 \\ \mathrm{H} & -0.375800 & -3.290800 & -2.576000 \\ \mathrm{H} & 0.312900 & -3.388200 & -0.961400 \\ \mathrm{C} & 1.215800 & -1.884500 & -2.217000 \\ \mathrm{H} & 1.940300 & -2.592600 & -2.660200 \\ \mathrm{H} & 0.912000 & -1.212400 & -3.027500 \\ \mathrm{~N} & 1.847600 & -1.074500 & -1.166800 \\ \mathrm{C} & 2.682900 & 0.000000 & -1.733100 \\ \mathrm{C} & 2.627400 & -1.880500 & -0.203100 \\ \mathrm{H} & 3.534100 & -2.297800 & -0.667000 \\ \mathrm{H} & 2.003500 & -2.705500 & 0.150900 \\ \mathrm{C} & 3.036600 & -1.064300 & 1.054200 \\ \mathrm{O} & 2.201700 & -0.140100 & 1.417800 \\ \mathrm{O} & -0.140100 & -2.201700 & 1.417900 \\ \mathrm{C} & -1.064200 & -3.036600 & 1.054200 \\ \mathrm{C} & -1.880400 & -2.627500 & -0.203100 \\ \mathrm{C} & -1.884600 & -1.215900 & -2.216900 \\ \mathrm{H} & -2.592900 & -1.940400 & -2.660000 \\ \mathrm{H} & -1.212700 & -0.912100 & -3.027500 \\ \mathrm{H} & -2.297800 & -3.534200 & -0.666900 \\ \mathrm{H} & -2.705500 & -2.003700 & 0.151000 \\ \mathrm{O} & -1.351100 & -4.098900 & 1.596500 \\ \mathrm{O} & 4.098800 & -1.351400 & 1.596600 \\ \mathrm{H} & 3.290900 & -0.375800 & -2.575900 \\ \mathrm{H} & 3.388100 & 0.312800 & -0.961300\end{array}$

Zero-point correction=

Thermal correction to Energy=

0.425662 (Hartree/Particle)

0.452694

0.453639

Thermal correction to Gibbs Free Energy=

Sum of electronic and zero-point Energies=

0.370871

$-1450.065310$

$-1450.038277$

Sum of electronic and thermal Energies=

$-1450.037333$ 
Sum of electronic and thermal Free Energies= $-1450.120101$

$\mathrm{E}(\mathrm{SCF})$ in SMD Solvation Model $=-1450.62301758$

Table S9. DFT-optimized Cartesian coordinates and energies for [Bi(CHX-DTPA) ${ }^{2-}$

$\begin{array}{lrrr}\mathrm{Bi} & 0.723900 & -0.626700 & 0.319400 \\ \mathrm{O} & 3.036900 & -1.249500 & 0.219900 \\ \mathrm{O} & 5.212000 & -0.645900 & 0.254400 \\ \mathrm{O} & 0.309700 & -0.168300 & -2.045400 \\ \mathrm{O} & 0.834800 & 0.885000 & -3.969900 \\ \mathrm{O} & 1.366100 & 1.074100 & 1.990900 \\ \mathrm{O} & 0.769400 & 2.915200 & 3.159600 \\ \mathrm{O} & 0.199500 & -2.792200 & -0.560000 \\ \mathrm{O} & -1.040800 & -3.952600 & -2.047600 \\ \mathrm{O} & -0.508300 & -1.057700 & 2.392400 \\ \mathrm{O} & -2.348900 & -1.791800 & 3.482800 \\ \mathrm{~N} & 2.321700 & 1.249300 & -0.757900 \\ \mathrm{~N} & -0.633800 & 1.660000 & 0.093900 \\ \mathrm{~N} & -1.917400 & -1.104900 & -0.027000 \\ \mathrm{C} & 1.699600 & 2.560200 & -0.535600 \\ \mathrm{C} & 0.170400 & 2.600200 & -0.730400 \\ \mathrm{C} & -1.946700 & 1.388700 & -0.581900 \\ \mathrm{C} & -2.707200 & 0.156800 & -0.013400 \\ \mathrm{C} & -4.075300 & -0.005200 & -0.723800 \\ \mathrm{C} & -4.950100 & 1.251000 & -0.667900 \\ \mathrm{C} & -4.199900 & 2.431600 & -1.290500 \\ \mathrm{C} & -2.862600 & 2.639700 & -0.571400 \\ \mathrm{C} & 3.603100 & 1.086400 & -0.051500 \\ \mathrm{C} & 4.006000 & -0.401300 & 0.145200 \\ \mathrm{C} & 2.434600 & 0.906900 & -2.181100 \\ \mathrm{C} & 1.079000 & 0.522500 & -2.812700 \\ \mathrm{C} & -0.740400 & 2.130600 & 1.493700 \\ \mathrm{C} & 0.590800 & 2.042800 & 2.299000 \\ \mathrm{C} & -1.927400 & -1.878600 & -1.287000 \\ \mathrm{C} & -0.831300 & -2.985200 & -1.308500 \\ \mathrm{C} & -2.312500 & -1.968100 & 1.106100 \\ \mathrm{C} & -1.688100 & -1.559500 & 2.461600 \\ \mathrm{H} & 2.114900 & 3.311800 & -1.235200 \\ \mathrm{H} & 1.952500 & 2.888600 & 0.471300 \\ \mathrm{H} & -0.135200 & 3.640100 & -0.519500 \\ \mathrm{H} & -0.060300 & 2.408500 & -1.779600 \\ \mathrm{H} & -1.681400 & 1.147900 & -1.616400 \\ \mathrm{H} & -2.916100 & 0.357000 & 1.045000 \\ \mathrm{H} & -3.902400 & -0.259200 & -1.777100\end{array}$




$\begin{array}{rrrr}\mathrm{H} & -4.601900 & -0.857900 & -0.278900 \\ \mathrm{H} & -5.901800 & 1.071800 & -1.189100 \\ \mathrm{H} & -5.202200 & 1.488800 & 0.376700 \\ \mathrm{H} & -4.801000 & 3.351200 & -1.240200 \\ \mathrm{H} & -4.022700 & 2.227900 & -2.357100 \\ \mathrm{H} & -3.071500 & 2.923800 & 0.468700 \\ \mathrm{H} & -2.326400 & 3.483400 & -1.021700 \\ \mathrm{H} & 3.482500 & 1.506900 & 0.951000 \\ \mathrm{H} & 4.427300 & 1.609400 & -0.561900 \\ \mathrm{H} & 3.089200 & 0.032000 & -2.260200 \\ \mathrm{H} & 2.888900 & 1.726200 & -2.762400 \\ \mathrm{H} & -1.455900 & 1.495900 & 2.023600 \\ \mathrm{H} & -1.091300 & 3.171000 & 1.545700 \\ \mathrm{H} & -1.707100 & -1.209100 & -2.121400 \\ \mathrm{H} & -2.893100 & -2.373200 & -1.463200 \\ \mathrm{H} & -3.405900 & -2.025900 & 1.216500 \\ \mathrm{H} & -1.953600 & -2.978600 & 0.892400\end{array}$

Zero-point correction $=$

Thermal correction to Energy=

Thermal correction to Enthalpy=

Thermal correction to Gibbs Free Energy=

Sum of electronic and zero-point Energies=

Sum of electronic and thermal Energies=

Sum of electronic and thermal Enthalpies=

Sum of electronic and thermal Free Energies=
0.439000 (Hartree/Particle)

0.469132

0.470077

$\mathrm{E}(\mathrm{SCF})$ in SMD Solvation Model $=-1622.70250741$

Table S10. DFT-optimized Cartesian coordinates and energies for $\left[\mathrm{La}\left(\mathrm{L}^{\mathrm{py}}\right)\left(\mathrm{OH}_{2}\right)\right]^{3+}$

$\begin{array}{rrrc}\mathrm{O} & -0.000100 & 0.000100 & -2.672500 \\ \mathrm{H} & -0.423900 & -0.650000 & -3.257300 \\ \mathrm{H} & 0.423700 & 0.650200 & -3.257300 \\ \mathrm{~N} & -0.256200 & -2.131500 & 1.760000 \\ \mathrm{~N} & 0.256300 & 2.131400 & 1.760100 \\ \mathrm{~N} & -2.136100 & 0.255100 & 1.778300 \\ \mathrm{~N} & 2.300600 & -1.234100 & -0.875300 \\ \mathrm{~N} & -2.300700 & 1.234100 & -0.875100 \\ \mathrm{~N} & 2.136100 & -0.255200 & 1.778200 \\ \mathrm{~N} & -1.281800 & -2.248500 & -0.885200 \\ \mathrm{~N} & 1.281700 & 2.248500 & -0.885100 \\ \mathrm{C} & 2.079100 & 0.774400 & 2.858800 \\ \mathrm{H} & 3.065500 & 0.882400 & 3.333300 \\ \mathrm{H} & 1.411300 & 0.407000 & 3.640900\end{array}$




$\begin{array}{lrrr}\mathrm{C} & -2.079000 & -0.774500 & 2.858900 \\ \mathrm{H} & -3.065300 & -0.882600 & 3.333500 \\ \mathrm{H} & -1.411100 & -0.407100 & 3.640900 \\ \mathrm{C} & 1.620900 & 2.147000 & 2.374500 \\ \mathrm{H} & 1.647700 & 2.847000 & 3.222100 \\ \mathrm{H} & 2.322100 & 2.535500 & 1.633600 \\ \mathrm{C} & -3.457500 & 0.981300 & -0.217800 \\ \mathrm{C} & -1.620800 & -2.147100 & 2.374500 \\ \mathrm{H} & -2.322000 & -2.535600 & 1.633600 \\ \mathrm{H} & -1.647500 & -2.847200 & 3.222100 \\ \mathrm{C} & -0.772300 & 2.095100 & 2.844400 \\ \mathrm{H} & -0.878800 & 3.091100 & 3.298500 \\ \mathrm{H} & -0.399200 & 1.444600 & 3.637900 \\ \mathrm{C} & 0.772400 & -2.095200 & 2.844300 \\ \mathrm{H} & 0.879000 & -3.091300 & 3.298400 \\ \mathrm{H} & 0.399400 & -1.444700 & 3.637800 \\ \mathrm{C} & 3.384900 & -0.068300 & 0.986900 \\ \mathrm{H} & 4.267600 & -0.227600 & 1.622600 \\ \mathrm{H} & 3.424600 & 0.973500 & 0.650800 \\ \mathrm{C} & 3.531100 & -2.606100 & -2.436600 \\ \mathrm{H} & 3.512000 & -3.248500 & -3.310600 \\ \mathrm{C} & -2.670400 & -3.459700 & -2.448100 \\ \mathrm{H} & -3.339300 & -3.429100 & -3.301700 \\ \mathrm{C} & 3.457500 & -0.981300 & -0.218000 \\ \mathrm{C} & -0.993800 & -3.416000 & -0.262400 \\ \mathrm{C} & 0.993800 & 3.416000 & -0.262300 \\ \mathrm{C} & -3.531200 & 2.606200 & -2.436300 \\ \mathrm{H} & -3.512200 & 3.248600 & -3.310300 \\ \mathrm{C} & 2.670200 & 3.459800 & -2.448000 \\ \mathrm{H} & 3.339100 & 3.429300 & -3.301700 \\ \mathrm{C} & -3.384900 & 0.068300 & 0.987100 \\ \mathrm{H} & -4.267500 & 0.227500 & 1.622900 \\ \mathrm{H} & -3.424500 & -0.973500 & 0.650900 \\ \mathrm{C} & -0.070200 & -3.361500 & 0.938300 \\ \mathrm{H} & -0.220500 & -4.259800 & 1.553900 \\ \mathrm{H} & 0.969600 & -3.388100 & 0.593900 \\ \mathrm{C} & 0.070200 & 3.361500 & 0.938400 \\ \mathrm{H} & 0.220500 & 4.259700 & 1.554100 \\ \mathrm{H} & -0.969600 & 3.388000 & 0.594100 \\ \mathrm{C} & -2.146600 & 1.623800 & 2.382200 \\ \mathrm{H} & -2.834500 & 1.656400 & 3.239800 \\ \mathrm{H} & -2.549600 & 2.315900 & 1.640200 \\ \mathrm{C} & -4.722000 & 2.331500 & -1.761800 \\ \mathrm{H} & -5.663100 & 2.754800 & -2.099600 \\ \mathrm{C} & -1.511300 & -4.636100 & -0.703400\end{array}$




$\begin{array}{lrrr}\mathrm{H} & -1.265400 & -5.552400 & -0.175400 \\ \mathrm{C} & 2.146800 & -1.624000 & 2.382000 \\ \mathrm{H} & 2.834700 & -1.656600 & 3.239600 \\ \mathrm{H} & 2.549700 & -2.316000 & 1.640000 \\ \mathrm{C} & 4.679400 & -1.512800 & -0.633200 \\ \mathrm{H} & 5.584900 & -1.292500 & -0.076300 \\ \mathrm{C} & -4.679400 & 1.512800 & -0.632900 \\ \mathrm{H} & -5.584900 & 1.292500 & -0.075900 \\ \mathrm{C} & 4.721900 & -2.331400 & -1.762200 \\ \mathrm{H} & 5.663000 & -2.754700 & -2.100100 \\ \mathrm{C} & 1.511300 & 4.636200 & -0.703200 \\ \mathrm{H} & 1.265400 & 5.552400 & -0.175200 \\ \mathrm{C} & 2.120800 & 2.285900 & -1.945900 \\ \mathrm{H} & 2.375800 & 1.326100 & -2.388800 \\ \mathrm{C} & -2.120900 & -2.285800 & -1.945800 \\ \mathrm{H} & -2.375900 & -1.326000 & -2.388800 \\ \mathrm{C} & 2.354500 & -2.039900 & -1.958900 \\ \mathrm{H} & 1.410700 & -2.233400 & -2.457700 \\ \mathrm{C} & -2.350200 & -4.664100 & -1.817300 \\ \mathrm{H} & -2.760100 & -5.604200 & -2.174000 \\ \mathrm{C} & 2.350100 & 4.664200 & -1.817200 \\ \mathrm{H} & 2.760000 & 5.604300 & -2.173900 \\ \mathrm{C} & -2.354600 & 2.040000 & -1.958700 \\ \mathrm{H} & -1.410900 & 2.233500 & -2.457600 \\ \mathrm{La} & 0.000000 & 0.000000 & 0.007600\end{array}$

Zero-point correction $=$

Thermal correction to Energy=

Thermal correction to Enthalpy=

Thermal correction to Gibbs Free Energy=

Sum of electronic and zero-point Energies $=$

Sum of electronic and thermal Energies=

Sum of electronic and thermal Enthalpies=

Sum of electronic and thermal Free Energies=
0.722039 (Hartree/Particle)

0.760165

0.761109

0.654357

$-2192.244322$

$-2192.206196$

$-2192.205252$

$-2192.312003$

$\mathrm{E}(\mathrm{SCF})$ in SMD Solvation Model= -2193.43670489

Table S11. DFT-optimized Cartesian coordinates and energies for $\left[\mathrm{La}\left(\mathrm{L}^{\mathrm{pyd}}\right)\left(\mathrm{OH}_{2}\right)\right]^{3+}$

$\begin{array}{lrrr}\mathrm{O} & -0.078100 & -0.219400 & -2.492700 \\ \mathrm{H} & 0.401100 & -1.051300 & -2.735600 \\ \mathrm{H} & -1.008200 & -0.332600 & -2.801200 \\ \mathrm{La} & -0.010300 & 0.008400 & -0.016200 \\ \mathrm{~N} & 1.526600 & -1.385200 & 1.916000 \\ \mathrm{~N} & -1.775900 & 1.449800 & 1.687500\end{array}$




\begin{tabular}{|c|c|c|c|}
\hline N & -1.563800 & -1.626500 & 1.764800 \\
\hline $\mathbf{v}$ & 2.258400 & 1.215200 & -0.678100 \\
\hline & -2.206000 & -1.455200 & -0.956400 \\
\hline$v$ & 1.280200 & 1.692700 & 1.855200 \\
\hline & 1.530000 & -2.115100 & -0.813900 \\
\hline$y$ & -1.203800 & 2.241100 & -0.890300 \\
\hline & 0.328300 & 2.229900 & 2.871600 \\
\hline I & 0.751400 & 3.120200 & 3.359900 \\
\hline $\mathrm{H}$ & 0.221000 & 1.483400 & 3.661100 \\
\hline $\mathcal{C}$ & -0.709100 & -2.104600 & 2.891100 \\
\hline $\mathrm{H}$ & -1.178100 & -2.966700 & 3.388200 \\
\hline $\mathrm{H}$ & -0.667800 & -1.316400 & 3.644600 \\
\hline 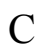 & -1.042000 & 2.597700 & 2.307800 \\
\hline $\mathrm{H}$ & -1.643500 & 3.038000 & 3.116900 \\
\hline $\mathrm{H}$ & -0.933200 & 4500 & 1.548100 \\
\hline $\mathrm{C}$ & -2.765900 & -2.457000 & -0.271300 \\
\hline $\mathrm{C}$ & 0.703700 & -2.504900 & 2.470200 \\
\hline $\mathrm{H}$ & 0.659200 & -3.287300 & 1.7 \\
\hline $\mathrm{H}$ & 1.209300 & -2.950100 & 3.340500 \\
\hline $\mathrm{C}$ & -2.344800 & 0.580200 & 2.756400 \\
\hline $\mathrm{H}$ & -3.242100 & 1.044300 & 3.192600 \\
\hline $\mathrm{H}$ & -1.616400 & 0.524500 & $3.56^{\circ}$ \\
\hline $\mathrm{C}$ & 1.949200 & -0.462900 & 3.0 \\
\hline $\mathrm{H}$ & 2.783800 & -0.902700 & 3.580000 \\
\hline $\mathrm{H}$ & 1.124000 & -0.378700 & 3.723 \\
\hline C & 1.891100 & 2.823500 & 1.102400 \\
\hline $\mathrm{H}$ & 2.556600 & 3.408800 & 1.754800 \\
\hline $\mathrm{H}$ & 1.092400 & 3.502600 & 0.785000 \\
\hline $\mathrm{C}$ & 2.648800 & 2.372200 & -0.128900 \\
\hline $\mathrm{C}$ & 2.500700 & -2.628400 & -0.051800 \\
\hline $\mathrm{C}$ & -2.362700 & 2.695800 & -0.393300 \\
\hline $\mathrm{C}$ & -2.118000 & -2.807700 & 1.050200 \\
\hline $\mathrm{H}$ & -2.838000 & -3.341800 & 1.687800 \\
\hline $\mathrm{H}$ & -1.302000 & -3.511400 & 0.849700 \\
\hline $\mathrm{C}$ & 2.743300 & -1.969600 & 1.289300 \\
\hline $\mathrm{H}$ & 3.221200 & -2.685700 & 1.973900 \\
\hline $\mathrm{H}$ & 3.469600 & -1.165500 & 1.127300 \\
\hline $\mathrm{C}$ & -2.877900 & 1.990400 & 0.843900 \\
\hline $\mathrm{H}$ & -3.512600 & 2.676600 & 1.424600 \\
\hline $\mathrm{H}$ & -3.522000 & 1.159900 & 0.533800 \\
\hline $\mathrm{C}$ & -2.713400 & -0.824900 & 2.289100 \\
\hline $\mathrm{H}$ & -3.191400 & -1.353100 & 3.127900 \\
\hline $\mathrm{H}$ & -3.463100 & -0.767200 & 1.495800 \\
\hline $\mathrm{C}$ & -4.339800 & -2.821500 & -2.029000 \\
\hline & -5.182200 & -3.330200 & -2.487000 \\
\hline
\end{tabular}




$\begin{array}{lrrr}\mathrm{C} & 3.319100 & -3.675700 & -0.513700 \\ \mathrm{H} & 4.095100 & -4.093000 & 0.121200 \\ \mathrm{C} & 2.369900 & 0.924900 & 2.534600 \\ \mathrm{H} & 2.748100 & 1.489800 & 3.399600 \\ \mathrm{H} & 3.203600 & 0.840300 & 1.833800 \\ \mathrm{C} & 3.687300 & 3.132200 & -0.690000 \\ \mathrm{H} & 4.005100 & 4.064400 & -0.232300 \\ \mathrm{C} & -3.859000 & -3.179300 & -0.783400 \\ \mathrm{H} & -4.303600 & -3.989500 & -0.213100 \\ \mathrm{C} & 4.282800 & 2.646500 & -1.839600 \\ \mathrm{H} & 5.088800 & 3.179300 & -2.334400 \\ \mathrm{C} & -3.050500 & 3.758400 & -0.999300 \\ \mathrm{H} & -3.986700 & 4.122900 & -0.586900 \\ \mathrm{C} & 3.105800 & -4.143500 & -1.796200 \\ \mathrm{H} & 3.697600 & -4.949000 & -2.219400 \\ \mathrm{C} & -2.485900 & 4.321000 & -2.130200 \\ \mathrm{H} & -2.959400 & 5.144400 & -2.656000 \\ \mathrm{C} & -1.256500 & 3.802400 & -2.571800 \\ \mathrm{H} & -0.746200 & 4.208800 & -3.440000 \\ \mathrm{C} & -3.689700 & -1.769500 & -2.696800 \\ \mathrm{H} & -3.997900 & -1.440800 & -3.684900 \\ \mathrm{C} & 3.819400 & 1.420100 & -2.346200 \\ \mathrm{H} & 4.250300 & 0.974800 & -3.237900 \\ \mathrm{C} & 2.091600 & -3.528300 & -2.549600 \\ \mathrm{H} & 1.878800 & -3.822500 & -3.572900 \\ \mathrm{~N} & 2.840600 & 0.723100 & -1.777200 \\ \mathrm{~N} & -0.633700 & 2.794400 & -1.966800 \\ \mathrm{~N} & -2.657100 & -1.117300 & -2.171700 \\ \mathrm{~N} & 1.332500 & -2.552600 & -2.063500\end{array}$

Zero-point correction $=$

Thermal correction to Energy=

Thermal correction to Enthalpy=
0.673191 (Hartree/Particle)

0.709931

0.710875

0.606795

$-2256.333403$

$-2256.296664$

$-2256.295719$

$-2256.399799$

$\mathrm{E}(\mathrm{SCF})$ in SMD Solvation Model $=-2257.47747876$

Table S12. DFT-optimized Cartesian coordinates and energies for $\left[\mathrm{La}\left(\mathrm{L}^{\mathrm{pyr}}\right)\left(\mathrm{OH}_{2}\right)\right]^{3+}$

$\begin{array}{llll}\mathrm{O} & -0.000100 & 0.000100 & -2.685900\end{array}$

$\mathrm{H} \quad-0.504300 \quad-0.584100 \quad-3.278200$ 


$\begin{array}{rrrr}\mathrm{H} & 0.504200 & 0.584300 & -3.278200 \\ \mathrm{~N} & -0.529600 & -2.091500 & 1.763500 \\ \mathrm{~N} & 0.529700 & 2.091400 & 1.763600 \\ \mathrm{~N} & -2.095400 & 0.529100 & 1.778100 \\ \mathrm{~N} & 2.131600 & -1.495900 & -0.866300 \\ \mathrm{~N} & -2.131600 & 1.495900 & -0.866100 \\ \mathrm{~N} & 2.095400 & -0.529200 & 1.777900 \\ \mathrm{~N} & -1.539000 & -2.086600 & -0.870200 \\ \mathrm{~N} & 1.539000 & 2.086700 & -0.870200 \\ \mathrm{C} & 2.163500 & 0.499700 & 2.860800 \\ \mathrm{H} & 3.152200 & 0.481700 & 3.341800 \\ \mathrm{H} & 1.450200 & 0.219900 & 3.638500 \\ \mathrm{C} & -2.163400 & -0.499900 & 2.860900 \\ \mathrm{H} & -3.152100 & -0.481900 & 3.341900 \\ \mathrm{H} & -1.450000 & -0.220100 & 3.638600 \\ \mathrm{C} & 1.886600 & 1.920700 & 2.378500 \\ \mathrm{H} & 2.004200 & 2.608700 & 3.228000 \\ \mathrm{H} & 2.633600 & 2.218000 & 1.639600 \\ \mathrm{C} & -3.320100 & 1.394300 & -0.220800 \\ \mathrm{C} & -1.886500 & -1.920900 & 2.378400 \\ \mathrm{H} & -2.633600 & -2.218100 & 1.639500 \\ \mathrm{H} & -2.004100 & -2.608800 & 3.227900 \\ \mathrm{C} & -0.497600 & 2.176300 & 2.848400 \\ \mathrm{H} & -0.477300 & 3.172800 & 3.312800 \\ \mathrm{H} & -0.212800 & 1.475900 & 3.635700 \\ \mathrm{C} & 0.497700 & -2.176500 & 2.848200 \\ \mathrm{H} & 0.477400 & -3.173000 & 3.312600 \\ \mathrm{H} & 0.213000 & -1.476100 & 3.635600 \\ \mathrm{C} & 3.371200 & -0.515100 & 1.008300 \\ \mathrm{H} & 4.211100 & -0.822300 & 1.647600 \\ \mathrm{H} & 3.579300 & 0.513800 & 0.694600 \\ \mathrm{C} & 3.320100 & -1.394300 & -0.221000 \\ \mathrm{C} & -1.408800 & -3.286800 & -0.251000 \\ \mathrm{C} & 1.408800 & 3.286800 & -0.250900 \\ \mathrm{C} & -3.371200 & 0.515100 & 1.008400 \\ \mathrm{H} & -4.211000 & 0.822200 & 1.647900 \\ \mathrm{H} & -3.579300 & -0.513900 & 0.694700 \\ \mathrm{H} & -0.515100 & -3.352500 & 0.968900 \\ \mathrm{H} & 0.512500 & -4.207300 & 1.593800 \\ \mathrm{H} & -3.546600 & 0.641500 \\ \mathrm{H} & -510700 & 4.207200 & 1.594000 \\ \mathrm{H} & -3.3500 & 3.546600 & 0.641700 \\ \mathrm{H} & 1.889500 & 2.381900 \\ \mathrm{H} & 2.012700 & 3.238000\end{array}$




$\begin{array}{lrrr}\mathrm{H} & -2.228700 & 2.629300 & 1.639900 \\ \mathrm{C} & -4.309100 & 2.826700 & -1.850600 \\ \mathrm{H} & -5.150100 & 3.368600 & -2.276900 \\ \mathrm{C} & -2.066000 & -4.414400 & -0.737200 \\ \mathrm{H} & -1.974300 & -5.378500 & -0.247200 \\ \mathrm{C} & 1.920900 & -1.889700 & 2.381700 \\ \mathrm{H} & 2.600000 & -2.012900 & 3.237800 \\ \mathrm{H} & 2.228800 & -2.629400 & 1.639600 \\ \mathrm{C} & 4.450100 & -2.056500 & -0.693200 \\ \mathrm{H} & 5.404500 & -1.984400 & -0.181700 \\ \mathrm{C} & -4.450100 & 2.056600 & -0.692900 \\ \mathrm{H} & -5.404500 & 1.984500 & -0.181300 \\ \mathrm{C} & 4.309000 & -2.826600 & -1.851000 \\ \mathrm{H} & 5.150000 & -3.368500 & -2.277300 \\ \mathrm{C} & 2.066000 & 4.414500 & -0.737100 \\ \mathrm{H} & 1.974300 & 5.378500 & -0.247000 \\ \mathrm{C} & 2.358300 & 2.051400 & -1.944200 \\ \mathrm{H} & 2.508400 & 1.078600 & -2.409100 \\ \mathrm{C} & -2.358400 & -2.051300 & -1.944200 \\ \mathrm{H} & -2.508500 & -1.078400 & -2.409100 \\ \mathrm{C} & 2.111900 & -2.281500 & -1.965500 \\ \mathrm{H} & 1.158900 & -2.376400 & -2.476800 \\ \mathrm{C} & -2.854600 & -4.260900 & -1.881000 \\ \mathrm{H} & -3.384400 & -5.102100 & -2.321800 \\ \mathrm{C} & 2.854500 & 4.261000 & -1.880900 \\ \mathrm{H} & 3.384300 & 5.102200 & -2.321700 \\ \mathrm{C} & -2.112000 & 2.281600 & -1.965300 \\ \mathrm{H} & -1.159000 & 2.376500 & -2.476600 \\ \mathrm{~N} & 3.010800 & 3.070500 & -2.478400 \\ \mathrm{~N} & -3.132800 & 2.946100 & -2.482600 \\ \mathrm{~N} & -3.010900 & -3.070400 & -2.478500 \\ \mathrm{~N} & 3.132700 & -2.946000 & -2.482900 \\ \mathrm{La} & -0.000000 & -0.000000 & 0.012500\end{array}$

Zero-point correction $=$

Thermal correction to Energy=

0.674225 (Hartree/Particle)

Thermal correction to Enthalpy=

0.711897

0.712841

Thermal correction to Gibbs Free Energy $=\quad 0.606789$

Sum of electronic and zero-point Energies $=\quad-2256.397615$

Sum of electronic and thermal Energies $=\quad-2256.359943$

Sum of electronic and thermal Enthalpies $=\quad-2256.358998$

Sum of electronic and thermal Free Energies $=\quad-2256.465051$

$\mathrm{E}(\mathrm{SCF})$ in SMD Solvation Model= -2257.59923093 
Table S13. DFT-optimized Cartesian coordinates and energies for $\left[\mathrm{La}\left(\mathrm{L}^{\mathrm{pz}}\right)\left(\mathrm{OH}_{2}\right)\right]^{3+}$

$\begin{array}{rrrr}\mathrm{O} & -0.000100 & 0.000100 & -2.666000 \\ \mathrm{H} & -0.478100 & -0.609000 & -3.254200 \\ \mathrm{H} & 0.478000 & 0.609200 & -3.254100 \\ \mathrm{~N} & -0.463900 & -2.101400 & 1.748700 \\ \mathrm{~N} & 0.464000 & 2.101300 & 1.748800 \\ \mathrm{~N} & -2.106600 & 0.463400 & 1.766600 \\ \mathrm{~N} & 2.191700 & -1.440700 & -0.897600 \\ \mathrm{~N} & -2.191800 & 1.440800 & -0.897400 \\ \mathrm{~N} & 2.106700 & -0.463500 & 1.766400 \\ \mathrm{~N} & -1.490900 & -2.135700 & -0.904300 \\ \mathrm{~N} & 1.490800 & 2.135700 & -0.904200 \\ \mathrm{C} & 2.146500 & 0.567500 & 2.849900 \\ \mathrm{H} & 3.137100 & 0.579000 & 3.326700 \\ \mathrm{H} & 1.444800 & 0.265400 & 3.630000 \\ \mathrm{C} & -2.146300 & -0.567600 & 2.849900 \\ \mathrm{H} & -3.136900 & -0.579200 & 3.326900 \\ \mathrm{H} & -1.444600 & -0.265600 & 3.630000 \\ \mathrm{C} & 1.825100 & 1.978700 & 2.366900 \\ \mathrm{H} & 1.916800 & 2.670800 & 3.216000 \\ \mathrm{H} & 2.563500 & 2.301000 & 1.630000 \\ \mathrm{C} & -3.356400 & 1.299200 & -0.227900 \\ \mathrm{C} & -1.825000 & -1.978800 & 2.366900 \\ \mathrm{H} & -2.563500 & -2.301100 & 1.630000 \\ \mathrm{H} & -1.916600 & -2.671000 & 3.215900 \\ \mathrm{C} & -0.565100 & 2.162000 & 2.834900 \\ \mathrm{H} & -0.573800 & 3.162000 & 3.291700 \\ \mathrm{H} & -0.257000 & 1.476200 & 3.626400 \\ \mathrm{C} & 0.565200 & -2.162200 & 2.834800 \\ \mathrm{H} & 0.574000 & -3.162200 & 3.291500 \\ \mathrm{H} & 0.257200 & -1.476300 & 3.626300 \\ \mathrm{C} & 3.378500 & -0.404800 & 0.989100 \\ \mathrm{H} & 4.231500 & -0.674400 & 1.628100 \\ \mathrm{H} & 3.543900 & 0.631000 & 0.672700 \\ \mathrm{C} & 3.356400 & -1.299200 & -0.228100 \\ \mathrm{C} & -1.315800 & -3.313500 & -0.267200 \\ \mathrm{C} & 1.315800 & 3.313500 & -0.267100 \\ \mathrm{C} & -3.378500 & 0.404800 & 0.989300 \\ \mathrm{H} & -4.231400 & 0.674300 & 1.628400 \\ \mathrm{H} & -3.543900 & -0.631000 & 0.672900 \\ \mathrm{C} & -0.405400 & -3.354400 & 0.940200 \\ \mathrm{H} & -0.662100 & -4.225100 & 1.560400 \\ \mathrm{H} & 0.628500 & -3.503800 & 0.609100 \\ \mathrm{C} & 0.405400 & 3.354300 & 0.940400\end{array}$




$\begin{array}{lrrr}\mathrm{H} & 0.662100 & 4.225000 & 1.560600 \\ \mathrm{H} & -0.628500 & 3.503800 & 0.609300 \\ \mathrm{C} & -1.978900 & 1.828700 & 2.372200 \\ \mathrm{H} & -2.659700 & 1.926600 & 3.230000 \\ \mathrm{H} & -2.314600 & 2.558400 & 1.632500 \\ \mathrm{C} & -1.964800 & -4.470000 & -0.727500 \\ \mathrm{H} & -1.835000 & -5.421900 & -0.216200 \\ \mathrm{C} & 1.979000 & -1.828800 & 2.372000 \\ \mathrm{H} & 2.659800 & -1.926700 & 3.229700 \\ \mathrm{H} & 2.314700 & -2.558500 & 1.632300 \\ \mathrm{C} & 4.514800 & -1.954100 & -0.670700 \\ \mathrm{H} & 5.454400 & -1.849200 & -0.131800 \\ \mathrm{C} & -4.514800 & 1.954100 & -0.670300 \\ \mathrm{H} & -5.454400 & 1.849200 & -0.131400 \\ \mathrm{C} & 1.964800 & 4.470100 & -0.727400 \\ \mathrm{H} & 1.834900 & 5.421900 & -0.216000 \\ \mathrm{C} & 2.951100 & 3.295300 & -2.410700 \\ \mathrm{H} & 3.618400 & 3.283100 & -3.269000 \\ \mathrm{C} & -3.372500 & 2.876400 & -2.409800 \\ \mathrm{H} & -3.373500 & 3.517500 & -3.287700 \\ \mathrm{C} & 3.372400 & -2.876200 & -2.410100 \\ \mathrm{H} & 3.373400 & -3.517300 & -3.288100 \\ \mathrm{C} & -2.951200 & -3.295100 & -2.410800 \\ \mathrm{H} & -3.618500 & -3.283000 & -3.269000 \\ \mathrm{C} & -2.206700 & 2.236700 & -1.985100 \\ \mathrm{H} & -1.273600 & 2.363000 & -2.523200 \\ \mathrm{C} & 2.323000 & 2.131000 & -1.966500 \\ \mathrm{H} & 2.507600 & 1.176100 & -2.452200 \\ \mathrm{C} & 2.206600 & -2.236600 & -1.985300 \\ \mathrm{H} & 1.273400 & -2.362900 & -2.523400 \\ \mathrm{C} & -2.323100 & -2.130900 & -1.966500 \\ \mathrm{H} & -2.507700 & -1.176000 & -2.452100 \\ \mathrm{~N} & 4.526900 & -2.730300 & -1.754600 \\ \mathrm{~N} & 2.764000 & 4.465700 & -1.793600 \\ \mathrm{~N} & -4.527000 & 2.730400 & -1.754200 \\ \mathrm{~N} & -2.764100 & -4.465600 & -1.793800 \\ \mathrm{La} & -0.000000 & -0.000000 & 0.016100\end{array}$

Zero-point correction $=$

Thermal correction to Energy=

Thermal correction to Enthalpy=

Thermal correction to Gibbs Free Energy=

Sum of electronic and zero-point Energies=

Sum of electronic and thermal Energies=

Sum of electronic and thermal Enthalpies=
0.673175 (Hartree/Particle)

0.710849

0.711793

0.605684

$-2256.351134$

$-2256.313459$

$-2256.312515$ 
Sum of electronic and thermal Free Energies $=\quad-2256.418624$

$\mathrm{E}(\mathrm{SCF})$ in SMD Solvation Model $=-2257.56672330$

Table S14. DFT-optimized Cartesian coordinates and energies for $\left[\mathrm{La}(\mathrm{DOTA})\left(\mathrm{OH}_{2}\right)\right]^{1-}$

$\begin{array}{rrrr}\mathrm{N} & 0.847000 & 1.906200 & 1.305600 \\ \mathrm{~N} & -1.135900 & -1.908300 & 1.156900 \\ \mathrm{~N} & 1.757500 & -0.990600 & 1.407400 \\ \mathrm{~N} & -2.046900 & 0.994800 & 1.071200 \\ \mathrm{O} & 1.946400 & 1.467700 & -1.176700 \\ \mathrm{O} & 1.614800 & -1.838500 & -1.198600 \\ \mathrm{O} & -1.719400 & -1.505500 & -1.488100 \\ \mathrm{O} & -1.387800 & 1.832600 & -1.442400 \\ \mathrm{O} & -3.398600 & 2.850300 & -1.669400 \\ \mathrm{O} & 2.899100 & 3.519900 & -1.161000 \\ \mathrm{O} & -2.741100 & -3.523400 & -1.605100 \\ \mathrm{O} & 3.705100 & -2.699400 & -1.102500 \\ \mathrm{C} & 2.778700 & -2.027200 & -0.660000 \\ \mathrm{C} & 3.007300 & -1.253800 & 0.662600 \\ \mathrm{C} & 1.970700 & -0.014700 & 2.488400 \\ \mathrm{C} & 1.227300 & -2.265000 & 1.931300 \\ \mathrm{C} & -0.258000 & -2.222300 & 2.295800 \\ \mathrm{C} & 2.062300 & 1.431800 & 1.997500 \\ \mathrm{C} & 2.118900 & 2.675700 & -0.734800 \\ \mathrm{C} & 1.187800 & 3.061400 & 0.444400 \\ \mathrm{C} & -0.210700 & 2.237200 & 2.276000 \\ \mathrm{C} & -1.617200 & 2.272600 & 1.675800 \\ \mathrm{C} & -3.128000 & 1.255600 & 0.093500 \\ \mathrm{C} & -2.453500 & 0.026200 & 2.101800 \\ \mathrm{C} & -2.620000 & 2.077000 & -1.122800 \\ \mathrm{C} & -2.454300 & -1.425500 & 1.616800 \\ \mathrm{C} & -1.324200 & -3.078000 & 0.268800 \\ \mathrm{C} & -2.015400 & -2.694500 & -1.066900 \\ \mathrm{H} & 3.738000 & -1.799700 & 1.281100 \\ \mathrm{H} & 3.455600 & -0.295900 & 0.381300 \\ \mathrm{H} & 2.891200 & -0.248500 & 3.055600 \\ \mathrm{H} & 1.145900 & -0.106500 & 3.202200 \\ \mathrm{H} & 1.797900 & -2.592200 & 2.820500 \\ \mathrm{H} & 1.387500 & -3.023900 & 1.163100 \\ \mathrm{H} & -0.531900 & -3.193600 & 2.748200 \\ \mathrm{H} & -0.423700 & -1.470100 & 3.074000 \\ \mathrm{H} & 2.301600 & 2.080300 & 2.860700 \\ \mathrm{H} & 2.897900 & 1.525900 & 1.301800 \\ \mathrm{H} & 1.656500 & 3.872500 & 1.024300\end{array}$




$\begin{array}{lrrr}\mathrm{H} & 0.265700 & 3.448100 & -0.001500 \\ \mathrm{H} & -0.013300 & 3.214800 & 2.754400 \\ \mathrm{H} & -0.178400 & 1.496300 & 3.081300 \\ \mathrm{H} & -2.324300 & 2.591900 & 2.463800 \\ \mathrm{H} & -1.659000 & 3.037000 & 0.898000 \\ \mathrm{H} & -3.977100 & 1.779900 & 0.560500 \\ \mathrm{H} & -3.489200 & 0.298200 & -0.295800 \\ \mathrm{H} & -3.462200 & 0.262000 & 2.489600 \\ \mathrm{H} & -1.772200 & 0.127200 & 2.953300 \\ \mathrm{H} & -2.844800 & -2.065700 & 2.429300 \\ \mathrm{H} & -3.151300 & -1.527300 & 0.782900 \\ \mathrm{H} & -1.902800 & -3.872800 & 0.766200 \\ \mathrm{H} & -0.340700 & -3.483600 & 0.010100 \\ \mathrm{La} & -0.006900 & -0.003000 & -0.765000 \\ \mathrm{H} & 1.722400 & 0.598900 & -2.916200 \\ \mathrm{H} & 1.523200 & -0.934500 & -2.961200 \\ \mathrm{O} & 1.094100 & -0.091500 & -3.220600\end{array}$

Zero-point correction $=$

Thermal correction to Energy=

Thermal correction to Enthalpy=

Thermal correction to Gibbs Free Energy=

Sum of electronic and zero-point Energies=

Sum of electronic and thermal Energies=

Sum of electronic and thermal Enthalpies=

Sum of electronic and thermal Free Energies=
0.451448 (Hartree/Particle)

0.480878

0.481823

0.393508

$-1956.951495$

$-1956.922064$

$-1956.921120$

$-1957.009434$

$\mathrm{E}(\mathrm{SCF})$ in SMD Solvation Model $=-1957.55114800$

Table S15. DFT-optimized Cartesian coordinates and energies for $\left[\mathrm{La}(\mathrm{CHX}-\mathrm{DTPA})\left(\mathrm{OH}_{2}\right)\right]^{2-}$

$\begin{array}{lrrr}\mathrm{La} & -0.901700 & 0.808300 & 0.144400 \\ \mathrm{O} & -3.275400 & 1.015700 & -0.269800 \\ \mathrm{O} & -5.429200 & 0.322800 & -0.320500 \\ \mathrm{O} & -0.483300 & -0.348100 & -2.014600 \\ \mathrm{O} & -0.654000 & -2.079500 & -3.455600 \\ \mathrm{O} & -1.332900 & -0.424700 & 2.210200 \\ \mathrm{O} & -0.795400 & -1.876900 & 3.858200 \\ \mathrm{O} & 0.012000 & 2.632800 & -1.285300 \\ \mathrm{O} & 1.367600 & 3.335700 & -2.950500 \\ \mathrm{O} & 0.624000 & 1.845200 & 1.938400 \\ \mathrm{O} & 2.584900 & 2.514100 & 2.851700 \\ \mathrm{~N} & -2.388600 & -1.573100 & -0.392100 \\ \mathrm{~N} & 0.587900 & -1.631200 & 0.549600 \\ \mathrm{~N} & 1.998600 & 0.961300 & -0.337500\end{array}$




\begin{tabular}{|c|c|c|c|}
\hline $\mathrm{C}$ & -1.738800 & -2.706000 & 0.272400 \\
\hline $\mathrm{C}$ & -0.217000 & -2.785600 & 0.072200 \\
\hline & 1.890100 & -1.602100 & -0.200200 \\
\hline 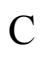 & 2.720200 & -0.301300 & -0.010900 \\
\hline & 4.069400 & -0.412800 & -0.772400 \\
\hline$C$ & 4.902900 & -1.635500 & -0.381000 \\
\hline $\mathrm{C}$ & 4.089800 & -2.906000 & -0.634300 \\
\hline $\mathrm{C}$ & 2.766600 & -2.841700 & 0.134800 \\
\hline $\mathrm{C}$ & -3.727400 & -1.296800 & 50300 \\
\hline $\mathrm{C}$ & -4.216200 & 0.135900 & -0.194300 \\
\hline $\mathrm{C}$ & -2.415600 & -1.725500 & 55400 \\
\hline $\mathrm{C}$ & -1.063100 & -1.378500 & -2.520700 \\
\hline$C$ & 0.719700 & -1.659700 & 2.023500 \\
\hline $\mathrm{C}$ & -0.591700 & -1.302800 & 33400 \\
\hline$C$ & 2.001100 & 57900 & -1.763700 \\
\hline $\mathrm{C}$ & 1.059100 & 2.562300 & 1200 \\
\hline $\mathrm{C}$ & 2.521900 & 2.055900 & 0.505600 \\
\hline $\mathrm{C}$ & 1.881200 & 2.132100 & 0400 \\
\hline $\mathrm{H}$ & -2.145900 & -3.667900 & -0.103100 \\
\hline $\mathrm{H}$ & -1.975100 & -2.658700 & 5400 \\
\hline $\mathrm{H}$ & 0.105000 & -3.711700 & 0.581600 \\
\hline $\mathrm{H}$ & -0.009100 & -2.925200 & -0.5 \\
\hline $\mathrm{H}$ & 1.602800 & -1.647900 & -1.256400 \\
\hline $\mathrm{H}$ & 2.965000 & -0.223400 & 6300 \\
\hline $\mathrm{H}$ & 3.868300 & -0.464900 & 50000 \\
\hline $\mathrm{H}$ & 4.641600 & 0.507800 & 6900 \\
\hline $\mathrm{H}$ & 5.844700 & -1.649900 & 49000 \\
\hline $\mathrm{H}$ & 5.176500 & -1.581100 & 0.683600 \\
\hline $\mathrm{H}$ & 4.653700 & -3.802700 & 37900 \\
\hline $\mathrm{H}$ & 3.890900 & -3.000200 & -1.712300 \\
\hline $\mathrm{H}$ & 2.993200 & -2.837200 & 1.209900 \\
\hline $\mathrm{H}$ & 2.189400 & -3.753300 & -0.055300 \\
\hline $\mathrm{H}$ & -3.658700 & -1.351000 & 1.242700 \\
\hline $\mathrm{H}$ & -4.479700 & -2.029400 & -0.187000 \\
\hline $\mathrm{H}$ & -3.155900 & -1.020600 & -2.250000 \\
\hline $\mathrm{H}$ & -2.726100 & -2.741800 & -2.153000 \\
\hline $\mathrm{H}$ & 1.455200 & -0.907600 & 2.326100 \\
\hline $\mathrm{H}$ & 1.061100 & -2.639100 & 2.392200 \\
\hline $\mathrm{H}$ & 1.624100 & 0.522900 & -2.362000 \\
\hline $\mathrm{H}$ & 3.000000 & 1.642300 & -2.125200 \\
\hline $\mathrm{H}$ & 3.617100 & 2.018900 & 0.611300 \\
\hline $\mathrm{H}$ & 2.285300 & 3.004700 & 0.013800 \\
\hline $\mathrm{H}$ & -0.556600 & 3.240400 & 1.544200 \\
\hline & -0.827800 & 3.650000 & 0.084300 \\
\hline & -1.286100 & 3.502200 & 0.939600 \\
\hline
\end{tabular}


Zero-point correction $=$

Thermal correction to Energy=

Thermal correction to Enthalpy=

Thermal correction to Gibbs Free Energy=

Sum of electronic and zero-point Energies=

Sum of electronic and thermal Energies=

Sum of electronic and thermal Enthalpies=

Sum of electronic and thermal Free Energies=
0.464379 (Hartree/Particle)

0.496939

0.497884

0.401433

$-2128.875952$

$-2128.843392$

$-2128.842448$

$-2128.938898$

$\mathrm{E}(\mathrm{SCF})$ in SMD Solvation Model $=-2129.63005426$

Table S16. DFT-optimized Cartesian coordinates and energies for $\left[\mathrm{Ac}\left(\mathrm{L}^{\mathrm{py}}\right)\left(\mathrm{OH}_{2}\right)\right]^{3+}$

$\begin{array}{rrrr}\mathrm{O} & 0.000300 & -0.000300 & -2.848200 \\ \mathrm{H} & 0.570000 & 0.523600 & -3.437200 \\ \mathrm{H} & -0.569700 & -0.524000 & -3.437000 \\ \mathrm{~N} & 0.554100 & 2.097300 & 1.775100 \\ \mathrm{~N} & -0.554200 & -2.097100 & 1.775100 \\ \mathrm{~N} & 2.100900 & -0.554100 & 1.789400 \\ \mathrm{~N} & -2.221800 & 1.532200 & -0.896700 \\ \mathrm{~N} & 2.221800 & -1.532500 & -0.896400 \\ \mathrm{~N} & -2.101000 & 0.554200 & 1.789200 \\ \mathrm{~N} & 1.600000 & 2.163800 & -0.886800 \\ \mathrm{~N} & -1.600000 & -2.163700 & -0.886700 \\ \mathrm{C} & -2.164900 & -0.476100 & 2.869300 \\ \mathrm{H} & -3.149100 & -0.450800 & 3.360300 \\ \mathrm{H} & -1.442000 & -0.203300 & 3.640700 \\ \mathrm{C} & 2.164800 & 0.476300 & 2.869400 \\ \mathrm{H} & 3.148900 & 0.450900 & 3.360500 \\ \mathrm{H} & 1.441800 & 0.203500 & 3.640700 \\ \mathrm{C} & -1.905400 & -1.903800 & 2.389500 \\ \mathrm{H} & -2.034000 & -2.586000 & 3.242700 \\ \mathrm{H} & -2.655800 & -2.193000 & 1.651000 \\ \mathrm{C} & 3.370500 & -1.453900 & -0.183200 \\ \mathrm{C} & 1.905300 & 1.903900 & 2.389500 \\ \mathrm{H} & 2.655700 & 2.193100 & 1.651000 \\ \mathrm{H} & 2.033900 & 2.586200 & 3.242700 \\ \mathrm{C} & 0.476500 & -2.182100 & 2.855000 \\ \mathrm{H} & 0.450000 & -3.176100 & 3.325700 \\ \mathrm{H} & 0.200000 & -1.475200 & 3.639600 \\ \mathrm{C} & -0.476700 & 2.182300 & 2.854900 \\ \mathrm{H} & -0.450200 & 3.176200 & 3.325600 \\ \mathrm{H} & -0.200100 & 1.475400 & 3.639500 \\ \mathrm{C} & -3.382700 & 0.542700 & 1.027600\end{array}$




\begin{tabular}{|c|c|c|c|}
\hline & -4.218600 & 0.822400 & 1.685000 \\
\hline & -3.575900 & -0.485000 & 0.699900 \\
\hline & -3.308600 & 3.060800 & -2.419000 \\
\hline & -3.236700 & 3.688600 & -3.300900 \\
\hline & 3.143200 & 3.234100 & -2.406800 \\
\hline & 3.802100 & 3.146900 & -3.264300 \\
\hline & -3.370500 & 1.453800 & -0.183400 \\
\hline & 1.474000 & 3.332600 & -0.215000 \\
\hline & -1.474000 & -3.332500 & -0.214900 \\
\hline & 3.308600 & -3.061300 & -2.41 \\
\hline H & 3.236700 & -3.689100 & -3.30 \\
\hline & -3.143200 & -3.233900 & -2.406800 \\
\hline H & -3.802100 & -3.146600 & -3.264300 \\
\hline 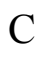 & 3.382700 & -0.542600 & 1.027800 \\
\hline ח & 4.218500 & -0.822300 & 1.68 \\
\hline H & 3.576000 & 0.485000 & 0.700000 \\
\hline & & 3.362200 & \\
\hline $\mathrm{H}$ & 0.813200 & 4.214500 & 1.626500 \\
\hline H & -0.479500 & 3.542500 & 0.642000 \\
\hline $\mathrm{C}$ & -0.545900 & -3.36 & 0.98 \\
\hline $\mathrm{H}$ & -0.813300 & -4.214400 & 1.62 \\
\hline $\mathrm{H}$ & 0.479 & -3.5 & 0.6 \\
\hline C & 1.905100 & -1.910700 & 2.38 \\
\hline $\mathrm{H}$ & 2.580700 & -2.048000 & 3.24 \\
\hline $\mathrm{H}$ & 2.203100 & -2.651200 & 1.643400 \\
\hline $\mathrm{C}$ & & -2.965200 & \\
\hline $\mathrm{H}$ & 5.379100 & -3.518000 & -1.989600 \\
\hline $\mathrm{C}$ & 2.155700 & 4.486600 & -0.608700 \\
\hline $\mathrm{H}$ & 2.039400 & 5.406100 & -0.0 \\
\hline $\mathrm{C}$ & -1.905200 & 1.910800 & 2.388500 \\
\hline $\mathrm{H}$ & -2.580800 & 2.048200 & 3.245900 \\
\hline $\mathrm{H}$ & -2.203200 & 2.651300 & 1.643200 \\
\hline $\mathrm{C}$ & -4.519500 & 2.156300 & -0.551300 \\
\hline $\mathrm{H}$ & -5.421500 & 2.075200 & 0.047400 \\
\hline $\mathrm{C}$ & 4.519600 & -2.156400 & -0.551000 \\
\hline $\mathrm{H}$ & 5.421500 & -2.075200 & 0.047700 \\
\hline $\mathrm{C}$ & -4.494300 & 2.965000 & -1.688600 \\
\hline $\mathrm{H}$ & -5.379100 & 3.517700 & -1.990100 \\
\hline $\mathrm{C}$ & -2.155800 & -4.486500 & -0.608600 \\
\hline $\mathrm{H}$ & -2.039500 & -5.406000 & -0.043200 \\
\hline $\mathrm{C}$ & -2.436100 & -2.128000 & -1.948500 \\
\hline $\mathrm{H}$ & -2.559100 & -1.159800 & -2.429800 \\
\hline $\mathrm{C}$ & 2.436100 & 2.128200 & -1.948600 \\
\hline $\mathrm{H}$ & 2.559100 & 1.160100 & -2.429800 \\
\hline $\mathrm{C}$ & -2.205700 & 2.332600 & -1.985700 \\
\hline
\end{tabular}




$\begin{array}{lrrr}\mathrm{H} & -1.264900 & 2.385900 & -2.525000 \\ \mathrm{C} & 2.990900 & 4.443900 & -1.725500 \\ \mathrm{H} & 3.526300 & 5.332600 & -2.045900 \\ \mathrm{C} & -2.991000 & -4.443700 & -1.725500 \\ \mathrm{H} & -3.526400 & -5.332400 & -2.046000 \\ \mathrm{C} & 2.205600 & -2.333000 & -1.985300 \\ \mathrm{H} & 1.264800 & -2.386400 & -2.524600 \\ \mathrm{Ac} & 0.000000 & 0.000000 & -0.071800\end{array}$

Zero-point correction $=$

Thermal correction to Energy=

Thermal correction to Enthalpy=

Thermal correction to Gibbs Free Energy=

Sum of electronic and zero-point Energies=

Sum of electronic and thermal Energies=

Sum of electronic and thermal Enthalpies=

Sum of electronic and thermal Free Energies=
0.720717 (Hartree/Particle)

0.759393

0.760337

0.651308

$-2132.305839$

$-2132.267162$

$-2132.266218$

$-2132.375247$

$\mathrm{E}(\mathrm{SCF})$ in SMD Solvation Model $=-2133.52670781$

Table S17. DFT-optimized Cartesian coordinates and energies for $\left[\mathrm{Ac}\left(\mathrm{L}^{\mathrm{pyd}}\right)\left(\mathrm{OH}_{2}\right)\right]^{3+}$

$\begin{array}{rrrr}\mathrm{O} & -0.130400 & -0.453500 & -2.642900 \\ \mathrm{H} & 0.386800 & -1.272500 & -2.841900 \\ \mathrm{H} & -1.058200 & -0.616800 & -2.928300 \\ \mathrm{~N} & 1.571600 & -1.374000 & 1.922100 \\ \mathrm{~N} & -1.758000 & 1.511700 & 1.726000 \\ \mathrm{~N} & -1.555400 & -1.598800 & 1.824000 \\ \mathrm{~N} & 2.290200 & 1.351400 & -0.724200 \\ \mathrm{~N} & -2.260800 & -1.568300 & -0.914800 \\ \mathrm{~N} & 1.343200 & 1.740700 & 1.848700 \\ \mathrm{~N} & 1.627400 & -2.183700 & -0.811800 \\ \mathrm{~N} & -1.355300 & 2.247200 & -0.917300 \\ \mathrm{C} & 0.391000 & 2.267100 & 2.869800 \\ \mathrm{H} & 0.814000 & 3.153000 & 3.366800 \\ \mathrm{H} & 0.283800 & 1.515300 & 3.653800 \\ \mathrm{C} & -0.669800 & -2.053100 & 2.936600 \\ \mathrm{H} & -1.127500 & -2.902000 & 3.466000 \\ \mathrm{H} & -0.606600 & -1.249300 & 3.671200 \\ \mathrm{C} & -0.981900 & 2.647200 & 2.315000 \\ \mathrm{H} & -1.559400 & 3.119200 & 3.124700 \\ \mathrm{H} & -0.867000 & 3.405800 & 1.536700 \\ \mathrm{C} & -2.825100 & -2.508100 & -0.149800 \\ \mathrm{C} & 0.732800 & -2.473300 & 2.493400 \\ \mathrm{H} & 0.664300 & -3.258800 & 1.734300\end{array}$




\begin{tabular}{|c|c|c|c|}
\hline $\mathrm{H}$ & 1.242000 & -2.923600 & 3.359400 \\
\hline c & -2.289300 & 0.637700 & 2.810100 \\
\hline & -3.170700 & 1.100300 & 3.279700 \\
\hline & -1.535000 & 0.577400 & 3.596200 \\
\hline & 1.997200 & -0.432600 & 3.003900 \\
\hline & 2.831100 & -0.865800 & 3.575700 \\
\hline & 1.174600 & -0.335300 & 3.713400 \\
\hline & 1.966800 & 2.885300 & 1.127800 \\
\hline $\mathrm{H}$ & 2.645400 & 3.439300 & 1.794200 \\
\hline H & 1.176600 & 3.588600 & 0.841700 \\
\hline 0 & 2.710300 & 2.472200 & -0.126600 \\
\hline$C$ & 2.573100 & -2.678900 & -0.006600 \\
\hline$C$ & -2.455200 & 2.746400 & -0.339300 \\
\hline C & -2.144500 & -2.799700 & 1.171000 \\
\hline $\mathrm{H}$ & -2.853300 & -3.296800 & 1.849900 \\
\hline $\mathrm{H}$ & -1.342500 & -3.522300 & 0.981400 \\
\hline$U$ & 2.790800 & -1.982400 & 1.321900 \\
\hline $\mathrm{H}$ & 3.255400 & -2.684200 & 400 \\
\hline $\mathrm{H}$ & 3.525200 & -1.186800 & 1.153400 \\
\hline $\mathrm{C}$ & -2.895200 & 2.075100 & 0.946300 \\
\hline $\mathrm{H}$ & -3.470500 & 2.787500 & 1.557100 \\
\hline $\mathrm{H}$ & -3.583800 & 1.260600 & 0.69 \\
\hline $\mathrm{C}$ & -2.680500 & -0.767300 & 2.354500 \\
\hline $\mathrm{H}$ & -3.160300 & -1.279400 & 3.202700 \\
\hline $\mathrm{H}$ & -3.436600 & -0.703200 & 1.566900 \\
\hline $\mathrm{C}$ & -4.457500 & -2.944300 & -1.837000 \\
\hline $\mathrm{H}$ & -5.324800 & -3.459600 & -2.237700 \\
\hline $\mathrm{C}$ & 3.393900 & -3.748000 & -0.411500 \\
\hline $\mathrm{H}$ & 4.150100 & -4.149700 & 0.256600 \\
\hline $\mathrm{C}$ & 2.426100 & 0.949900 & 2.510500 \\
\hline $\mathrm{H}$ & 2.830600 & 1.506800 & 3.369400 \\
\hline $\mathrm{H}$ & 3.246400 & 0.850800 & 1.794900 \\
\hline $\mathrm{C}$ & 3.761500 & 3.232300 & -0.664800 \\
\hline $\mathrm{H}$ & 4.105400 & 4.136700 & -0.171400 \\
\hline $\mathrm{C}$ & -3.950400 & -3.232500 & -0.583700 \\
\hline $\mathrm{H}$ & -4.399100 & -3.991800 & 0.050000 \\
\hline $\mathrm{C}$ & 4.335800 & 2.783300 & -1.840600 \\
\hline $\mathrm{H}$ & 5.149300 & 3.319400 & -2.319200 \\
\hline $\mathrm{C}$ & -3.159100 & 3.814200 & -0.918500 \\
\hline $\mathrm{H}$ & -4.047700 & 4.219200 & -0.443300 \\
\hline $\mathrm{C}$ & 3.208300 & -4.259300 & -1.681800 \\
\hline $\mathrm{H}$ & 3.804800 & -5.082700 & -2.061900 \\
\hline $\mathrm{C}$ & -2.673800 & 4.327700 & -2.108800 \\
\hline $\mathrm{H}$ & -3.165500 & 5.151400 & -2.617100 \\
\hline & -1.503500 & 3.757700 & -2.639900 \\
\hline
\end{tabular}




$\begin{array}{lrrr}\mathrm{H} & -1.058800 & 4.119300 & -3.562000 \\ \mathrm{C} & -3.801600 & -1.955500 & -2.590500 \\ \mathrm{H} & -4.129700 & -1.684000 & -3.589400 \\ \mathrm{C} & 3.840800 & 1.591300 & -2.398700 \\ \mathrm{H} & 4.251800 & 1.176400 & -3.313800 \\ \mathrm{C} & 2.213400 & -3.668900 & -2.479800 \\ \mathrm{H} & 2.018800 & -4.002600 & -3.494500 \\ \mathrm{~N} & 2.850300 & 0.893900 & -1.849700 \\ \mathrm{~N} & -0.862700 & 2.748300 & -2.055800 \\ \mathrm{~N} & -2.738200 & -1.297200 & -2.137800 \\ \mathrm{~N} & 1.450800 & -2.669900 & -2.048000 \\ \mathrm{Ac} & 0.000400 & 0.010700 & -0.112600\end{array}$

Zero-point correction $=$

Thermal correction to Energy=
0.672283 (Hartree/Particle)

0.709433

0.710377

Thermal correction to Gibbs Free Energy $=\quad 0.604673$

Sum of electronic and zero-point Energies $=\quad-2196.397044$

Sum of electronic and thermal Energies $=\quad-2196.359894$

Sum of electronic and thermal Enthalpies $=\quad-2196.358950$

Sum of electronic and thermal Free Energies $=\quad-2196.464653$

$\mathrm{E}(\mathrm{SCF})$ in SMD Solvation Model $=-2197.56971250$

Table S18. DFT-optimized Cartesian coordinates and energies for $\left[\mathrm{Ac}\left(\mathrm{L}^{\mathrm{pyr}}\right)\left(\mathrm{OH}_{2}\right)\right]^{3+}$

$\begin{array}{rrrr}\mathrm{O} & -0.000000 & 0.000200 & -2.855300 \\ \mathrm{H} & -0.612200 & -0.467900 & -3.450400 \\ \mathrm{H} & 0.612300 & 0.468200 & -3.450300 \\ \mathrm{~N} & -0.675400 & -2.072900 & 1.784600 \\ \mathrm{~N} & 0.675500 & 2.072800 & 1.784700 \\ \mathrm{~N} & -2.075700 & 0.676200 & 1.795300 \\ \mathrm{~N} & 2.154100 & -1.616400 & -0.891800 \\ \mathrm{~N} & -2.154200 & 1.616500 & -0.891700 \\ \mathrm{~N} & 2.075800 & -0.676300 & 1.795200 \\ \mathrm{~N} & -1.689400 & -2.099400 & -0.871000 \\ \mathrm{~N} & 1.689500 & 2.099400 & -0.871000 \\ \mathrm{C} & 2.187200 & 0.350400 & 2.877100 \\ \mathrm{H} & 3.163000 & 0.269800 & 3.378100 \\ \mathrm{H} & 1.442500 & 0.119200 & 3.640900 \\ \mathrm{C} & -2.187100 & -0.350600 & 2.877200 \\ \mathrm{H} & -3.162800 & -0.270000 & 3.378200 \\ \mathrm{H} & -1.442300 & -0.119400 & 3.640900 \\ \mathrm{C} & 2.014100 & 1.790700 & 2.395800 \\ \mathrm{H} & 2.189500 & 2.464000 & 3.247600\end{array}$




$\begin{array}{lrrr}\mathrm{H} & 2.778800 & 2.030800 & 1.653700 \\ \mathrm{C} & -3.309000 & 1.614200 & -0.180100 \\ \mathrm{C} & -2.014100 & -1.790800 & 2.395800 \\ \mathrm{H} & -2.778700 & -2.030900 & 1.653700 \\ \mathrm{H} & -2.189400 & -2.464100 & 3.247600 \\ \mathrm{C} & -0.351900 & 2.203400 & 2.865100 \\ \mathrm{H} & -0.270600 & 3.188200 & 3.347800 \\ \mathrm{H} & -0.118100 & 1.473200 & 3.641800 \\ \mathrm{C} & 0.352100 & -2.203600 & 2.865000 \\ \mathrm{H} & 0.270700 & -3.188400 & 3.347600 \\ \mathrm{H} & 0.118200 & -1.473400 & 3.641700 \\ \mathrm{C} & 3.369800 & -0.746800 & 1.059000 \\ \mathrm{H} & 4.169900 & -1.108800 & 1.720600 \\ \mathrm{H} & 3.653000 & 0.268100 & 0.757500 \\ \mathrm{C} & 3.309000 & -1.614200 & -0.180400 \\ \mathrm{C} & -1.634700 & -3.277700 & -0.201600 \\ \mathrm{C} & 1.634700 & 3.277700 & -0.201500 \\ \mathrm{C} & -3.369700 & 0.746800 & 1.059100 \\ \mathrm{H} & -4.169800 & 1.108700 & 1.720800 \\ \mathrm{H} & -3.653000 & -0.268100 & 0.757600 \\ \mathrm{C} & -0.749400 & -3.353800 & 1.025700 \\ \mathrm{H} & -1.099700 & -4.168400 & 1.676000 \\ \mathrm{H} & 0.263600 & -3.627100 & 0.707600 \\ \mathrm{C} & 0.749500 & 3.353700 & 1.025800 \\ \mathrm{H} & 2.325400 & 5.330600 & -0.119500 \\ \mathrm{H} & 1.099800 & 4.168300 & 1.676200 \\ \mathrm{H} & -0.263500 & 3.627000 & 0.707800 \\ \mathrm{C} & -1.792500 & 2.020100 & 2.392000 \\ \mathrm{H} & -2.461900 & 2.204500 & 3.245200 \\ \mathrm{H} & -2.038300 & 2.775600 & 1.642000 \\ \mathrm{C} & -4.270400 & 3.102600 & -1.778100 \\ \mathrm{H} & -5.089700 & 3.702800 & -2.166800 \\ \mathrm{C} & -2.354200 & -4.383500 & -0.649000 \\ \mathrm{H} & -2.325400 & -5.330600 & -0.119600 \\ \mathrm{C} & 1.792600 & -2.020200 & 2.391800 \\ \mathrm{H} & 2.462100 & -2.204600 & 3.245000 \\ \mathrm{H} & 2.038400 & -2.775700 & 1.641700 \\ \mathrm{H} & 4.407200 & -2.359200 & -0.601800 \\ \mathrm{H} & -4.335500 & -2.369200 & -0.039600 \\ \mathrm{H} & -5.335500 & 2.369300 & -0.039200 \\ \mathrm{H} & 2.354200 & -3.102500 & -1.778500 \\ \mathrm{H} & 2.060000 & -1.953700\end{array}$




$\begin{array}{lrrr}\mathrm{H} & 2.587900 & 1.098800 & -2.457200 \\ \mathrm{C} & -2.495600 & -2.059900 & -1.953700 \\ \mathrm{H} & -2.587900 & -1.098700 & -2.457200 \\ \mathrm{C} & 2.132000 & -2.386600 & -2.001700 \\ \mathrm{H} & 1.202000 & -2.402000 & -2.563000 \\ \mathrm{C} & -3.121800 & -4.231000 & -1.807600 \\ \mathrm{H} & -3.695700 & -5.057400 & -2.220100 \\ \mathrm{C} & 3.121800 & 4.231100 & -1.807500 \\ \mathrm{H} & 3.695600 & 5.057600 & -2.219900 \\ \mathrm{C} & -2.132200 & 2.386700 & -2.001500 \\ \mathrm{H} & -1.202100 & 2.402000 & -2.562800 \\ \mathrm{~N} & 3.202800 & 3.059200 & -2.454900 \\ \mathrm{~N} & -3.125400 & 3.123200 & -2.474800 \\ \mathrm{~N} & -3.202800 & -3.059100 & -2.455000 \\ \mathrm{~N} & 3.125300 & -3.123100 & -2.475100 \\ \mathrm{Ac} & -0.000000 & 0.000000 & -0.069200\end{array}$

Zero-point correction $=$

Thermal correction to Energy=
0.672662 (Hartree/Particle)

0.711035

0.711979

0.602950

$-2196.459830$

$-2196.421457$

$-2196.420512$

$-2196.529542$

$\mathrm{E}(\mathrm{SCF})$ in SMD Solvation Model $=-2197.69415301$

Table S19. DFT-optimized Cartesian coordinates and energies for $\left[\mathrm{Ac}\left(\mathrm{L}^{\mathrm{pz}}\right)\left(\mathrm{OH}_{2}\right)\right]^{3+}$

$\begin{array}{rrrr}\mathrm{O} & 0.000000 & 0.000200 & -2.842800 \\ \mathrm{H} & -0.587000 & -0.502000 & -3.434700 \\ \mathrm{H} & 0.586900 & 0.502500 & -3.434600 \\ \mathrm{~N} & -0.717700 & -2.051100 & 1.763600 \\ \mathrm{~N} & 0.717800 & 2.051000 & 1.763700 \\ \mathrm{~N} & -2.054900 & 0.718300 & 1.777500 \\ \mathrm{~N} & 2.136200 & -1.678600 & -0.930500 \\ \mathrm{~N} & -2.136300 & 1.678600 & -0.930400 \\ \mathrm{~N} & 2.054900 & -0.718400 & 1.777400 \\ \mathrm{~N} & -1.760100 & -2.065100 & -0.913100 \\ \mathrm{~N} & 1.760100 & 2.065100 & -0.913000 \\ \mathrm{C} & 2.190500 & 0.304300 & 2.861500 \\ \mathrm{H} & 3.164600 & 0.199600 & 3.361000 \\ \mathrm{H} & 1.440700 & 0.088800 & 3.625000 \\ \mathrm{C} & -2.190300 & -0.304500 & 2.861600\end{array}$




\begin{tabular}{|c|c|c|c|}
\hline $\mathrm{H}$ & -3.164400 & -0.199800 & 3.361100 \\
\hline & -1.440500 & -0.089000 & 3.625000 \\
\hline & 2.049400 & 1.747900 & 2.380800 \\
\hline & 2.232000 & 2.418000 & 3.233300 \\
\hline & 2.822000 & 1.974500 & 1.643200 \\
\hline & -3.266500 & 1.694700 & -0.190000 \\
\hline 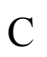 & -2.049300 & -1.748000 & 2.380800 \\
\hline 1 & -2.822000 & -1.974600 & 1.643200 \\
\hline $\mathrm{H}$ & -2.231800 & -2.418200 & 3.233200 \\
\hline & -0.305800 & 2.212500 & 2.845100 \\
\hline 7 & -0.200500 & 3.199000 & 3.319300 \\
\hline H & -0.086200 & 1.482800 & 3.626400 \\
\hline $\mathcal{C}$ & 0.305900 & -2.212700 & 2.844900 \\
\hline H & 0.200700 & -3.199200 & 3.31 \\
\hline$H$ & 0.086400 & -1.483000 & 3.626300 \\
\hline$C$ & 3.344100 & -0.807800 & 1.03 \\
\hline $\mathrm{H}$ & 4.145000 & -1.168300 & 1.693600 \\
\hline $\mathrm{H}$ & 3.632500 & 0.203000 & 0.722000 \\
\hline $\mathrm{C}$ & 3.266500 & -1.694700 & -0.190300 \\
\hline $\mathrm{C}$ & -1.723400 & -3.222500 & -0.217900 \\
\hline $\mathrm{C}$ & 1.723500 & 3.222500 & -0.217800 \\
\hline $\mathrm{C}$ & -3.344100 & 0.807700 & 1.032100 \\
\hline $\mathrm{H}$ & -4.144900 & 1.168200 & 3900 \\
\hline $\mathrm{H}$ & -3.632500 & -0.203000 & 0.722200 \\
\hline $\mathrm{C}$ & -0.812700 & -3.322100 & 7300 \\
\hline $\mathrm{H}$ & -1.158400 & -4.142100 & 1.633500 \\
\hline $\mathrm{H}$ & 0.195300 & -3.597600 & 0.65 \\
\hline $\mathrm{C}$ & 0.812700 & 3.322100 & 0.987500 \\
\hline $\mathrm{H}$ & 1.158500 & 4.142000 & 1.633700 \\
\hline $\mathrm{H}$ & -0.195200 & 3.597600 & 0.655600 \\
\hline $\mathrm{C}$ & -1.750200 & 2.057200 & 2.375400 \\
\hline $\mathrm{H}$ & -2.414800 & 2.251000 & 3.230000 \\
\hline $\mathrm{H}$ & -1.984900 & 2.817900 & 1.627500 \\
\hline $\mathrm{C}$ & -2.509600 & -4.313400 & -0.620600 \\
\hline $\mathrm{H}$ & -2.492900 & -5.247800 & -0.062900 \\
\hline $\mathrm{C}$ & 1.750300 & -2.057300 & 2.375200 \\
\hline $\mathrm{H}$ & 2.415000 & -2.251200 & 3.229800 \\
\hline $\mathrm{H}$ & 1.985000 & -2.818000 & 1.627200 \\
\hline $\mathrm{C}$ & 4.351300 & -2.498000 & -0.570500 \\
\hline $\mathrm{H}$ & 5.262100 & -2.522400 & 0.024400 \\
\hline $\mathrm{C}$ & -4.351400 & 2.498000 & -0.570100 \\
\hline $\mathrm{H}$ & -5.262200 & 2.522400 & 0.024900 \\
\hline $\mathrm{C}$ & 2.509600 & 4.313500 & -0.620400 \\
\hline $\mathrm{H}$ & 2.493000 & 5.247800 & -0.062700 \\
\hline & 3.358200 & 3.113300 & -2.360700 \\
\hline
\end{tabular}




$\begin{array}{lrrr}\mathrm{H} & 4.023900 & 3.063400 & -3.218700 \\ \mathrm{C} & -3.205400 & 3.253900 & -2.386600 \\ \mathrm{H} & -3.175400 & 3.885400 & -3.271000 \\ \mathrm{C} & 3.205200 & -3.253800 & -2.387000 \\ \mathrm{H} & 3.175100 & -3.885200 & -3.271400 \\ \mathrm{C} & -3.358100 & -3.113200 & -2.360800 \\ \mathrm{H} & -4.023900 & -3.063300 & -3.218800 \\ \mathrm{C} & -2.110600 & 2.466400 & -2.023900 \\ \mathrm{H} & -1.201500 & 2.467400 & -2.616800 \\ \mathrm{C} & 2.591400 & 2.012900 & -1.973700 \\ \mathrm{H} & 2.665400 & 1.067700 & -2.506500 \\ \mathrm{C} & 2.110400 & -2.466400 & -2.024100 \\ \mathrm{H} & 1.201200 & -2.467300 & -2.616900 \\ \mathrm{C} & -2.591400 & -2.012800 & -1.973800 \\ \mathrm{H} & -2.665500 & -1.067600 & -2.506600 \\ \mathrm{~N} & 4.325800 & -3.265400 & -1.660800 \\ \mathrm{~N} & 3.309000 & 4.265400 & -1.685900 \\ \mathrm{~N} & -4.326000 & 3.265500 & -1.660400 \\ \mathrm{~N} & -3.309000 & -4.265300 & -1.686000 \\ \mathrm{Ac} & -0.000000 & 0.000000 & -0.071900\end{array}$

Zero-point correction $=$

Thermal correction to Energy=

Thermal correction to Enthalpy=
0.671706 (Hartree/Particle)

0.710027

0.710971

Thermal correction to Gibbs Free Energy $=\quad 0.602033$

Sum of electronic and zero-point Energies $=\quad-2196.412949$

Sum of electronic and thermal Energies $=\quad-2196.374628$

Sum of electronic and thermal Enthalpies $=\quad-2196.373684$

Sum of electronic and thermal Free Energies $=\quad-2196.482622$

$\mathrm{E}(\mathrm{SCF})$ in SMD Solvation Model $=-2197.65897545$

Table S20. DFT-optimized Cartesian coordinates and energies for $\left[\mathrm{Ac}(\mathrm{DOTA})\left(\mathrm{OH}_{2}\right)\right]^{1-}$

$\begin{array}{lrrr}\mathrm{N} & 0.852400 & 1.907900 & 1.411200 \\ \mathrm{~N} & -1.178100 & -1.914700 & 1.235200 \\ \mathrm{~N} & 1.744300 & -1.020300 & 1.510000 \\ \mathrm{~N} & -2.067600 & 1.018700 & 1.151200 \\ \mathrm{O} & 1.987400 & 1.567600 & -1.095700 \\ \mathrm{O} & 1.729600 & -1.851900 & -1.135300 \\ \mathrm{O} & -1.758900 & -1.605300 & -1.451700 \\ \mathrm{O} & -1.471400 & 1.888100 & -1.397800 \\ \mathrm{O} & -3.494700 & 2.896500 & -1.552200 \\ \mathrm{O} & 2.942500 & 3.615600 & -0.970900 \\ \mathrm{O} & -2.778500 & -3.628500 & -1.488100\end{array}$




$\begin{array}{lrrr}\mathrm{O} & 3.789000 & -2.762600 & -0.906800 \\ \mathrm{C} & 2.850400 & -2.069700 & -0.524000 \\ \mathrm{C} & 3.019800 & -1.304600 & 0.814900 \\ \mathrm{C} & 1.940000 & -0.040800 & 2.593500 \\ \mathrm{C} & 1.183700 & -2.286100 & 2.026100 \\ \mathrm{C} & -0.304500 & -2.223100 & 2.380800 \\ \mathrm{C} & 2.056000 & 1.405300 & 2.105000 \\ \mathrm{C} & 2.157200 & 2.751400 & -0.594600 \\ \mathrm{C} & 1.215400 & 3.089200 & 0.593500 \\ \mathrm{C} & -0.215800 & 2.227100 & 2.376100 \\ \mathrm{C} & -1.616600 & 2.286300 & 1.762300 \\ \mathrm{C} & -3.164800 & 1.301600 & 0.196000 \\ \mathrm{C} & -2.475400 & 0.043600 & 2.177000 \\ \mathrm{C} & -2.691200 & 2.127200 & -1.034400 \\ \mathrm{C} & -2.491400 & -1.406100 & 1.684100 \\ \mathrm{C} & -1.386000 & -3.107000 & 0.380000 \\ \mathrm{C} & -2.060500 & -2.772500 & -0.980500 \\ \mathrm{H} & 3.710600 & -1.866200 & 1.464100 \\ \mathrm{H} & 3.500700 & -0.353500 & 0.564300 \\ \mathrm{H} & 2.845900 & -0.281600 & 3.180300 \\ \mathrm{H} & 1.099900 & -0.124600 & 3.289200 \\ \mathrm{H} & 1.740900 & -2.624100 & 2.920000 \\ \mathrm{H} & 1.340300 & -3.047000 & 1.258300 \\ \mathrm{H} & -0.588900 & -3.187300 & 2.841300 \\ \mathrm{H} & -0.466500 & -1.463000 & 3.151600 \\ \mathrm{H} & 2.305600 & 2.047100 & 2.970600 \\ \mathrm{H} & 2.893600 & 1.486100 & 1.409500 \\ \mathrm{H} & 1.686000 & 3.871700 & 1.209900 \\ \mathrm{H} & 0.301300 & 3.506700 & 0.158400 \\ \mathrm{H} & -0.016300 & 3.194400 & 2.873700 \\ \mathrm{H} & -0.197800 & 1.472500 & 3.168400 \\ \mathrm{H} & -2.324600 & 2.618100 & 2.544500 \\ \mathrm{H} & -1.636700 & 3.050900 & 0.983600 \\ \mathrm{H} & -3.996000 & 1.831400 & 0.688100 \\ & -3.551100 & 0.351300 & -0.188100 \\ \mathrm{H} & -3.481100 & 0.283900 & 2.569300 \\ \mathrm{H} & -2.902100 & -2.043500 & 2.489100 \\ \mathrm{H} & -1.984300 & -3.871000 & 0.901800 \\ \mathrm{H} & -1.56900 & -3.546900 & 0.149200 \\ \mathrm{H} & 0.003700 & -0.742800 \\ \mathrm{H} & -0.864300 & -2.863800 \\ \mathrm{H} & -0.053700 & -3.184500\end{array}$


Zero-point correction $=$

Thermal correction to Energy=

Thermal correction to Enthalpy=

Thermal correction to Gibbs Free Energy=

Sum of electronic and zero-point Energies $=$

Sum of electronic and thermal Energies=

Sum of electronic and thermal Enthalpies=

Sum of electronic and thermal Free Energies=
0.450361 (Hartree/Particle)

0.480247

0.481191

0.390962

$-1897.021615$

$-1896.991729$

$-1896.990785$

$-1897.081014$

$\mathrm{E}(\mathrm{SCF})$ in SMD Solvation Model $=-1897.65258373$

Table S21. DFT-optimized Cartesian coordinates and energies for $\left[\mathrm{Ac}(\mathrm{CHX}-\mathrm{DTPA})\left(\mathrm{OH}_{2}\right)\right]^{2-}$

$\begin{array}{lrrr}\text { Ac } & 0.841200 & -0.763800 & 0.128900 \\ \mathrm{O} & 3.326400 & -0.881500 & -0.271300 \\ \mathrm{O} & 5.442100 & -0.075500 & -0.297000 \\ \mathrm{O} & 0.422200 & 0.477900 & -2.075200 \\ \mathrm{O} & 0.625000 & 2.232000 & -3.485800 \\ \mathrm{O} & 1.216500 & 0.528800 & 2.271400 \\ \mathrm{O} & 0.646800 & 2.013900 & 3.880300 \\ \mathrm{O} & -0.143100 & -2.589900 & -1.388100 \\ \mathrm{O} & -1.568500 & -3.225500 & -3.022400 \\ \mathrm{O} & -0.727400 & -1.896200 & 1.917900 \\ \mathrm{O} & -2.711400 & -2.521500 & 2.812500 \\ \mathrm{~N} & 2.313700 & 1.691300 & -0.393900 \\ \mathrm{~N} & -0.691400 & 1.717400 & 0.550200 \\ \mathrm{~N} & -2.107000 & -0.891500 & -0.343900 \\ \mathrm{C} & 1.634200 & 2.806100 & 0.276000 \\ \mathrm{C} & 0.112500 & 2.870300 & 0.063600 \\ \mathrm{C} & -1.995000 & 1.677500 & -0.200400 \\ \mathrm{C} & -2.822900 & 0.374600 & -0.001800 \\ \mathrm{C} & -4.182500 & 0.487000 & -0.745100 \\ \mathrm{C} & -5.010900 & 1.710000 & -0.345800 \\ \mathrm{C} & -4.203200 & 2.977800 & -0.625400 \\ \mathrm{C} & -2.870300 & 2.920500 & 0.126600 \\ \mathrm{C} & 3.660800 & 1.457900 & 0.152900 \\ \mathrm{C} & 4.218800 & 0.046600 & -0.186500 \\ \mathrm{C} & 2.351600 & 1.862600 & -1.856000 \\ \mathrm{C} & 1.011800 & 1.518100 & -2.551400 \\ \mathrm{C} & -0.832500 & 1.766600 & 2.023600 \\ \mathrm{C} & 0.466600 & 1.419800 & 2.811800 \\ \mathrm{C} & -2.125200 & -1.263500 & -1.779100 \\ \mathrm{C} & -1.213400 & -2.480800 & -2.105700 \\ \mathrm{C} & -2.642400 & -1.996200 & 0.483000\end{array}$




$\begin{array}{rrrr}\mathrm{C} & -1.995200 & -2.134900 & 1.882900 \\ \mathrm{H} & 2.031500 & 3.777500 & -0.084600 \\ \mathrm{H} & 1.860600 & 2.749300 & 1.340700 \\ \mathrm{H} & -0.217400 & 3.799200 & 0.562400 \\ \mathrm{H} & -0.091300 & 2.998300 & -1.001800 \\ \mathrm{H} & -1.707200 & 1.716000 & -1.256800 \\ \mathrm{H} & -3.051700 & 0.292100 & 1.068400 \\ \mathrm{H} & -3.996500 & 0.540200 & -1.825200 \\ \mathrm{H} & -4.752900 & -0.433300 & -0.572800 \\ \mathrm{H} & -5.962700 & 1.718000 & -0.896800 \\ \mathrm{H} & -5.264800 & 1.663900 & 0.724100 \\ \mathrm{H} & -4.761700 & 3.878000 & -0.329500 \\ \mathrm{H} & -4.020500 & 3.060600 & -1.707100 \\ \mathrm{H} & -3.085100 & 2.930100 & 1.203800 \\ \mathrm{H} & -2.294400 & 3.828900 & -0.081500 \\ \mathrm{H} & 3.590600 & 1.510000 & 1.245700 \\ \mathrm{H} & 4.384400 & 2.220100 & -0.181000 \\ \mathrm{H} & 3.101300 & 1.168600 & -2.253300 \\ \mathrm{H} & 2.659700 & 2.885000 & -2.133900 \\ \mathrm{H} & -1.576200 & 1.023700 & 2.330800 \\ \mathrm{H} & -1.174700 & 2.752300 & 2.373100 \\ \mathrm{H} & -1.743000 & -0.421600 & -2.365300 \\ \mathrm{H} & -3.132200 & -1.522400 & -2.134800 \\ \mathrm{H} & -3.734200 & -1.935600 & 0.603400 \\ \mathrm{H} & -2.437000 & -2.937800 & -0.036700 \\ \mathrm{H} & 0.429700 & -3.310900 & 1.440600 \\ \mathrm{H} & 0.685200 & -3.668100 & -0.039200 \\ \mathrm{O} & 1.147900 & -3.568600 & 0.820900\end{array}$

Zero-point correction $=$

Thermal correction to Energy=

0.463724 (Hartree/Particle)

0.496543

Thermal correction to Enthalpy= 0.497487

Thermal correction to Gibbs Free Energy $=\quad 0.399984$

Sum of electronic and zero-point Energies $=\quad-2068.952630$

Sum of electronic and thermal Energies $=\quad-2068.919810$

Sum of electronic and thermal Enthalpies $=\quad-2068.918866$

Sum of electronic and thermal Free Energies $=\quad-2069.016370$

$\mathrm{E}(\mathrm{SCF})$ in SMD Solvation Model= -2069.73354452 


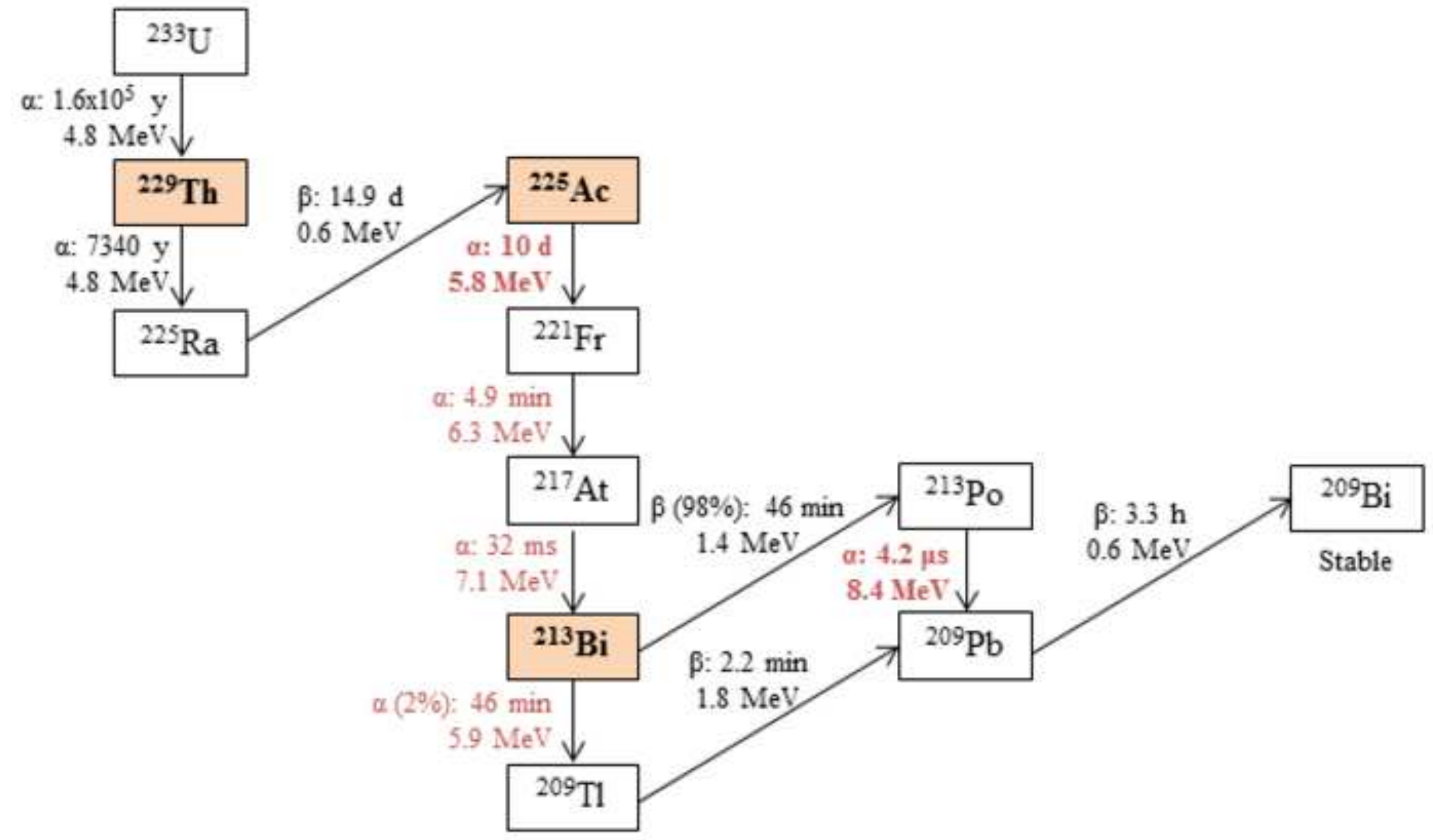



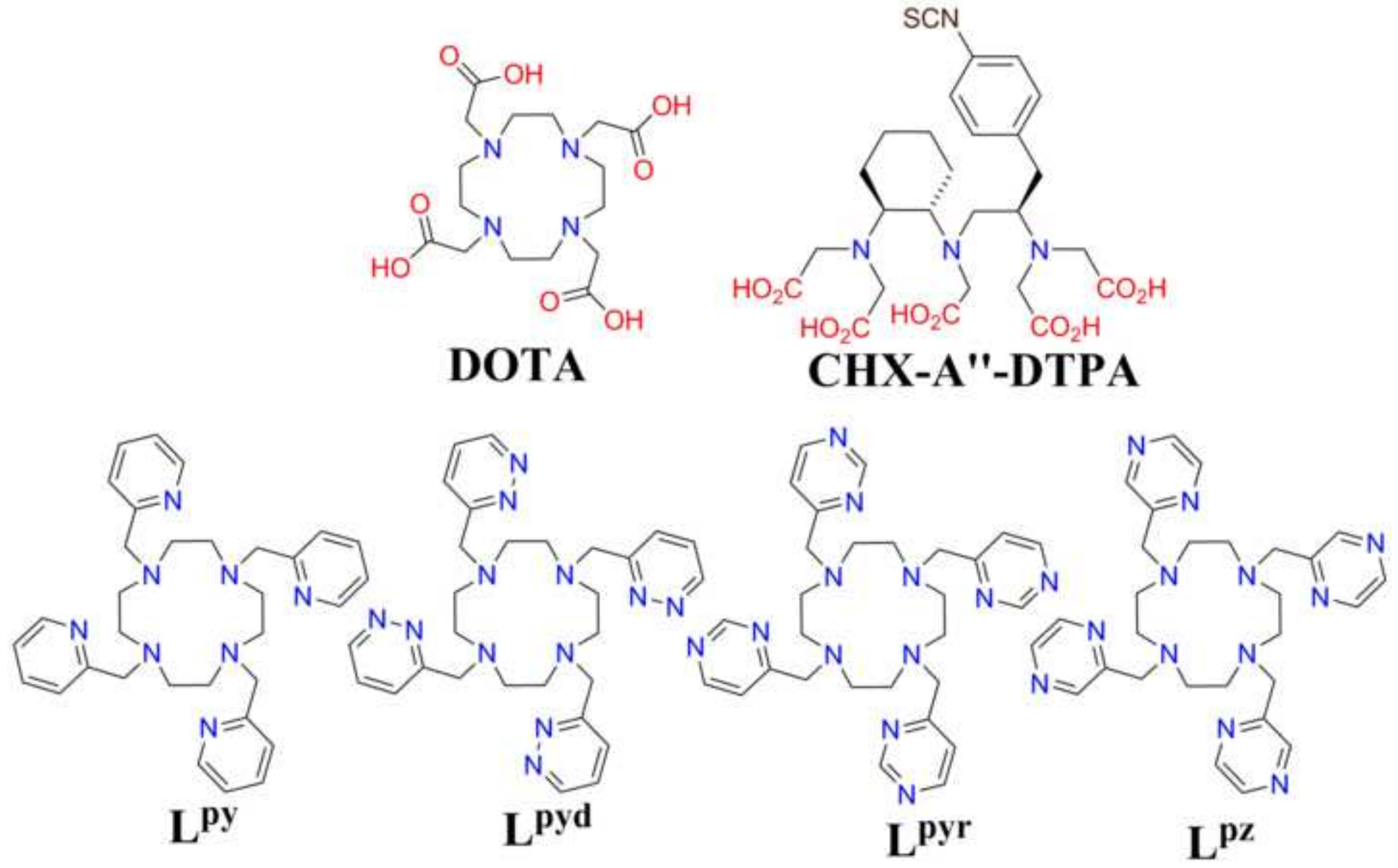


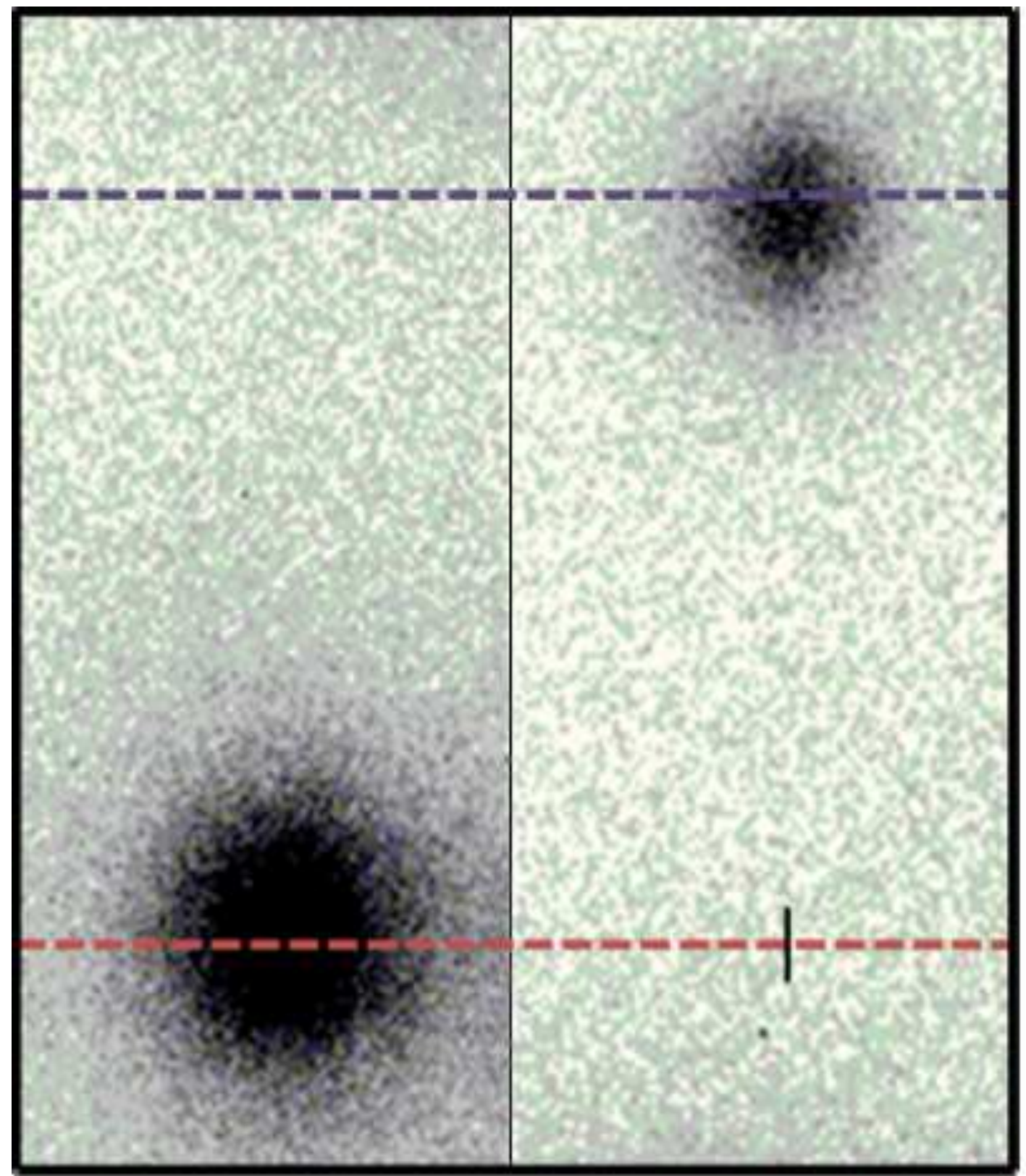

\author{
$R_{f}=0$ \\ Metal complex

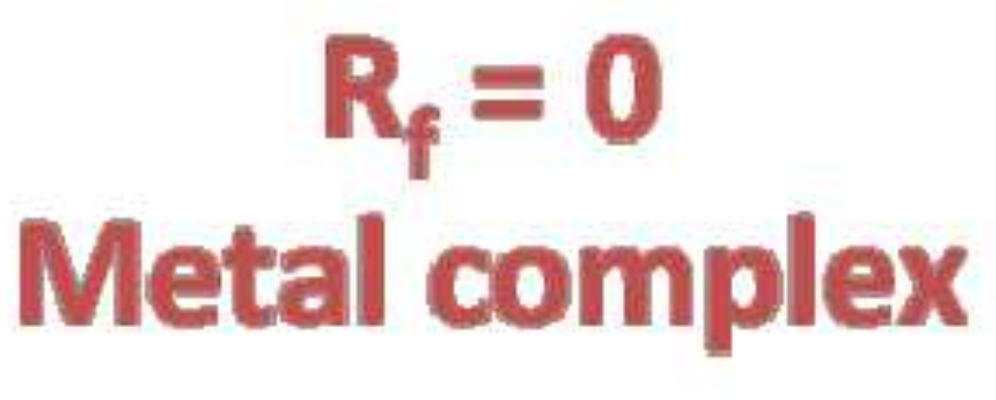




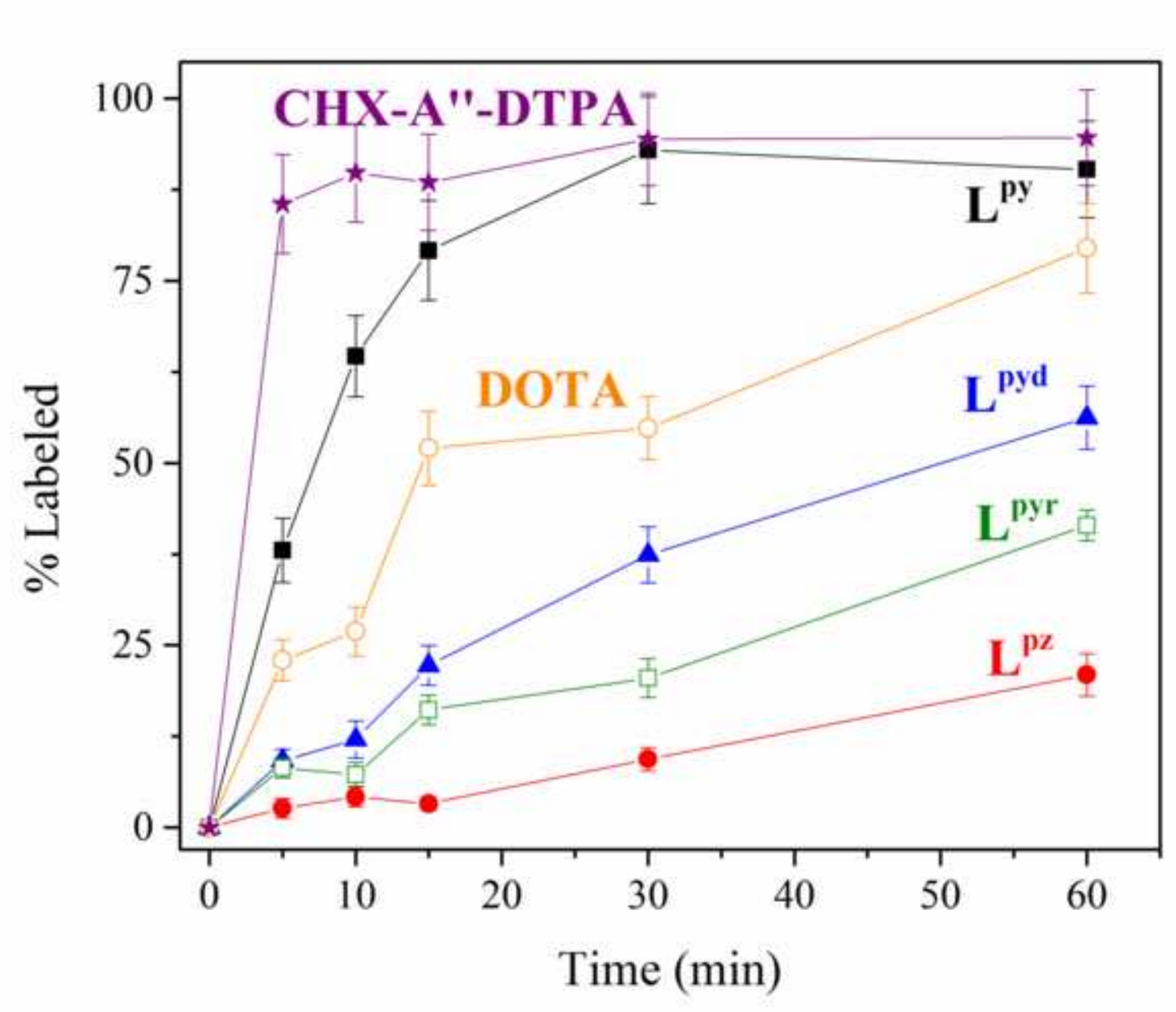




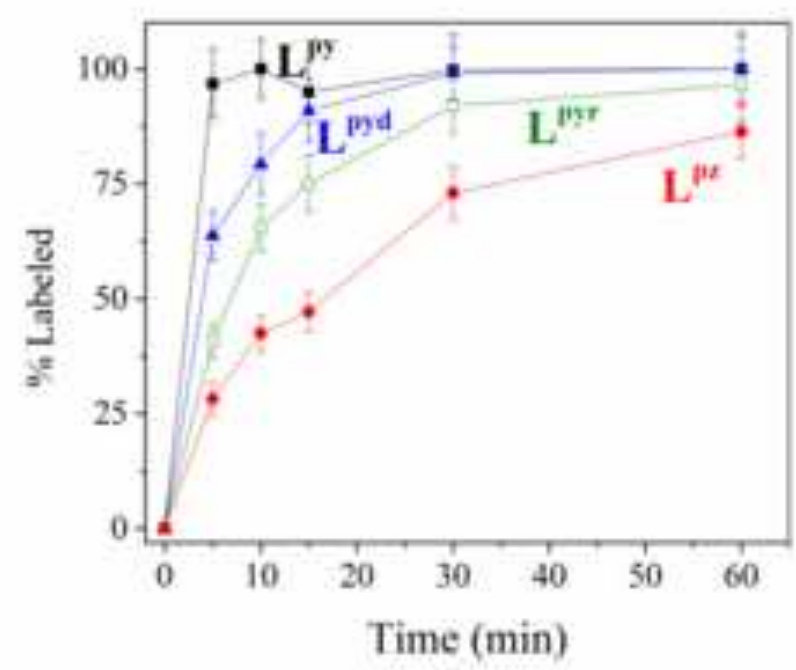

(a)

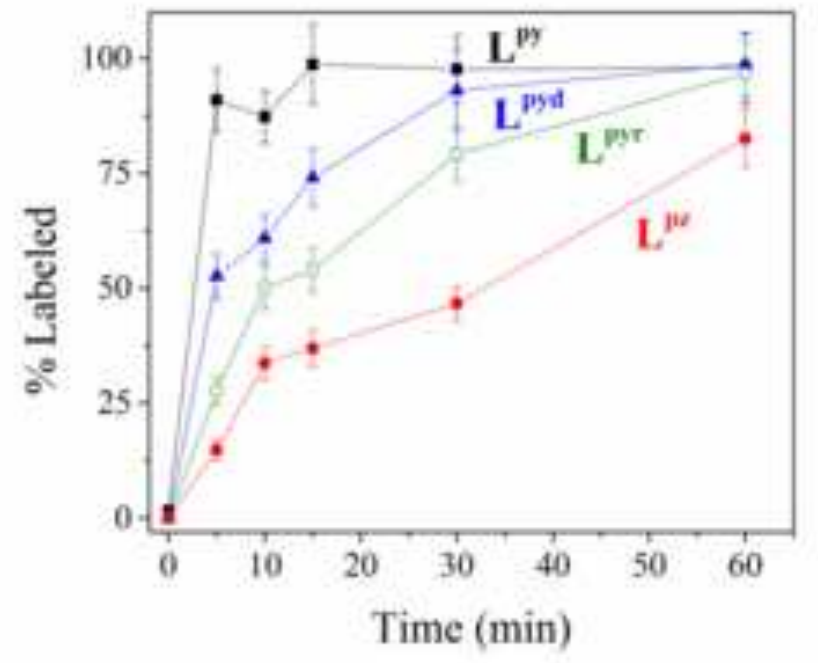

(b)

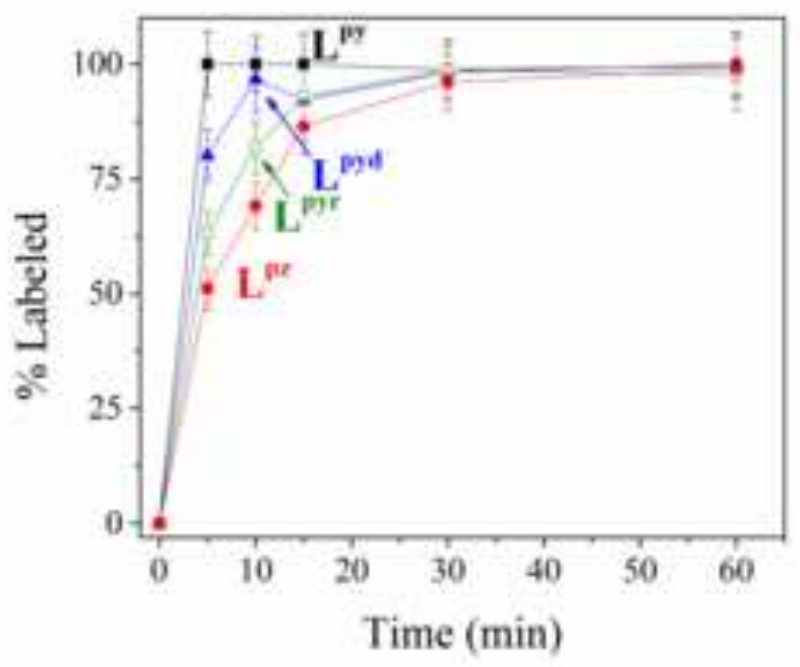

(c) 


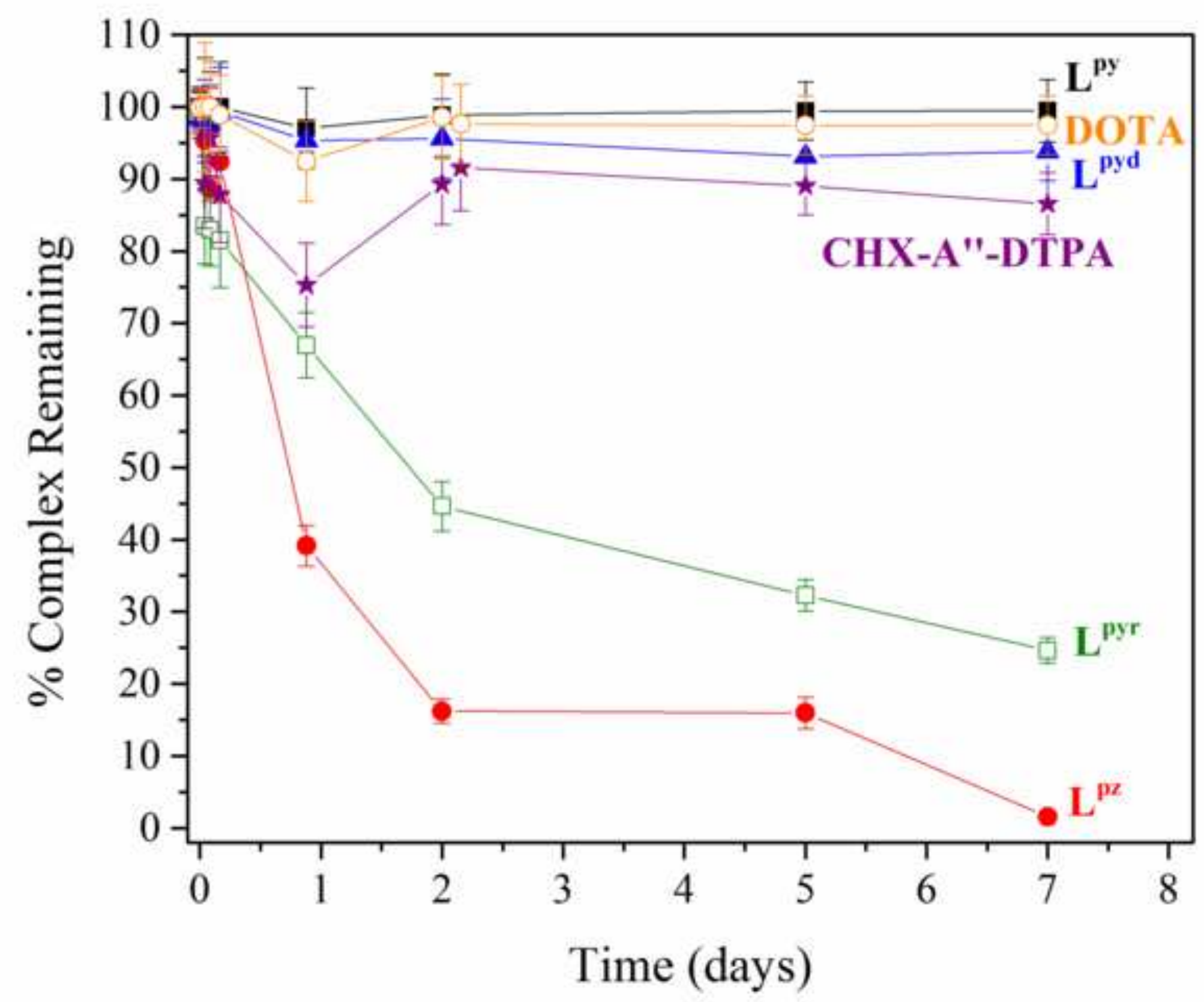




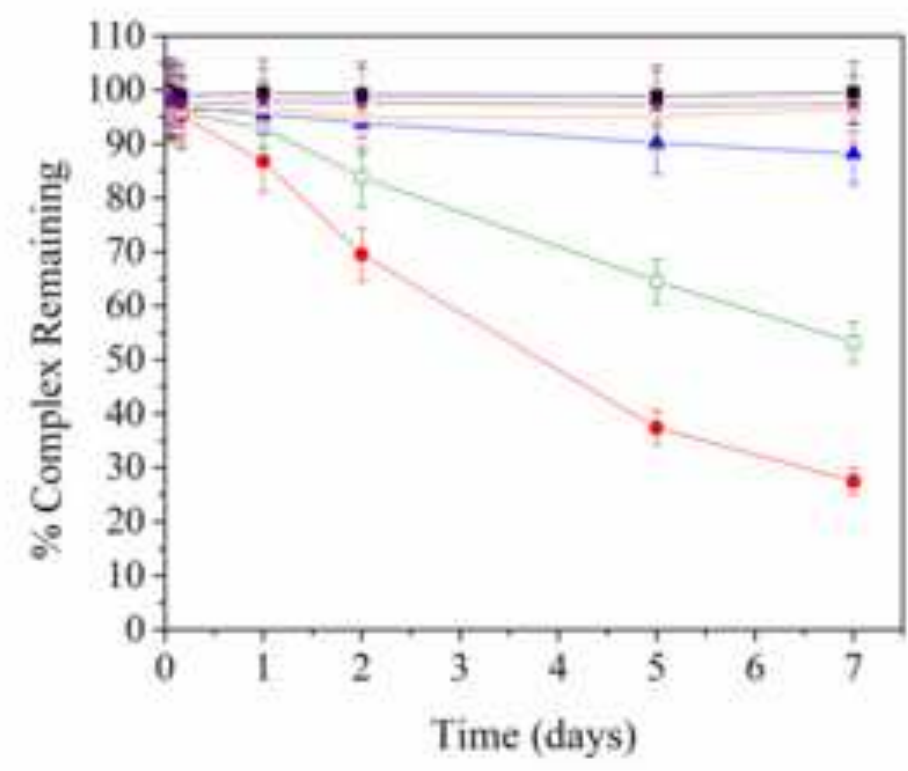

(a)

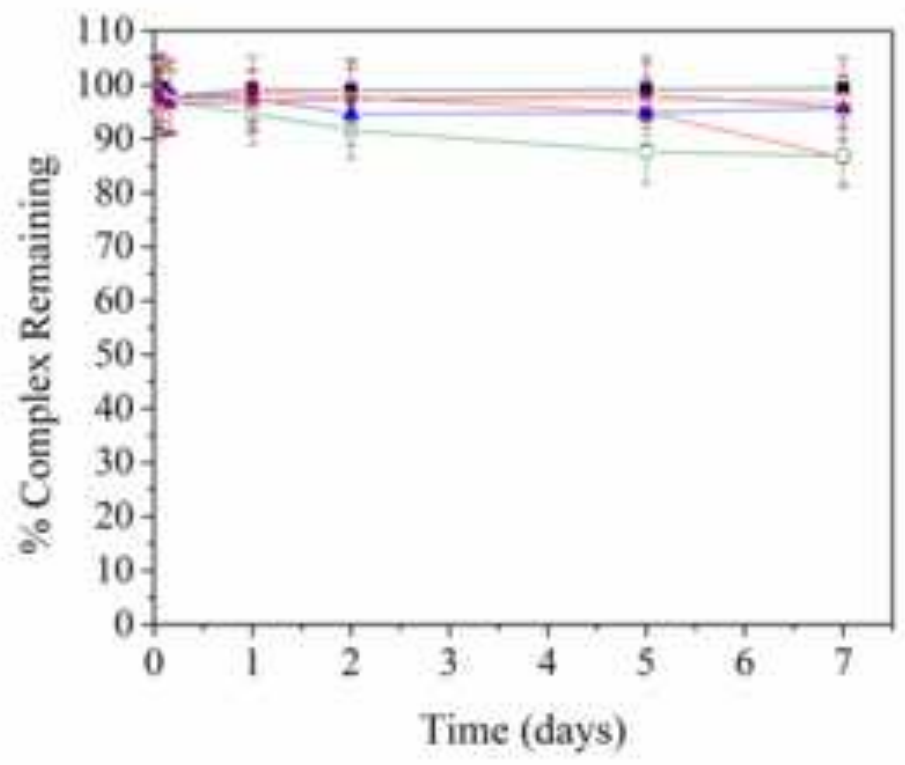

(c)

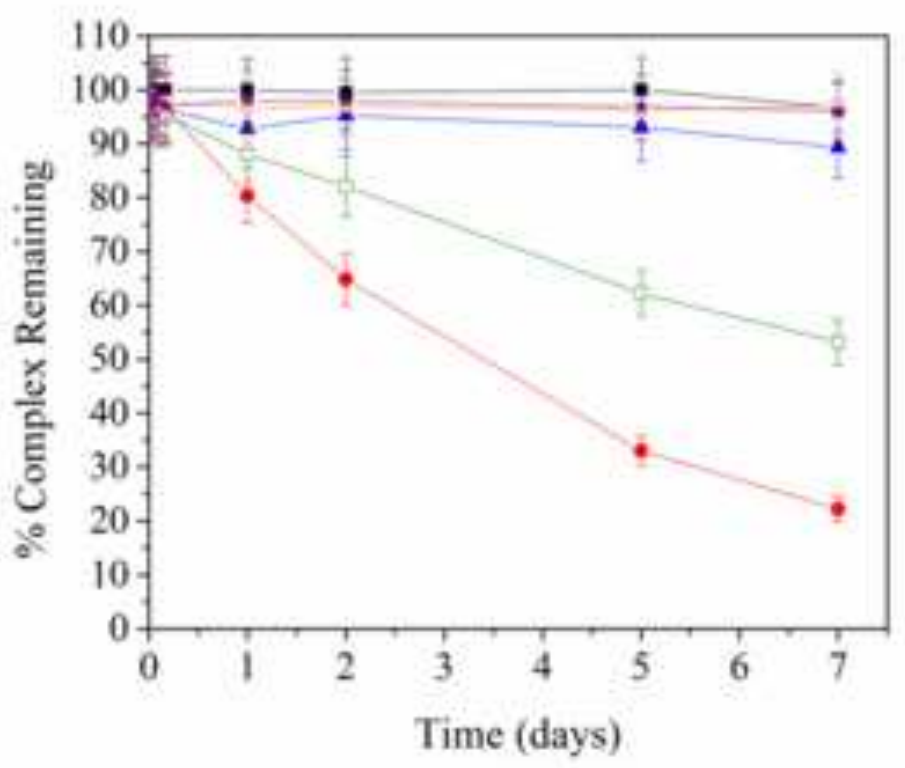

(b)

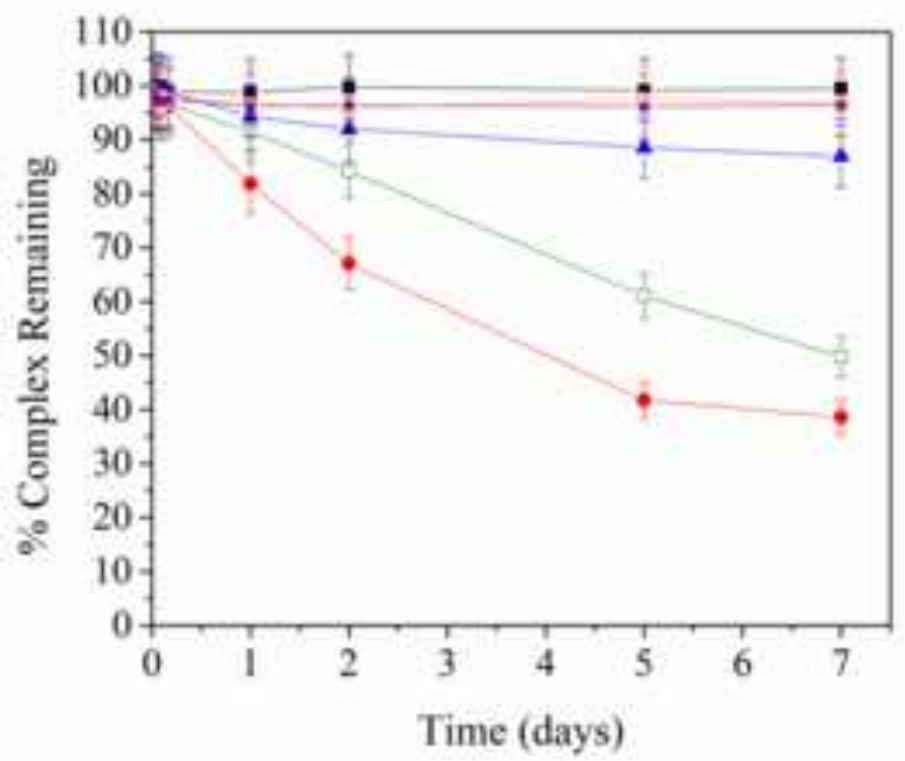

(d) 


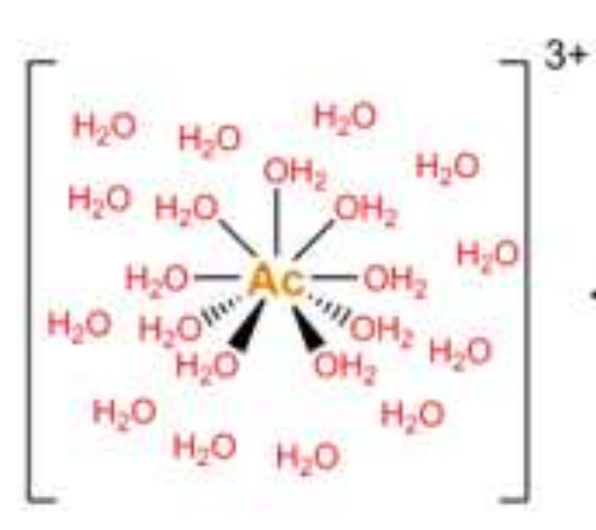

$\left[\mathrm{Ac}\left(\mathrm{OH}_{2}\right)_{9}\right]\left(\mathrm{H}_{2} \mathrm{O}\right)_{12}{ }^{+3}$
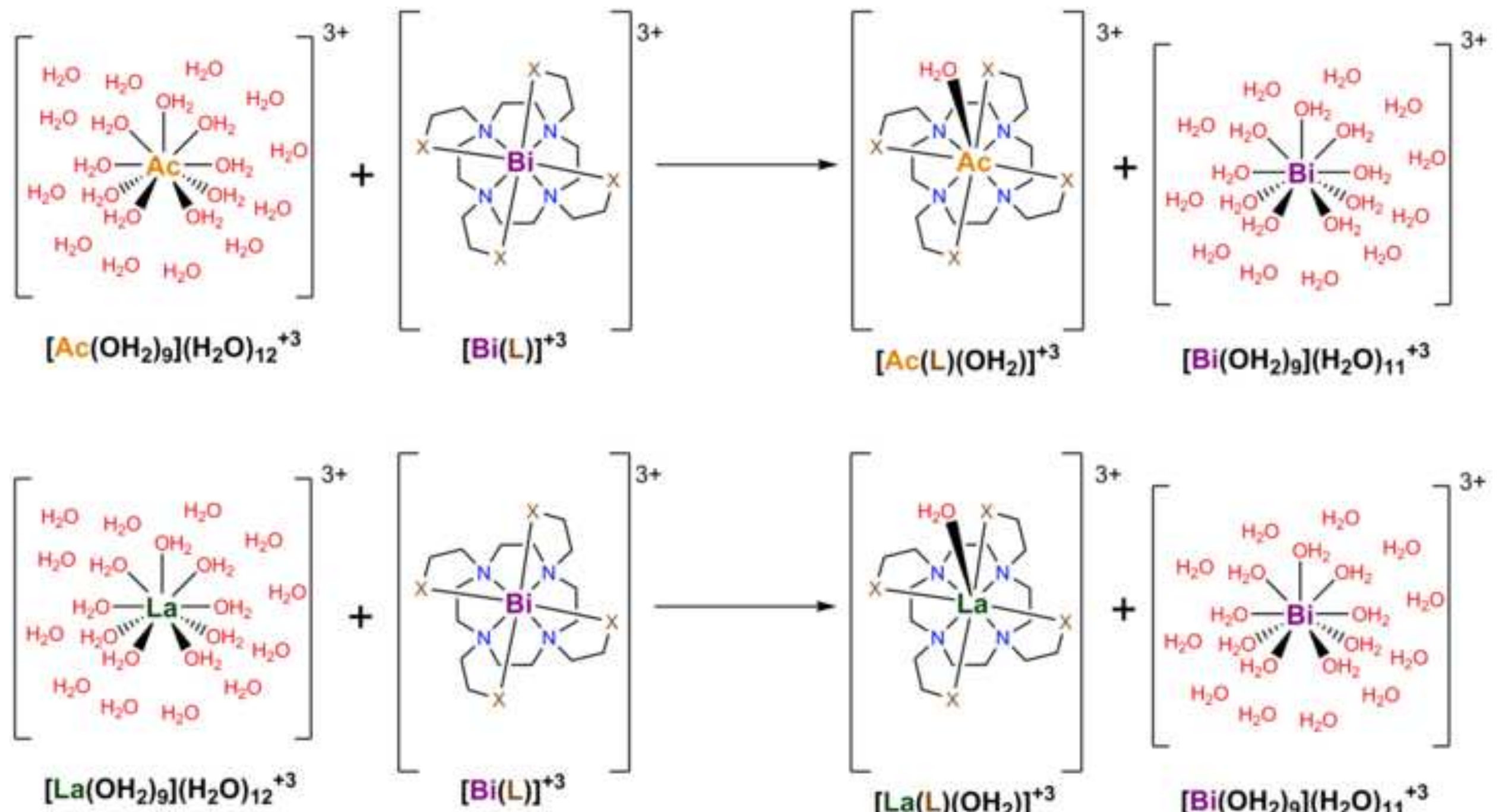

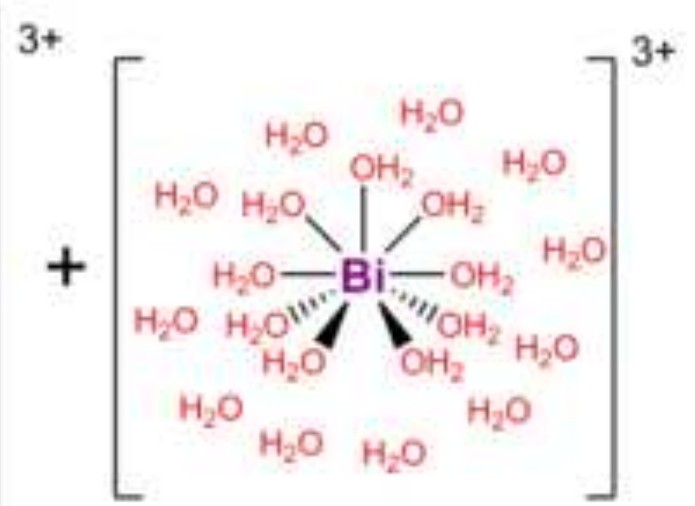

$\left[\mathrm{Bi}\left(\mathrm{OH}_{2}\right)_{9}\right]\left(\mathrm{H}_{2} \mathrm{O}\right)_{11}{ }^{+3}$

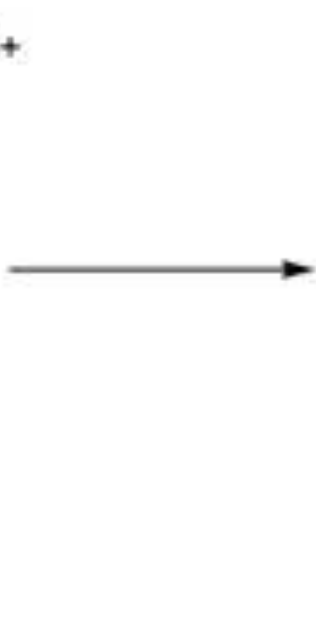

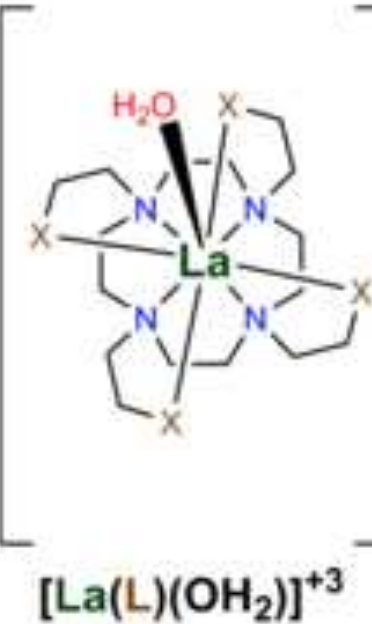

\section{$\left[\mathrm{La}\left(\mathrm{OH}_{2}\right)_{9}\right]\left(\mathrm{H}_{2} \mathrm{O}\right)_{12}{ }^{+3}$}



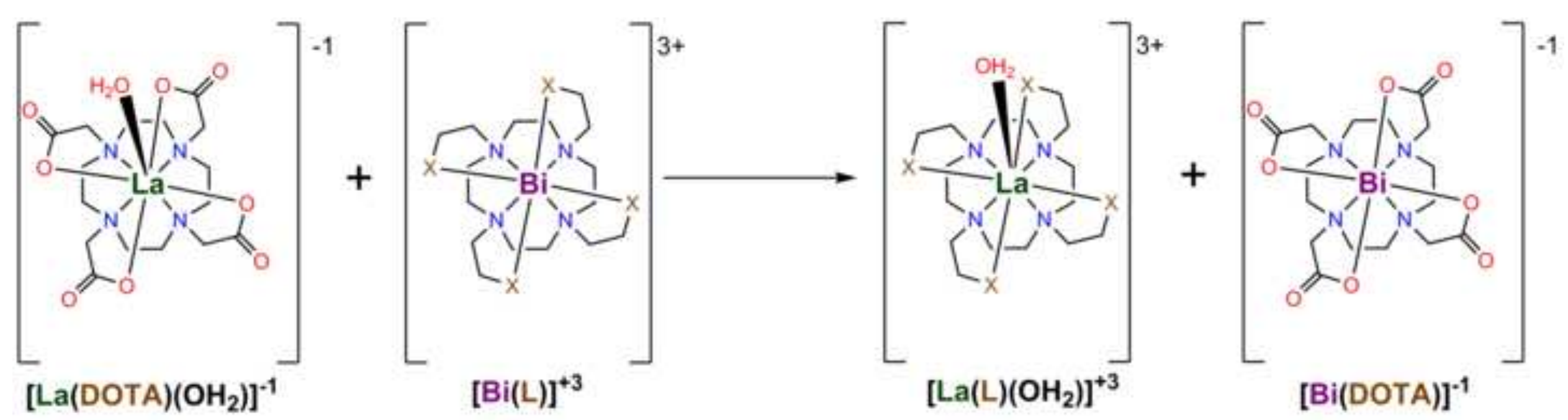

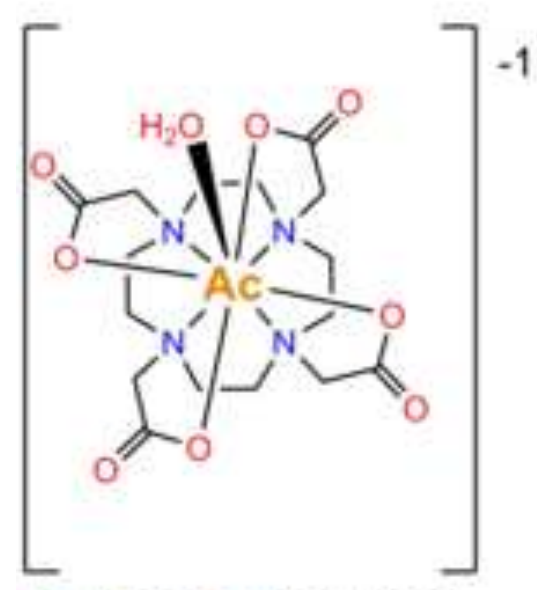

[Ac(DOTA) $\left.\left(\mathrm{OH}_{2}\right)\right]^{-1}$

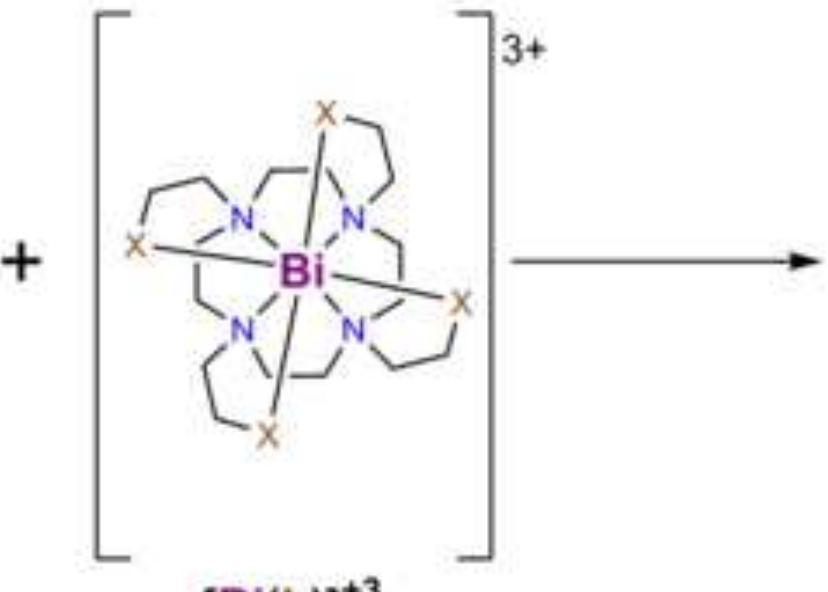

$[\mathrm{Bi}(\mathrm{L})]^{+3}$
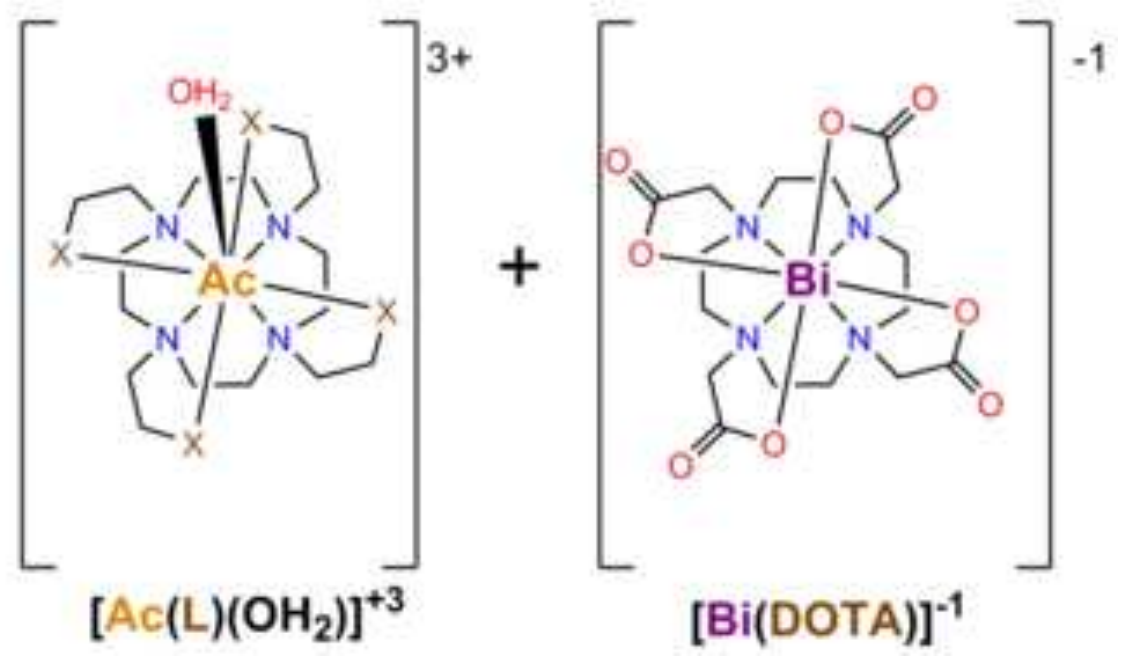